\title{
EFEITO DE TEORES E FONTES DE PROTEÍNA SOBRE O DESEMPENHO DE VACAS DE LEITE E DIGESTIBILIDADE DOS NUTRIENTES
}

\author{
MARIA TERESA GUIDI \\ ZOOTECNISTA
}

Orientador: Prof. Dr. FLÁVIO AUGUSTO PORTELA SANTOS

Dissertação apresentada à Escola Superior de Agricultura "Luiz de Queiroz", Universidade de São Paulo, para obtenção do título de mestre em Agronomia, Área de Concentração: Ciência Animal e Pastagens.

\author{
PIRACICABA \\ Estado de São Paulo - Brasil \\ Março - 1999
}


Dados Internacionais de Catalogação na Publicação (CIP)

DIVISĀO DE BIBLIOTECA E DOCUMENTAÇĀO - Campus "Luiz de Queiroz"/USP

Guidi, Maria Teresa

Efeito de teores e fontes de proteina sobre o desempenho de vacas de leite e digestibilidade dos nutrientes / Maria Teresa Guidi. - Piracicaba, 1999.

92 p.

Dissertação (mestrado) -. Escola Superior de Agricultura Luiz de Queiroz, 1999. Bibliografia.

1. Desempenho animal 2. Dieta animal 3. Digestibilidade 4. Exigència nutricional 5. Metabolismo animal 6. Produção leiteira 7. Proteina vegetal 8 . Vaca leiteira I.

Titulo

CDD 636.214

Termitida a cópla to tal ou parcial deste documento, desde que citada 0 fonte 0 Autor? 
"Ainda que eu falasse línguas, as dos homens e as dos anjos, seria como um bronze que soa ou como um cimbalo que tine.

Ainda que eu tivesse o dom da profecia, o conhecimento de todos os mistérios e de toda a ciência, ainda que tivesse toda a fé, a ponto de transportar montanhas, se não tivesse o amor, eu nada seria. Ainda que eu distribuísse todos os meus bens aos famintos, ainda que entregasse o meu corpo às chamas, se não tivesse amor isso nada me adiantaria.

O amor é paciente, o amor é prestativo, não é invejoso, não se ostenta, não se incha de orgulho.

Nada faz de inconveniente, não procura o seu próprio interesse, não se irrita, não guarda rancor.

Não se alegra com a injustiça, mas se regozija com a verdade.

Tudo desculpa, tudo crê, tudo espera, tudo suporta.

O amor jamais passará.

Quanto às profecias, desaparecerão.

Quanto às línguas, cessarão.

Quanto à ciência, também desaparecerá.

Pois o nosso conhecimento é limitado, e limitada é a nossa profecia. ” 


\section{OFEREÇO}

Aos meus pais

Jenny de Souza Guidi e José Guidi

À minha irmã e cunhado

Eva Maria Guidi Pinotti e Ricardo Pinotti

E aos meus sobrinhos

Samuel Guidi Pinotti, Rafael Guidi Pinotti e Tiago Guidi Pinotti

A Renato Gonçalves Ferreira DEDICO 


\section{AGRADECIMENTOS}

Ao curso de pós graduação de Ciência Animal e Pastagens da ESALQ/USP pela oportunidade oferecida.

Ao CNPq pela concessão de bolsa de estudo e à FAPESP pelo financiamento do experimento.

Aos professores Dr. Flávio Augusto Portela Santos pela orientação, Dr. José Manuel de Correia Simas pela atenção e ensinamentos e Dr. Alexandre Vaz Pires pela colaboração na execução do experimento.

A Sul Mineira Alimentos S/A, Três Coraçōes/MG e Cargill Agricola S/A, Uberlândia/MG pelo fornecimento de milho floculado, soja tostada e farelo de glúten de milho.

A todos os estagiários do CEPENA, os quais contribuíram para a concretização deste experimento, especialmente Adriano Barrichello, Elder José de Mello Bruno, Leo Vainzof, Miguel da Rocha Cavalcanti, Miguel Menezes, Ricardo Crestana e Rodrigo Brolo, os quais persistiram com responsabilidade, dedicação e companheirismo.

Aos amigos do grupo CEPENA, Cláudio Vaz Di Mambro Ribeiro e Mário Procópio de Menezes Júnior pela valiosa ajuda durante a condução do experimento e análises laboratoriais e Maria Cláudia Araripe Sucupira, Paulo Stacchini e Soraia Vanessa Matarazzo pela colaboração, solidariedade e incentivo.

Ao técnico de laboratório Carlos César Alves pela segura e divertida orientação na condução das análises laboratoriais, à secretária Cleide Martins pela constante atenção e todos os demais funcionários do setor de zootecnia de ruminantes que contribuiram para a realização deste trabalho.

A todos os colegas da pós graduação pela convivência agradável durante todo o mestrado e em especial aos colegas Hugo Imaizumi pelos "socorros" eletrônicos, Éberson de Castilho Barnabé pela colaboração no trabalho de campo e Michele Nazaré Chavier da Costa pela acolhida. 


\section{SUMÁRIO}

Página

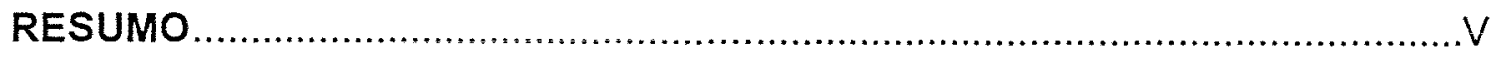

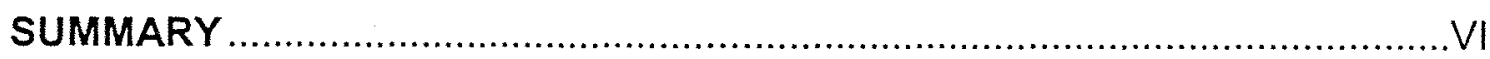

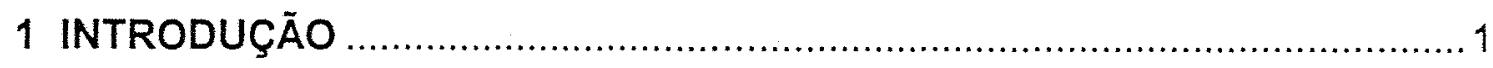

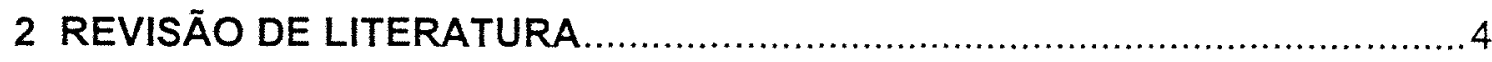

2.1 Degradação ruminal da proteína ................................................ 4

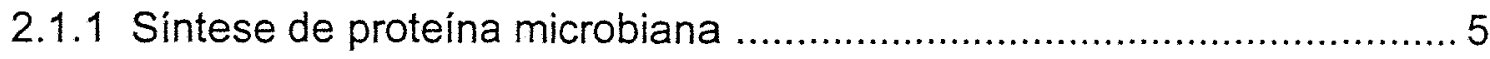

2.1.2 Passagem de proteína para o intestino delgado ............................. 7

2.1.3 Sincronização ruminal entre proteina e energia ................................. 8

2.1.4 Processamento de grãos .............................................................. 9

2.1.5 Degradação intestinal de proteina ................................................. 9

2.1.6 Absorção de AA no intestino delgado .............................................. 10

2.2 Fontes de proteína ................................................................................. 11

2.2.1 Qualidade da fonte de proteína ...................................................... 11

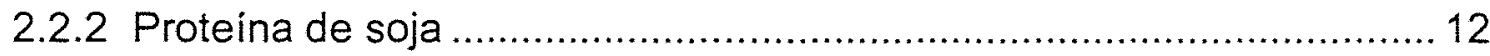

2.2.2.1 Efeitos da tostagem da soja grão ............................................ 13

2.2.3 Farelo de glúten de milho ....................................................... 14

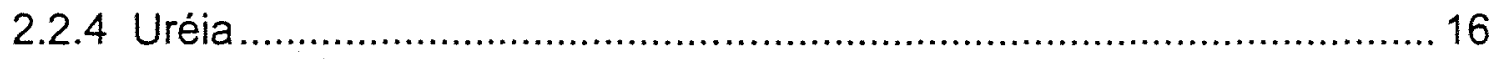

2.3 Efeito de fonte protéica .............................................................. 16

2.3.1 Ingestão de matéria seca .......................................................... 16

2.3.1.1 Comparação entre farelo de soja e soja tostada ............................ 16

2.3.1.2 Comparação entre farelo de soja e farelo de glúten de milho........... 16

2.3.1.3 Comparação entre farelo de soja e uréia ..................................... 17

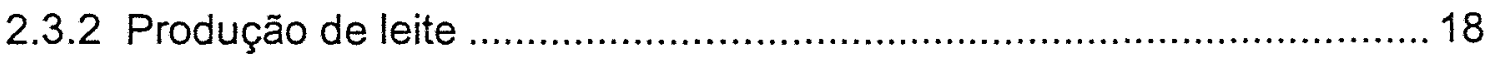

2.3.2.1 Comparação entre farelo de soja e soja tostada............................ 18

2.3.2.2 Comparação entre farelo de soja e farelo de glúten de milho........... 19

2.3.2.3 Comparação entre farelo de soja e uréia ....................................... 20

2.3.3 Composição do leite ..................................................................... 22

2.3.3.1 Comparação entre farelo de soja e soja tostada............................ 22 
2.3.3.2 Comparação entre farelo de soja e farelo de glúten de milho........... 23

2.3.3.3 Comparação entre farelo de soja e uréia ..................................... 24

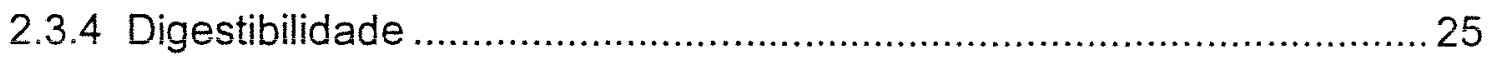

2.3.4.1 Comparação entre farelo de soja e soja tostada.......................... 25

2.3.4.2 Comparação entre farelo de soja e farelo de glúten de milho ........... 25

2.3.4.3 Comparação entre farelo de soja e uréia ....................................... 26

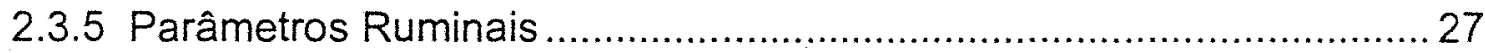

2.3.5.1 Comparação entre farelo de soja e soja tostada........................... 27

2.3.5.2 Comparação entre farelo de soja e farelo de glúten de milho .......... 27

2.3.5.3 Comparação entre farelo de soja e uréia .......................................... 28

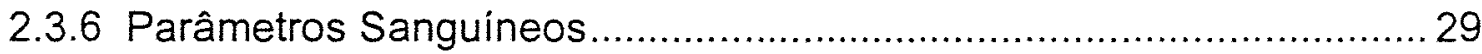

2.3.6.1 Comparação entre farelo de soja e soja tostada............................. 30

2.3.6.2 Comparação entre farelo de soja e farelo de glúten de milho ........... 30

2.3.6.3 Comparação entre farelo de soja e uréia ........................................ 31

2.4 Justificativas para a hipótese de trabalho ....................................... 31

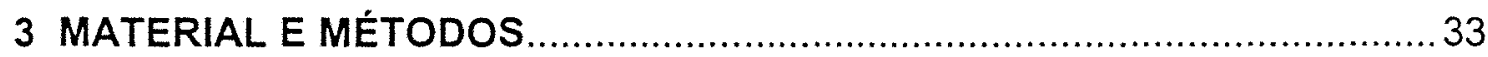

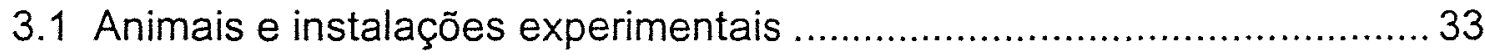

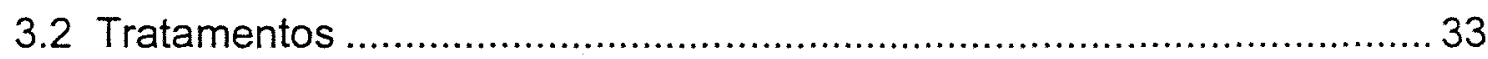

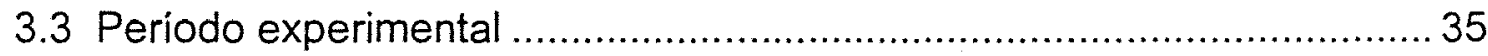

3.3.1 Administração de óxido de cromo (marcador externo) ........................ 35

3.3.2 Pesagem e amostragem do alimento oferecido e residuo alimentar ... 35

3.3.3 Pesagem e amostragem de leite .................................................. 36

3.3.4 Coleta de bolo alimentar do duodeno .......................................... 36

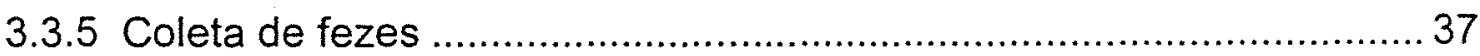

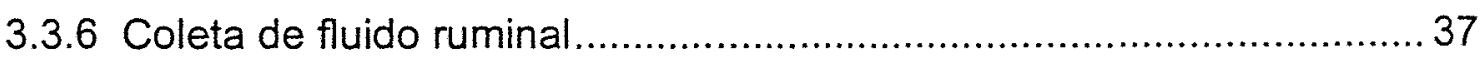

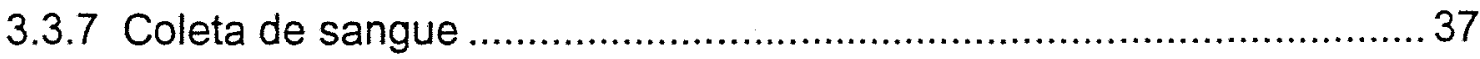

3.4 Preparo das amostras e análises laboratoriais .................................. 38

3.4.1 Análise da concentração de cromo ...................................................38

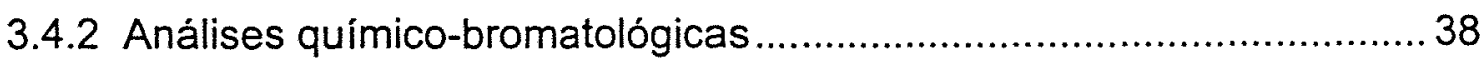

3.4.3 Análise de glucose e uréia plasmática ............................................39 
3.4.4 Análise de amônia e AGV no fluido ruminal ..................................... 39

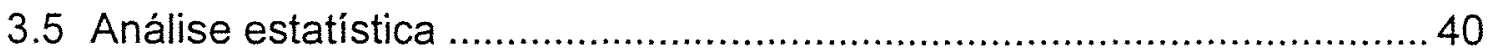

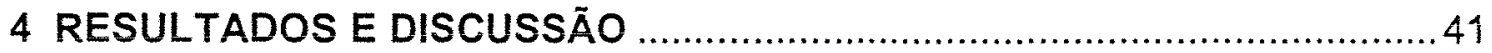

4.1 Composição químico-bromatológica das dietas experimentais.............. 41

4.2 Digestibilidade dos nutrientes no trato total....................................... 42

4.2.1 Digestibilidade da MS ......................................................... 43

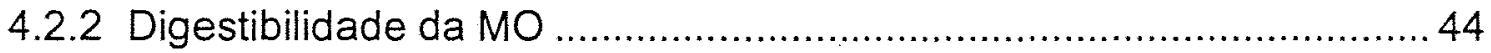

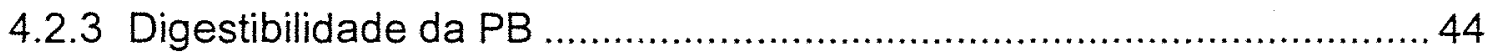

4.2.4 Digestibilidade do Amido ......................................................... 45

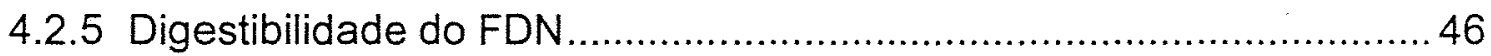

4.3 Ingestão de MS, produção e composição do leite................................. 46

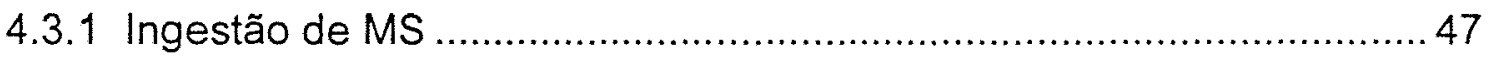

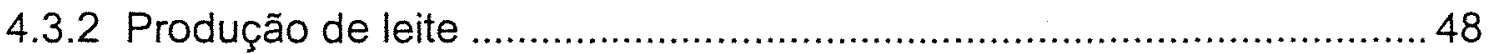

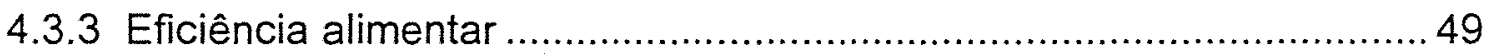

4.3.4 Composição do leite ................................................................... 49

4.3.4.1 Proteína do leite ..................................................................... 49

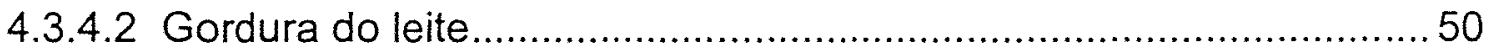

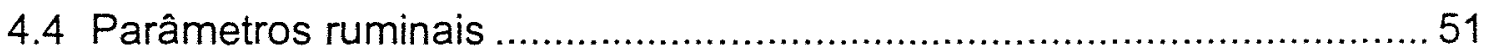

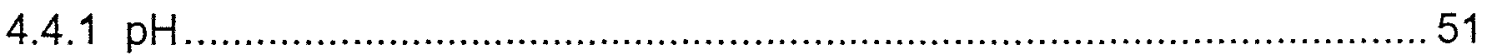

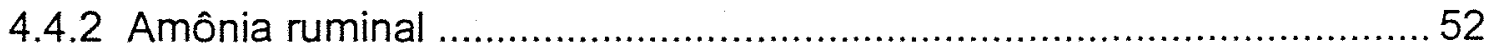

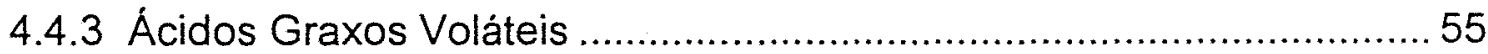

4.4.3.1 Concentração de AGV total.......................................................... 55

4.4.3.2 Porcentagem molar de acetato ..................................................5 57

4.4.3.3 Porcentagem molar de propionato ............................................ 59

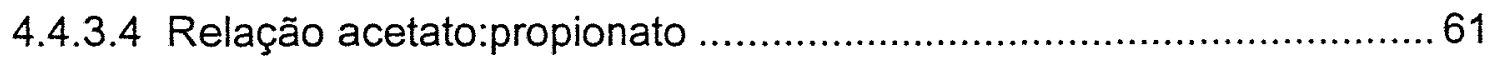

4.4.3.5 Porcentagem molar de butirato ................................................ 63

4.4.3.6 Porcentagem molar de AGV de cadeia ramificada .........................64 64

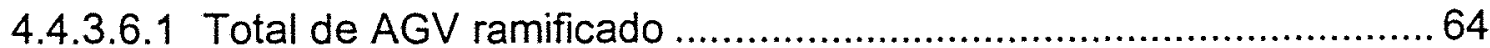

4.4.3.6.2 Porcentagem molar de isobutirato, isovalerato e valerato .............66 66

4.4.4 Parâmetros sanguineos ................................................................. 70 
4.4.4.1 Concentração de uréia plasmática ............................................70

4.4.4.2 Concentração de glucose plasmática.......................................... 72

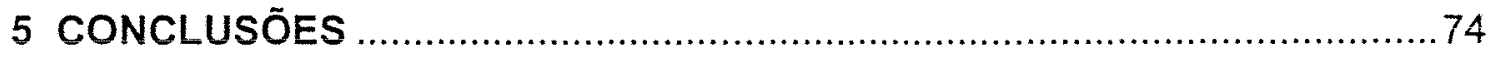

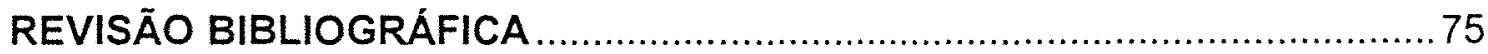




\title{
EFEITO DE TEORES E FONTES DE PROTEINA SOBRE O DESEMPENHO DE VACAS DE LEITE E DIGESTIBILIDADE DOS NUTRIENTES
}

\author{
Autora: MARIA TERESA GUIDI \\ Orientador: Prof. Dr. FLÁVIO AUGUSTO PORTELA SANTOS
}

\section{RESUMO}

Foram utilizadas cinco vacas holandesas canuladas no rúmen $e$ duodeno, com produções de leite em torno de $30 \mathrm{~kg} / \mathrm{d}$, num delineamento do tipo Quadrado Latino 5X5. As dietas continham silagem de milho, milho floculado, caroço de algodão e mistura mineral e vitaminica e foram formuladas variando teores e fontes de proteína, constituindo-se em cinco tratamentos: controle, uréia, farelo de soja, soja tostada e farelo de glúten de milho. A dieta controle continha $13,4 \%$ de proteína bruta na matéria seca e as demais ao redor de $16,5 \%$. O teor e a fonte de proteina não afetaram a ingestão de matéria seca, a produção de leite, a porcentagem e a produção de gordura do leite e a eficiência alimentar. A suplementação de soja tostada teve efeito negativo na porcentagem de proteina do leite. As digestibilidades da matéria seca, da matéria orgânica, do amido e da fibra em detergente neutro no trato total, não foram afetados pelos tratamentos, mas o tratamento controle e soja tostada diminuiram a digestibilidade da proteina bruta. A suplementação de uréia aumentou a concentração de amônia no rúmen e de uréia no plasma, enquanto que o pH ruminal, a produção de ácidos graxos voláteis e a concentração plasmática de glucose não foram afetadas pelos tratamentos. 


\title{
EFFECT OF PROTEIN LEVELS AND SOURCES ON PERFORMANCE AND NUTRIENT UTILIZATION BY LACTATING DAIRY COWS
}

\author{
Author: MARIA TERESA GUIDI \\ Adviser: Prof. Dr. FLÁVIO AUGUSTO PORTELA SANTOS
}

\section{SUMMARY}

Five rumen and duodenaly canulated dairy cows were utilized in a $5 \times 5$ L.S. design. Diets were based on corn silage, steam-flaked corn, whole cotton seed, protein supplement and mineral and vitamins. Different protein supplements were used, resulting in five treatments: control, urea, soybean meal, roasted soybeans and corn gluten meal. The control diet was $13.49 \%$ crude protein and the other diets were around $16.5 \%$. The dry matter intake, milk production, milk fat content and yield and feed efficiency were not affected by protein level and sources. The milk protein content was decreased by feeding roasted soybean. The treatments had no effect on the total tract digestibilities of dry matter, organic matter, starch and neutral detergent fiber, but crude protein digestibility was lower in the control and roasted soybeans diets. Feeding urea increased both, rumen ammonia $\mathrm{N}$ and plasma urea-N. The treatments had no effect on rumen $\mathrm{pH}$, volatile fatty acids production and plasma glucose concentration. 


\section{INTRODUÇÃO}

$\mathrm{Na}$ exploração de gado de leite, os gastos com alimentação geralmente representam $50-60 \%$ do custo total de produção, sendo normalmente as fontes protéicas as mais onerosas e sua limitação ou excesso podem afetar seriamente a produção e a saúde do rebanho (Chandler, 1989).

O ruminante apresenta características peculiares em relação à suplementação protéica e a proteína que chega ao intestino delgado (ID) é composta por proteina endógena, proteina microbiana ( $P M)$ e proteína da dieta que escapa da degradação ruminal.

Virtanen (1966) provou que o rúmen, através da síntese de PM utilizando uréia como única fonte nitrogenada, era capaz de suprir as exigências protéicas de vacas com produções em torno de $4.500 \mathrm{~kg}$ de leite/ano. Entretanto, atualmente é comum em paises de pecuária leiteira intensiva, rebanhos com média de 9.000 a $14.000 \mathrm{~kg}$ de leite/vaca/ano. Parte desse progresso se deve a avanços simultâneos de grande impacto também na área de manejo nutricional de vacas de leite. O NRC (1985) propôs um modelo de proteína absorvida, onde a exigência protéica do animal foi dividida em proteína degradável no rúmen ( $P D R$ ), que deve suprir as exigências dos microrganismos e proteina não degradável no rúmen (PNDR), que deve complementar a PM que chega ao intestino.

A produção de leite, no que se refere às exigências protéicas, é atendida pela PM e PNDR que chegam ao intestino delgado (ID). Portanto, para aumentar o aporte de aminoácidos essenciais (AAE) para o ID, tem-se que maximizar a síntese de PM e, se necessário, complementar com PNDR. A 
proporção que cada fração protéica representa no intestino delgado é dependente de vários fatores, dentre eles, o teor de ingestão de matéria seca (MS), o sincronismo entre fontes de carboidrato e de proteina e o teor de PNDR da dieta.

Na década de 70 a 80 , estudos conduzidos "in vitro" sugeriram que a sintese de PM seria maximizada com teores de 2 a $5 \mathrm{mg} / \mathrm{dl}$ de amônia ruminal (Satter \& Slytter, 1974) e efeitos positivos sobre a produção de leite e teor da proteina do leite foram reportados em pesquisas onde a caseina (proteina do leite) foi infundida no abomaso ou ID de vacas de leite, escapando assim da degradação ruminal (Clark, 1975). Estes resultados levaram diversos pesquisadores a propor que a suplementação de proteína resistente à degradação ruminal aumentaria a quantidade de proteína e AAE que chegam ao ID, resultando em aumentos consideráveis no desempenho de vacas de leite de alta produção.

A utilização de suplementos protéicos ricos em PNDR em dieta de vacas de leite tornou-se comum na América do Norte, mas o beneficio da utilização destas fontes tem sido questionado recentemente, uma vez que na maioria dos trabalhos de metabolismo não houve aumento no fluxo de AAE para o ID e nos experimentos de produção; em $82 \%$ dos casos os animais alimentados com fontes de proteina ricas em PNDR não responderam com aumento de produção de leite comparado aos que receberam farelo de soja (Santos, 1996; Santos \& Huber, 1996).

O teor e o perfil dos AAE da PNDR são determinantes para o sucesso da inclusão destas fontes em dietas de vacas de leite (Chen et al., 1993; Clark et al., 1992; Schwab, 1994; Santos \& Huber, 1996). Os AAE considerados mais limitantes para a produção de proteina do leite são a lisina (Lis) e a metionina (Met) (King et al., 1990; Schwab et al., 1992a e 1992b). Tem sido recomendado que, para maximizar a síntese de proteina de leite, os teores de Lis e de Met deveriam estar, respectivamente, ao redor de 15 e $5 \%$ do total de AAE do bolo alimentar que chega ao duodeno (Schwab et al., 1992a e 1992b). Fontes de 
PNDR baixas ou deficientes em Lis e Met podem diminuir ou não afetar a produção e o teor de proteína do leite (Schwab, 1994; Santos \& Huber, 1996).

A sincronização da degradação ruminal de proteína e energia em vacas de alta produção é de extrema importância, objetivando-se maximizar a síntese de PM e o fluxo de AAE para o intestino (Santos \& Huber, 1996).

Portanto, é necessária a realização de pesquisas de metabolismo com vacas de leite de alta produção para a identificação de combinações de fontes protéicas e energéticas, que sincronizem a disponibilidade ruminal de energia e de $\mathrm{N}$ para otimizar a síntese de PM e o fluxo de nutrientes para o ID. 


\section{REVISÃO DE LITERATURA}

\subsection{Degradação ruminal da proteína}

De acordo com o NRC (1985) a proteína ingerida pode passar para o omaso sem sofrer ação dos microrganismos ou ser degradada no rúmen, onde as ligações peptídicas são hidrolisadas (proteólise) e os peptídeos e aminoácidos (AA) liberados são utilizados para a sintese de PM ou deaminados, produzindo amônia que pode ser utilizada pelos microrganismos e ácidos graxos voláteis (AGV) absorvidos através da parede ruminal. A porção protéica também pode ser subdividida em três frações: a fração $A$ é composta por nitrogênio não protéico (NNP) e proteína degradada muito rapidamente no rúmen; a fração $B$ é degradada lentamente e dependente das taxas de degradação e de passagem no rúmen; e a fração $C$, que é indisponivel para 0 ruminante. Portanto, a PNDR é composta por parte da fração $B$, que escapa do ataque microbiano no rúmen e pela fração $\mathrm{C}$.

A extensão de degradação da proteina no rúmen é variável entre os ingredientes da dieta e depende do tempo de retenção no rúmen, o qual diminui com a redução do tamanho da partícula, com o aumento da quantidade de alimento ingerido (de forma direta, aumentando a taxa de passagem e indireta, reduzindo $\circ \mathrm{pH}$ ruminal, a atividade bacteriana e proteolítica, a degradação da fibra e o acesso dos microrganismos às proteínas das plantas) e com o abaixamento da temperatura ambiente. A taxa de degradação, intrinseca a cada alimento, também pode ser alterada pelos métodos de processamento, tais como peletização, extrusão, laminação, floculação e tostagem (NRC 1985). 


\subsubsection{Síntese de proteína microbiana}

O requerimento bacteriano de nutrientes é uma função das exigências de mantença e de crescimento dos microrganismos. Quanto maiores os custos para mantença, menor a síntese de novos microrganismos, ocorrendo em parte devido ao desacoplamento energético, que pode ser influenciado pelo desbalanceamento de nutrientes e condições ambientais do rúmen. Os microrganismos diferem qualitativamente quanto ao seus requerimentos para a sintese de proteina. Os fermentadores de fibra requerem amônia como fonte de nitrogênio $(N)$ e podem requerer AGV de cadeia ramificada. Os fermentadores de açúcar, amido e produtos secundários requerem amônia, mas principalmente AA e peptídeos, como fonte de $N$ (Russel et al., 1992).

A quantidade de amônia requerida para o crescimento microbiano é discutivel. Mehrez et al. (1977), citado pelo NRC (1985), sugeriram que uma concentração de amônia de 20 a $22 \mathrm{mg} \mathrm{N}-\mathrm{NH}_{3} / 100 \mathrm{ml}$ de fluido ruminal seria necessária para maximizar a taxa de fermentação da MS de cevada. Valores bem inferiores (2 a $3 \mathrm{mg} / 100 \mathrm{ml}$ ) para maximizar as taxas de crescimento foram preconizados por Satter \& Slyter (1974), baseando-se em dados "in vitro" com dietas fibrosas.

O requerimento real de amônia pode estar diretamente correlacionado à disponibilidade do substrato, à taxa de fermentação, à massa microbiana e à produção animal. Devido à grande quantidade de matéria orgânica (MO) fermentável presente em dietas de vacas de leite, Poos et al. (1979a), citado pelo NRC (1985), sugeriram que a maximização da digestão e ingestão dependem de concentrações de amônia mais elevadas que as propostas por Satter \& Slyter (1974).

O crescimento microbiano e o fluxo microbiano para o ID podem ser afetados pela ingestão de alimento, relação forragem:concentrado, fontes e quantidade de carboidratos não estruturais, de PB e de gordura na dieta, 
frequência alimentar, processamento de forragens e grãos, métodos de conservação de forragens, suplementação de micronutrientes, tamponantes alimentares, sais, ionóforos e condições ambientais (Sniffen \& Robinson, 1987).

A ingestão de matéria seca (MS) influencia a sintese microbiana de forma direta, afetando a quantidade e o tipo de substrato disponivel e indireta, alterando os parâmetros ruminais ( $\mathrm{pH}$ e taxa de passagem). A maior proporção de forragem aumenta a eficiência de sintese microbiana, provavelmente por aumentar o fluxo de saliva e a renovação de liquido, favorecendo a lavagem de bactérias acopladas à pequenas partículas, $\circ \mathrm{pH}$ e $\mathrm{O}$ ambiente ruminal. Os custos totais de mantença são reduzidos e os microrganismos velhos são lavados, promovendo assim a formação de uma população mais jovem (NRC, 1985).

De acordo com Clark et al. (1992) a quantidade e a fonte de carboidrato não estrutural (CNE) da dieta afetaram a síntese de PM. Dietas com menores proporções de CNE e PDR deprimiram a concentração de amônia, a digestão da $\mathrm{MO}$ e dos CNE no rúmen, resultando em menor passagem de PM para o ID. $A$ adição de lipideos na dieta não afetou o fluxo de PM para o ID, mas aumentou a eficiência de síntese de PM, provavelmente por deprimir o número de protozoários do fluido ruminal, reduzindo a predação das bactérias. A quantidade de $\mathrm{PB}$ da dieta afetou significativamente a passagem de proteína verdadeira para o ID e a concentração de amônia ruminal, mas não apresentou alta relação com a passagem de PM para o ID; porém, suplementos protéicos com baixa degradação ruminal (participando de 14 a $65 \%$ do total da PB da dieta) diminuíram a passagem de PM para o ID quando comparados com 0 farelo de soja. Os autores sugeriram que o crescimento microbiano e a eficiência de fermentação ruminal poderiam ter sido aumentados devido ao excedente de energia e AA provenientes da proteína da soja e à maior ingestão de MS do tratamento farelo de soja, concluindo que dietas com concentrações de amônia ruminal superiores a $5 \mathrm{mg} / \mathrm{dl}$ apresentam passagem de PM para 0 ID altamente correlacionada com a MO verdadeiramente digerida no rúmen. 


\subsubsection{Passagem de proteína para o intestino delgado}

Devido às diversas interações do $N$ no rúmen, a ingestão de proteína não é um bom indicador para predizer o fluxo de $N$ para o ID (NRC, 1985). Trinta a cinquenta porcento do fluxo total de amônia pode ser reciclado dentro do rúmen, como também via hospedeiro através da parede do rúmen e saliva, podendo esta última ser quantitativamente importante, principalmente em animais com altas taxas de passagem, quando a saida de PM é maior do que a ingestão de PDR. Isto se torna muito aparente quando a proteína da dieta apresenta pequena proporção de fração $A$, baixa taxa de degradação da fração $\mathrm{B}$ e a fração $\mathrm{C}$ é significativa.

De acordo com o NRC (1985) o principal determinante da quantidade de $N$ que entra no ID é a energia consumida e os mesmos fatores que afetam a degradação ruminal de proteína e produção de PM eventualmente afetam o fluxo de $N$ duodenal. Considerando que o $N$ que entra no duodeno é proveniente de uma combinação entre PM, PNDR e proteína endógena, a composição de AA destas fontes e a proporção de cada uma delas na proteína total que chega ao intestino determinam a quantidade e perfil de $A A$ que chegam ao intestino para serem absorvidos.

Vários trabalhos de metabolismo avaliaram o efeito da substituição parcial ou total de uma fonte protéica alta em PDR (farelo de soja) por fontes ricas em PNDR. De acordo com Santos (1996), em 17 comparações realizadas, o fluxo de PM para o ID foi afetado negativamente em 7 comparações, o fluxo de PNDR aumentou em 7 e a proteína total (PM+PNDR) aumentou em apenas duas comparações. A carência de efeito sobre o fluxo de proteína total se deve provavelmente ao fato do aumento no fluxo de PNDR não compensar a diminuição no fluxo de PM. O fluxo de AAE para O ID foi avaliado em 16 comparações, ocorrendo aumento significativo em apenas 4 comparações avaliadas. O fluxo de Lis e Met foi avaliado em 17 comparações, ocorrendo 
aumento no fluxo de Lis em duas e diminuição em uma comparação. $O$ aumento no fluxo de Lis ocorreu com a utilização de fontes protéicas ricas neste $A A$, como farinha de sangue e farinha de peixe, e a diminuição ocorreu com o uso de suplemento pobre em Lis, como farelo de glúten de milho. O fluxo de Met aumentou em uma comparação, quando a farinha de peixe foi utilizada e diminuiu em uma comparação, com o uso de soja grão extrusada a $149^{\circ} \mathrm{C}$. Portanto, a quantidade e o balanço de AAE do bolo alimentar podem ser alterados pela participação da PM e da PNDR na proteína total que chega ao intestino.

\subsubsection{Sincronização ruminal entre proteína e energia}

De acordo com o Santos et al. (1998), a sincronização da degradação ruminal de proteina e energia em vacas de alta produção é de extrema importância. Uma adequada suplementação de PDR é essencial tanto para a digestibilidade ruminal, como para a ingestão de alimento e teores de amônia ruminal maiores que 8 a $15 \mathrm{mg}$ de $\mathrm{N} / \mathrm{dl}$ podem ser requeridos para maximizar a digestão da $M O$ no rúmen de vacas lactantes. A adição de adequada quantidade de PDR em dietas contendo silagem de milho de alta energia fermentável proporcionou aumento no fluxo de $\mathrm{N}$ duodenal, na digestibilidade aparente da MS, na concentração de EL da dieta e na produção de leite e diminuição nas perdas de peso (NRC, 1988).

Casper et al. (1990) concluíram que a síntese de PM no rúmen e a eficiência de utilização da PDR podem ser maximizadas variando a fonte e a degradabilidade de carboidrato não estrutural (CNE) em dietas de vacas de leite. A taxa de degradação ruminal da fonte energética é o principal fator limitante para a utilização de NNP. Casper \& Schingoethe (1986) obtiveram similares produções de leite quando forneceram farelo de soja ou uma combinação de farelo de soja e uréia em dietas contendo $30 \%$ de soro seco, uma fonte de CNE rapidamente fermentável no rúmen. 


\subsubsection{Processamento de grãos}

De acordo com Simas (1997), o amido representa cerca de 60 a $80 \%$ da matéria seca dos grãos de cereais e é a principal fonte de energia em dietas para vacas de leite. A taxa e extensão de digestão do amido no rúmen influenciam a produção e a proporção de $A G V$, o pH do rúmen e a quantidade $e$ a forma física e química do amido disponivel para digestão pós ruminal. Portanto, processamentos de grãos que melhorem a taxa e extensão de digestão do amido podem aumentar a eficiência de utilização deste nutriente e o desempenho de vacas leiteiras de alta produção, provavelmente por aumentar a absorção de energia e proteína. O processo de floculação envolve movimento de água e calor para o interior do grão, promovendo a gelatinização do amido, tornado-o mais susceptivel à ação dos microrganismos do rúmen e das enzimas que atuam no ID dos ruminantes. O grão é submetido ao vapor por 30 a 40 minutos atingindo a temperatura de $150^{\circ} \mathrm{C}$ e prensado em rolos, produzindo flocos de determinada espessura e densidade, as quais são inversamente proporcionais à degradabilidade do amido, sendo a densidade ótima para a floculação do milho e do sorgo em torno de $360 \mathrm{~g} / \mathrm{L}$ (Santos, 1996; Moore et al., 1992; Yu et al., 1994; Chen et al., 1995). Com a floculação, a digestibilidade do amido do milho no rúmen aumenta de $70 \%$ para $86 \%$ e no trato total de $91 \%$ para $99 \%$, aumentando a disponibilidade de energia fermentável no rúmen (Theurer, 1986).

\subsubsection{Degradação intestinal de proteína}

A digestão de proteína no abomaso e ID de ruminantes parece ser similar a de monogástricos, exceto pela baixa neutralização do bolo alimentar no ID e a abundância da ribonuclease pancreática. Essa baixa neutralização está associada ao baixo conteúdo de bicarbonato do suco pancreático, fazendo 
com que se estenda a atividade da pepsina abomasal e retarde a atividade das enzimas intestinais (tripsina, quimotripsina e carboxipeptidase). A abundante quantidade de RNAse pancreática é responsável pela liberação do fósforo do ácido nucléico, reciclando-o ao rúmen via saliva (NRC, 1985).

\subsubsection{Absorção de AA no intestino delgado}

Nos ovinos, a maior atividade de absorção de AA ocorre entre o illeo medial e distal, envolvendo gasto de energia, pois esta ocorre contra um gradiente de concentração. Ocorre um desaparecimento preferencial de AAE sobre AA não essenciais através do ID de ovinos e bovinos. A ordem de absorção dos diferentes AA é variável entre os trabalhos publicados, mas 0 efeito depressivo de leucina sob a absorção de lisina foi confirmado tanto "in vitro" como em "in vivo" (NRC, 1985).

Apesar do ID ser o principal órgão responsável pela absorção dos AA, alguns autores (Webb et al., 1992, 1993) baseando-se em resultados de fluxos sanguíneos mesentéricos (jejuno, íleo, ceco, colo e pâncreas) e não mesentéricos (rúmen, retículo, omaso, abomaso, duodeno e baço) sugeriram a importância da absorção de peptídeos nos pré estômagos, sendo demonstrado in vitro por Matthews \& Webb (1995) que os tecidos do rúmen e omaso absorvem peptídeos. Clark et al. (1992) questionaram a importância da absorção de peptídeos baseados nos resultados de fluxo de $\mathrm{N}$ para o duodeno de oito experimentos, onde a quantidade de peptideo e $A A$ absorvidos no rúmen e omaso representou menos de $7 \%$ do $\mathrm{N}$ ingerido, podendo, apenas em certas condições alimentares, chegar a $20 \%$.

De acordo com o NRC (1985), a absorção de N no ID pode ser afetada pelo teor de ingestão de alimento (por influenciar a taxa de passagem da digesta ou por alterar as proporções de PM e PNDR) e pelo estado fisiológico do animal (por aumentar a área absortiva e o fluxo sanguíneo para o intestino 
conforme o estado fisiológico), onde lactantes apresentam maior eficiência que prenhes e estas maior que as não prenhes e não lactantes.

Um dos principais aspectos que estimulou a suplementação de fontes ricas em PNDR para vacas de leite foi a hipótese de se ter uma maior disponibilidade de AAE para absorção no ID. Entretanto, o aumento de absorção de AAE com o uso de fontes protéicas ricas em PNDR não tem sido observado na maioria dos trabalhos de metabolismo (Windschitl \& Stern, 1988; Stern et al., 1985; Waltz et al., 1989; Mabjeesh et al., 1996).

\subsection{Fontes de proteína}

\subsubsection{Qualidade da fonte de proteína}

A qualidade da proteina (perfil de AAE) que chega ao ID desempenha importante papel sobre a produção de leite e sintese de proteina do leite (Schwab 1994, Schwab et al., 1992a; Schwab et al., 1992b). O perfil de AA da proteína do leite deve ser utilizado como referência para avaliar a qualidade da fonte protéica, pois $90 \%$ do requerimento protéico de vacas de alta produção é direcionado para produção de leite (Schingoethe, 1996).

Lis e Met são provavelmente o primeiro e segundo AA mais limitantes em dietas de vacas de alta produção (Schwab 1994, Schwab et al., 1992a; Schwab et al., 1992b; King et al., 1990). As proporções adequadas de Lis e Met em relação ao total de AAE do bolo alimentar que chega ao ID de vacas em lactação para maximizar a sintese de proteina do leite são, respectivamente, $15 \%$ e $5 \%$ (Schwab, 1994; Rulquin \& Verité, 1993). Portanto, suplementos baixos ou desbalanceados em Lis e Met devem resultar em beneficio nulo ou redução de produção de leite e proteína do leite (Schwab, 1994). 


\subsubsection{Proteína de soja}

A proteina da soja é de excelente qualidade, adequada em Lis mas deficiente em Met (Schwab et al., 1976).

O farelo de soja apresenta, em média $49,9 \%$ de PB, 1,94 Mcal $/ \mathrm{kg}$ de energia líquida da lactação $\left(E L_{L a c}\right)$, e $1,5 \%$ de extrato etéreo $(E E)$ e a soja grão tostada é rica tanto em proteína como em energia, contendo $42,2 \%$ de PB, 2,18 Mcal/kg de $E L_{\text {Lac }}$ e $20 \%$ de EE (NRC, 1988).

De acordo com o NRC (1988), a proteina do farelo de soja é rapidamente degradado pelos microrganismos do rúmen, apresentando valor de tabela em torno de $35 \%$ de PNDR. Robinson et al. (1991) sugeriram que a PNDR é variável conforme a taxa de passagem $(k p)$. Em dieta a base de silagem de milho, Cozzi \& Polan (1994) determinaram PNDR "in situ" do farelo de soja em torno de $46,9 \%$, assumindo uma $\mathrm{kp}$ de $8 \% / \mathrm{h}$ e $37,2 \%$ para uma $\mathrm{kp}$ de $5 \% / \mathrm{h}$. Estes dados indicam que o valor proposto pelo NRC de $35 \%$ pode estar subestimado para vacas de leite de alto potencial com consumo elevado de alimento.

A tostagem do grão de soja aumenta a quantidade de proteina que escapa à degradação ruminal (Faldet \& Satter, 1991; Faldet et al., 1991; Knapp et al., 1991; Stern et al., 1985; Tice et al., 1993), podendo atingir valores de $40 \%$ a $60 \%$ de PNDR como porcentagem da PB. A redução do tamanho de partícula diminui a quantidade de PNDR da soja tostada de $48 \%$, no grão inteiro, para 29\% da PB, no grão moído (Pires et al., 1996). Grummer et al. (1994) determinaram "in vitro" o teor de PNDR da soja tostada como $48 \%$ da $\mathrm{PB}$, mas valores maiores, em torno de $52,3 \%$, foram encontrados "in vivo" por Grummer et al. (1996), concluindo que a determinação "in vitro" pode estar subestimando a quantidade de PNDR "in vivo", pois a soja tostada é moída antes de ser analisada. 


\subsubsection{Efeitos da tostagem da soja grão}

Dhiman et al. (1997) relataram que o processo de tostagem da soja provoca reações de Maillard entre o grupo aldeído do açúcar e grupos amino livres, reduzindo a PDR e destruindo alguns fatores antinutricionais, tais como inibidores de tripsina, os quais não são totalmente inativados no rúmen.

A tostagem parece reduzir a concentração de ácido graxo da soja, provocando mudanças quimicas, afetando o mensuramento do lipídeo, ou devido às perdas de lipídeos durante o processamento (Scott et al., 1991).

Estudos indicaram uma baixa digestibilidade do ácido graxo da soja crua (Scott et al., 1991; Tice et al., 1993) e da soja tostada (Grummer et al., 1996), apesar do processo de tostagem tender a aumentar a digestibilidade dos ácidos graxos e a concentração de ácidos graxos poliinsaturados no leite (Tice et al., 1994).

Reddy et al. (1994) observaram que a tostagem reduziu a liberação de ácidos graxos livres no rúmen, aliviando o efeito inibitório destes sobre a digestão da fibra, reduzindo os grupos carboxil livre (principais responsáveis pela depressão da digestibilidade da fibra). Provavelmente, a alta temperatura provoca mudanças químicas (quebra dos peróxidos de ácidos graxos insaturados, que ligam-se à grupos amino de proteínas), ou reduz a taxa de digestão da MS da soja, tornando mais lenta a liberação do óleo da soja no rúmen.

Vários autores (Faldet et al., 1991; Knapp et al., 1991; Tice et al., 1993) consideraram vantajosa a tostagem da soja grão, pois observaram aumentos na produção de leite sem ocorrer depressão na gordura do leite (Mohamed et al., 1988; Ruegsegger \& Schutz, 1985). Entretanto, a grande diversidade de respostas de produção de leite com o uso de soja tostada se deve provavelmente ao método e à variação do calor aplicado (Dhiman et al., 1997).

A qualidade do processamento é de extrema importância, embora a tostagem aumente a liberação de Lis pós ruminalmente na ordem de 62 a $72 \%$; 
a Lis é um AA muito vulnerável à alta temperatura e o tempo de exposição ao calor afeta negativamente a sua disponibilidade nutricional, podendo ocorrer perdas da ordem de $22 \%$, com a exposição por $3 \mathrm{~h}$ (Faldet et al., 1991).

Os novos métodos e equipamentos de tostagem de soja parecem ser mais eficientes. Dhiman et al. (1997) relataram que a qualidade comercial do processamento de tostagem da soja tem aumentado nos últimos tempos devido à disponibilidade de procedimentos que medem a extensão do tratamento com o calor. Armentano et al. (1997) observaram adequadas concentrações de Lis em dietas com soja tostada, mas limitadas em Met.

\subsubsection{Farelo de glúten de milho}

farelo de glúten de milho apresenta em média $67,2 \%$ de $\mathrm{PB}, 2,06$ $\mathrm{Mcal} / \mathrm{kg}$ de $E L_{\text {Lac }}$ e $2,4 \%$ de EE (NRC, 1988).

A qualidade da proteína do farelo de glúten de milho é considerada inferior à da proteína de soja (Schwab, 1994; Santos et al., 1998). Piepenbrink \& Schingoethe (1998) compararam o perfil de AA da proteina original e da PNDR do farelo de glúten de milho com a proteina do leite, encontrando os mesmos AA limitantes (Lis, Triptofano e Isoleucina) na matéria original e na PNDR, considerando desta forma o farelo de glúten de milho um alimento desbalanceado, o qual não deve ser fornecido como única fonte protéica para vacas em lactação.

A degradação ruminal da PB do farelo de glúten de milho é menor do que da MS, sugerindo que as demais frações químicas são mais degradáveis do que a fração protéica (Piepenbrink \& Schingoethe, 1998), provavelmente devido à remoção de grande parte da proteina solúvel durante 0 processamento do milho para a obtenção do farelo de glúten de milho (Clark et al., 1987); porém, os valores estimados de digestibilidade da PNDR do farelo de glúten de milho no intestino são considerados elevados, da ordem de $94,2 \%$ (Calsamiglia \& Stern, 1995). 
O valor de tabela do NRC (1988) para o teor de PNDR, como porcentagem da $\mathrm{PB}$, do farelo de glúten de milho é $55 \%$. Entretanto, Annexstad et al. (1987) determinaram a PNDR do farelo de glúten de milho "in situ" como $66,4 \%$, valor maior do que o esperado "in vivo". Wohlt et al. (1991), relacionando $\mathrm{N}$ solúvel e PDR, também encontraram valores maiores do que os de tabela, próximos a $70 \%$, mas Higginbotham et al. (1989) encontraram resultados similares aos obtidos "in vivo" publicado pelo NRC (1985).

Robinson et al. (1991) sugeriram que a PNDR é variável de acordo com a kp, em dieta a base silagem de milho. Cozzi \& Polan (1994) determinaram o valor de PNDR "in situ" do farelo de glúten de milho em torno de 93,4\%, assumindo uma $\mathrm{kp}$ de $8 \% / \mathrm{h}$ e $91,9 \%$ para uma $\mathrm{kp}$ mais lenta $(5 \% / \mathrm{h})$. O alto valor de PNDR encontrado por Cozzi \& Polan (1994) é discutível. Stern \& Satter (1982), atribuiram à natureza gelatinosa e à pequena superfície de exposição do farelo de glúten de milho nos saquinhos de "nylon" os altos valores de PNDR. Em outro experimento "in situ" onde o farelo de glúten de milho foi misturado com palha, os valores observados foram de 70 a $75 \%$ de PNDR (Cozzi et al., 1993). 


\subsubsection{Uréia}

A uréia é um composto orgânico rico em NNP, possui $45 \%$ de $N$, com potencial equivalente a $281 \%$ de $\mathrm{PB}$ e, no rúmen, é convertida em $\mathrm{PM}$ através da ação dos microrganismos (NRC, 1988).

\subsection{Efeito de fonte protéica}

\subsubsection{Ingestão de matéria seca}

\subsubsection{Comparação entre farelo de soja e soja tostada}

A ingestão de matéria seca (IMS) não foi influenciada por fonte de proteína na maioria dos experimentos (Mielke \& Schingoethe, 1981; Ruegsegger \& Schultz, 1985; Knapp et al., 1991; Bernard et al., 1992; Tice et al., 1993; McNiven et al., 1994) que compararam farelo de soja e soja tostada, inclusive em dietas com silagem de milho, sugerindo que o óleo da soja tostada não deprimiu a digestão da fibra. Entretanto, outros autores (Baker et al., 1985; Mohamed et al., 1988; Pires et al., 1996) encontraram maior IMS em dieta com farelo de soja do que com soja tostada.

\subsubsection{Comparação entre farelo de soja e farelo de glúten de milho}

Quando os animais foram alimentados com dietas a base de alfafa, a substituição total ou parcial do farelo de soja por farelo de glúten de milho não alterou a IMS (Higginbotham et al., 1989, Taylor et al., 1991; Berzaghi \& Polan, 1991; Robinson et al., 1991).

Dietas contendo silagem de trigo, quando 0 farelo de soja foi comparado com uma mistura de farelo de glúten de milho e proteína de soja rica em PNDR não ocorreu efeito de fonte de proteína em um experimento 
(Nianogo et al., 1991;), mas o tratamento farelo de soja foi superior ao farelo de glúten de milho em outro (Keery et al., 1993).

Nas dietas à base de silagem de milho quando o farelo de soja foi comparado com uma mistura de farelo de glúten de milho e proteína de alfafa (Price et al., 1988) ou uma mistura de farelo de glúten de milho e proteína de soja rica em PNDR (Annexstad et al., 1987) a IMS não foi alterada. Resultados similares foram observados quando o farelo de soja foi substituído totalmente por farelo de glúten de milho (Klusmeyer et al., 1990; Wohlt et al., 1991; Arieli et al., 1996). Apenas Cozzi \& Polan (1994) com substituição parcial do farelo de soja por farelo de glúten de milho observaram menor IMS para o farelo de soja. Entretanto, Polan et al. (1991) verificaram menor IMS para o farelo de glúten de milho quando este substituiu totalmente o farelo de soja, sendo esta depressão aliviada com a inclusão de Lis.

\subsubsection{Comparação entre farelo de soja e uréia}

Baterman et al. (1994) e Baker et al. (1995) não constataram efeito de fonte protéica sobre a IMS quando o farelo de soja foi parcialmente substituido por uréia. Resultados similares foram verificados por outros autores quando o farelo de soja foi totalmente substituído por uréia, em dieta a base de silagem de milho (Broderick (1986); Broderick et al., 1993), ou alfafa (Lines \& Weiss, 1996).

Em experimentos onde o farelo de soja foi substituído parcialmente por uréia e combinado com fontes de carboidratos de diferentes degradabilidades, Casper \& Schingoethe (1986), utilizando dieta exclusiva de silagem de milho, constataram que o tratamento pobre em carboidrato fermentável favoreceu 0 farelo de soja, ocorrendo o inverso com o rico em carboidrato fermentável, onde a substituição parcial de farelo de soja por uréia apresentou maior IMS. Johnson et al. (1987), ao compararem dietas com $25 \%$ silagem de milho, $25 \%$ feno de alfafa e espiga de milho de alta umidade, constataram superioridade do 
farelo de soja sobre uma mistura de grão de cervejaria fresco com $0,72 \%$ de uréia. Entretanto, Casper et al. (1990), utilizando dieta com $40 \%$ de silagem de milho e $10 \%$ de feno de alfafa, observaram maior IMS quando a uréia foi adicionada à dieta com carboidrato de menor degradabilidade ruminal (milho) do que maior (cevada), concluindo que a taxa de degradação da uréia e da cevada devem ser incompativeis, havendo efeito de interação entre fonte de carboidrato e de proteina.

Santos et al. (1998) utilizaram dieta a base de feno de alfafa, em mistura com casca e caroço de algodão e sorgo floculado (360 g/L), combinado com diferentes fontes protéicas (uréia, farelo de soja e farinha de peixe). O tratamento uréia foi mais eficiente em aumentar a IMS do que o farelo de soja, tanto com vacas de produções acima de $40 \mathrm{~kg} / \mathrm{d}$, como abaixo de $40 \mathrm{~kg} / \mathrm{d}$.

\subsubsection{Produção de leite}

\subsubsection{Comparação entre farelo de soja e soja tostada}

Na maioria dos experimentos (Baker et al., 1985; Voss et al., 1988; Bernard et al., 1992; McNiven et al., 1994; Pires et al., 1996) onde a silagem de milho contribuía com grande parte do volumoso, não houve diferença de produção de leite entre farelo de soja e soja tostada. Ocorreu tendência de aumento de produção de leite com o uso de farelo de soja em um experimento (Pires et al., 1996) e maior produção de leite com soja tostada em outro (Baker et al., 1985).

Voss et al. (1988) sugeriram que a soja tostada pode ter maior potencial para aumentar a produção de leite com dietas à base de silagem de alfafa, devido a alta solubilidade da proteina desta forrageira. Faldett \& Satter (1991) e Knapp et al.(1991), ao utilizarem dieta a base de alfafa, observaram

maiores produções de leite e de leite corrigido para gordura com o tratamento 
contendo soja tostada. Knapp et al. (1991) acreditam que o valor de tabela do NRC (1988) da $E L_{\text {Lac }}$ da soja tostada (2,18 Mcal) estaria subestimado em $24 \%$.

\subsubsection{Comparação entre farelo de soja e farelo de glúten de milho}

As respostas de produção de leite em dietas a base de alfafa foram variadas. Robinson et al.(1991) não observaram diferença entre as produções de leite de vacas alimentadas com farelo de soja ou farelo de soja substituido parcialmente por farelo de glúten de milho. Nos experimentos onde o farelo de soja foi substituído totalmente por farelo de glúten de milho, Higginbotham et al. (1989) não observaram efeito sobre as produções de leite e leite corrigido para gordura e Taylor et al. (1991) constataram maior produção de leite com o uso de farelo de soja, mas Berzaghi \& Polan (1991) encontraram maiores produções de leite e leite corrigido para gordura com o uso de farelo de glúten de milho, concluindo que a proteína que escapa do rúmen estimula a produção adicional de leite, quando vacas foram alimentadas com alfafa como única fonte de forragem.

As produções de leite e de leite corrigido para gordura de vacas alimentadas com farelo de glúten de milho foram similares às de animais alimentados com farelo de soja, quando o concentrado da ração continha farelo de glúten de milho em mistura com proteína de soja rica em PNDR (farelo de soja tostado ou soja extrusada) em dietas a base de silagem de trigo (Nianogo et al., 1991; Keery et al., 1993) ou silagem de milho (Annexstad et al., 1987). A produção de leite de vacas recebendo uma mistura de farelo de glúten de milho e proteina de alfafa adicionada em dieta contendo silagem de milho (Price et al., 1988) também não foram alteradas por fonte de proteína. Annexstad et al. (1987) sugeriram que dieta com proteina de alta degradabilidade ruminal podem apresentar produções de leite iguais ou superiores à combinação de farelo de glúten de milho e proteina de soja, podendo a proteína protegida não 
acarretar nenhum benefício sobre animais com altas ingestões de alimento e taxas de passagens, como é o caso de vacas de elevada produção de leite.

Em dietas com silagem de milho, Cozzi \& Polan (1994) substituindo farelo de soja parcialmente por farelo de glúten de milho combinado com fontes de carboidrato altamente fermentável no rúmen, observaram maior produção de leite com o uso de farelo de glúten de milho, apesar do leite corrigido para gordura não ter sido alterado. Entretanto, a fonte de proteina não afetou a produção de leite quando o farelo de soja foi substituido totalmente por farelo de glúten de milho em dois experimentos (Wohlt et al. , 1991; Arieli et al., 1996) e diminuiu as produções de leite e leite corrigido durante o início, o meio e a lactação inteira em um experimento (Polan et al., 1991) onde utilizou-se suplementação de Lis e Met, ocorrendo melhora na produção de leite quando o farelo de glúten de milho foi suplementado com Lis protegida. Os autores concluiram que a menor produção de leite do farelo de glúten de milho pode ser explicada pelo fato de dietas à base de milho serem deficientes em Lis, limitando desta forma a sintese de leite, podendo também ser atribuido à diminuição na IMS quando o de farelo de glúten de milho foi utilizado, pois a magnitude da diferença da produção de leite declina com o avanço do estágio de lactação.

\subsubsection{Comparação entre farelo de soja e uréia}

A produção de leite não foi alterada por fonte de proteína quando o farelo de soja foi substituido parcialmente (Baterman et al., 1994; Baker et al., 1995) ou totalmente por uréia, tanto em dieta a base de silagem de milho (Broderick et al., 1993), como de alfafa (Lines \& Weiss, 1996).

Nos experimentos onde o farelo de soja foi substituido parcialmente por uréia e combinado com fontes de carboidratos de diferentes degradabilidades, Casper \& Schingoethe (1986) em dieta exclusiva de silagem de milho, não observaram diferença de produção de leite e leite corrigido a $4 \%$ de gordura, 
quando a dieta continha maior proporção de carboidrato fermentável, mas encontraram menor produção de leite corrigido a $4 \%$ para o tratamento com uréia, quando a dieta continha menor concentração de carboidrato fermentável, concluindo que vacas alimentadas com dietas contendo uréia podem suportar produções similares às contendo proteína verdadeira (Farelo de soja), caso as dietas sejam favorecidas com fontes de carboidrato rapidamente fermentáveis.

Johnson et al. (1987) ao comparem dietas com $25 \%$ de silagem de milho, $25 \%$ de feno de alfafa e fonte de carboidrato altamente fermentável no rúmen, não encontraram diferença significativa em produção de leite e leite corrigido a $4 \%$ entre farelo de soja e uréia.

Casper et al. (1990), utilizando dieta com $40 \%$ de silagem de milho e $10 \%$ de feno de alfafa e diferentes fontes de CNE fermentável no rúmen (milho $X$ cevada), observaram menor produção de leite corrigido a $4 \%$ de gordura com o uso de uréia e cevada (maior fermentação ruminal) em comparação ao demais tratamentos ( farelo de soja e milho, farelo de soja e cevada e uréia e milho), havendo efeito de interação entre fontes de carboidrato e de proteina. Os autores acreditaram que a sincronização entre as fontes de CNE e de proteína é mais importante do que a degradabilidade ruminal em si, podendo o milho ser mais apropriado para a utilização de NNP do que a cevada. Fontes de $\mathrm{N}$ rapidamente solúveis, como uréia, combinada à adequadas fontes de CNE podem suportar produções similares às fontes de proteína verdadeira.

Santos et al. (1995) utilizando farinha de peixe, farelo de soja "expeller" (rica em PNDR), farelo de soja ou uréia em dieta com sorgo floculado (densidade de $360 \mathrm{~g} / \mathrm{L}$ ), não observaram efeito de fonte protéica sobre a produção de leite. Entretanto, Santos et al. (1998) utilizando diferentes fontes de proteína em dietas a base de feno de alfafa, casca e caroço de algodão e sorgo floculado (360 $\mathrm{g} / \mathrm{L}$ ), verificaram diferentes respostas de produção de leite de acordo com a produção do animal. Vacas no início da lactação com produções de leite acima de $40 \mathrm{~kg} / \mathrm{d}$ (próximas de $46 \mathrm{~kg} / \mathrm{d}$ ) responderam à suplementação de proteína verdadeira (farelo de soja ou farinha de peixe); 
entretanto, vacas com produções inferiores a $40 \mathrm{~kg} / \mathrm{d}$ (próximo a $35 \mathrm{~kg} / \mathrm{d}$ ) apresentaram maiores produções de leite e leite corrigido a $3,5 \%$ de gordura com o uso de uréia do que de proteina verdadeira, sugerindo que vacas alimentadas com alto teor de amido degradável no rúmen respondem menos ao aumento de PNDR devido ao maior estímulo de sintese de PM e o aumento na produção de leite de vacas de alta produção com o uso de proteína verdadeira se deve provavelmente ao aumento na absorção de AAE. O beneficio do tratamento uréia sobre a produção de leite de animais com média de $35 \mathrm{~kg} / \mathrm{d}$, foi provavelmente consequência do aumento na IMS, que promoveu a ingestão de nutrientes e a suplementação adequada de AA.

\subsubsection{Composição do leite}

\subsubsection{Comparação entre farelo de soja e soja tostada}

A porcentagem e produção de gordura do leite não apresentaram uma tendência consistente em relação à fonte protéica. Mohamed et al.(1988), Bernard et al. (1992), McNiven et al. (1994) e Pires et al. (1996) não verificaram efeito de fonte de proteina sobre a composição do leite. Outros experimentos constataram aumento na produção (Knapp et al., 1991) e porcentagem (Faldet \& Satter, 1991; Ruegsegger \& Schultz, 1985; Voss et al., 1988) de gordura no leite com o uso de soja tostada comparado ao farelo de soja. Já Baker et al. (1985) observaram depressão na porcentagem da gordura do leite .

A maioria dos autores (Baker et al., 1985; Mohamed et al., 1988; Voss et al., 1988; Faldet \& Satter, 1991; Knapp et al., 1991; McNiven et al., 1994; Pires et al., 1996) observaram efeito negativo do uso de soja tostada sobre a porcentagem de proteína do leite, com exceção de um experimento (Bernard et al., 1992), onde não houve efeito de fonte de proteína. Knapp et al. (1991)

observaram aumento na produção de proteína do leite com o uso de soja tostada, mas McNiven et al. (1994) não verificaram efeito de fonte protéica. 
Estes dados indicam que a suplementação de lipideo, inclusive através de sementes oleaginosas, geralmente deprimem a porcentagem de proteína do leite.

\subsubsection{Comparação entre farelo de soja e farelo de glúten de milho}

Nos experimentos onde o farelo de glúten de milho foi fornecido exclusivamente com dieta a base de alfafa, as porcentagens de gordura e proteína não foram alteradas pela fonte de proteína na maioria dos experimentos (Higginbotham et al., 1989; Taylor et al. ,1991; Berzaghi \& Polan , 1991; Robinson et al., 1991); somente Berzaghi \& Polan (1991) observaram maiores produções de gordura e de proteína do leite com o uso de farelo de glúten de milho.

Os teores e as produções de gordura e proteína do leite de vacas alimentadas com farelo de glúten de milho em mistura com proteina de alfafa (Price et al., 1988) ou proteína de soja rica em PNDR (Annexstad et al., 1987; Nianogo et al., 1991; Keery et al., 1993) foram similares aos de animais alimentados com farelo de soja em dieta contendo silagem de trigo ou milho, exceto quando a dieta foi suplementada com lipídeo (Keery et al., 1993), onde a porcentagem de gordura do leite foi menor para o farelo de soja do que para o farelo de glúten de milho.

Em dietas com silagem de milho substituindo parcialmente o farelo de soja por farelo de glúten de milho, Cozzi \& Polan (1994), utilizando fonte de CNE altamente degradável no rúmen, não constataram efeito de proteína sobre os teores de gordura e proteína do leite e sobre a produção de gordura, mas observaram aumento na produção de proteína do leite com o uso de farelo de glúten de milho, provavelmente devido às diferenças em produção de leite. A porcentagem e a produção de proteína e de gordura do leite não foram afetados com a substituição total de farelo de soja por farelo de glúten de milho. (Wohlt et al., 1991; Arieli et al. , 1996), apenas Polan et al. (1991) utilizando 
suplementação com Lis e Met, constataram que a porcentagem de gordura do leite foi maior para o farelo de glúten de milho do que farelo de soja, apesar da produção de gordura do leite não ter sido alterada; contudo, a porcentagem e produção de proteina do leite foram menores para o farelo de glúten de milho do que farelo de soja e a suplementação com Lis aliviou a queda na produção e no conteúdo de proteína do leite das vacas alimentadas com farelo de glúten de milho.

\subsubsection{Comparação entre farelo de soja e uréia}

A composição do leite não foi alterada por fonte de proteína quando o farelo de soja foi parcialmente (Baterman et al., 1994; Baker et al., 1995) ou totalmente substituído por uréia, em dieta a base de silagem de milho (Broderick et al., 1993) e de alfafa (Lines \& Weiss,1996).

Nos experimentos onde o farelo de soja foi substituido parcialmente por uréia e combinado com fontes de carboidratos de diferentes degradabilidades, Casper \& Schingoethe (1986) em dieta com silagem de milho, não encontraram efeito sobre a composição do leite, com exceção do tratamento farelo de soja combinado com menor concentração de carboidrato fermentável, que aumentou a porcentagem de gordura no leite.

Johnson et al. (1987) ao compararem dietas com $25 \%$ silagem de milho, $25 \%$ feno de alfafa e CNE altamente fermentável no rúmen, não encontraram diferença significativa na composição do leite entre farelo de soja e uréia.

Casper et al. (1990), utilizando dieta com $40 \%$ de silagem de milho e $10 \%$ de feno de alfafa, não observaram efeito da fonte protéica sobre a porcentagem de gordura e proteína do leite, mas constataram efeito de interação entre fonte de CNE (milho e cevada) e proteína (uréia e farelo de soja) sobre a porcentagem de proteína do leite, verificando maior porcentagem de proteína no leite para o tratamento uréia combinado com milho em 
comparação aos demais tratamentos (milho e farelo de soja, cevada e uréia e cevada e farelo de soja).

Santos et al. (1998), utilizando dieta a base de sorgo floculado (360 $\mathrm{g} / \mathrm{L}$ ), rico em amido degradável no rúmen, e feno de alfafa com caroço de algodão, não observaram diferença sobre a composição do leite, quando o farelo de soja foi totalmente substituído por uréia.

\subsubsection{Digestibilidade}

\subsubsection{Comparação entre farelo de soja e soja tostada}

A dieta com soja tostada não afetou a digestibilidade aparente da MS (Mohamed et al., 1988; Bernard et al., 1992) e da PB (Bernard et al., 1992; Knapp et al., 1991), como também a digestibilidade "in situ" da MS e do FDN (Knapp et al., 1991), mas aumentou a digestibilidade aparente do FDA e do FDN (Bernard et al., 1992) comparado ao tratamento farelo de soja. Entretanto, a menor digestibilidade do FDA e FDN da dieta contendo farelo de soja foi provavelmente devido ao maior teor de FDA desta dieta e às maiores quantidades de amido deste tratamento, que alterou 0 ambiente ruminal $e$ consequentemente a degradação da fibra.

\subsubsection{Comparação entre farelo de soja e farelo de glúten de milho}

Nianogo et al. (1991) e Keery et al. (1993) ao compararem o farelo de soja com uma mistura de farelo de glúten de milho e proteina de soja rica em PNDR (farelo de soja tostada), em dieta contendo silagem de trigo, não constataram efeito de fonte protéica sobre a digestibilidade da MS, do FDN, do FDA, da hemicelulose e da celulose, com exceção da digestibilidade da PB que foi maior para o farelo de soja. Entretanto, quando a dieta foi suplementada com lipídeo, nenhum nutriente teve sua digestibilidade alterada pela fonte 
protéica, observando uma interação entre ingestão de lipídeo e digestibilidade de proteina (Keery et al., 1993).

Em dieta contendo silagem de milho não observou-se efeito de fonte de proteína, quando o farelo de soja foi comparado com um concentrado composto por uma mistura de farelo de glúten de milho e proteína de alfafa (Price et al., 1988), sobre a digestibilidade aparente da MS no rúmen, no ID e no trato total e quando comparado com uma substituição parcial (Cozzi \& Polan, 1994) ou total por farelo de glúten de milho (Wohlt et al., 1991; Arieli et al., 1996), sobre a digestibilidade da MS e da PB. Klusmeyer et al. (1990) avaliaram o efeito da substituição total do farelo de soja por farelo de glúten de milho em diferentes teores de $\mathrm{PB}$, não verificando efeito de fonte protéica sobre a digestibilidade aparente ruminal, pós ruminal e no trato total da $\mathrm{MO}$, do amido, do FDA e do FDN, apenas o teor de PB alterou a digestibilidade da PB, apresentando maior digestibilidade da PB a dieta com $14,5 \%$ do que a dieta com $11 \%$ de PB.

\subsubsection{Comparação entre farelo de soja e uréia}

Lines \& Weiss (1996) compararam dietas contendo feno de alfafa com substituição total do farelo de soja por uréia, observando que a digestibilidade da MS e da MO foram afetadas negativamente pelo tratamento uréia. Entretanto, Santos et al. (1998) em dieta com feno de alfafa e sorgo floculado, não observaram efeito da substituição do farelo de soja por uréia sobre a digestibilidade da MS, MO, amido, FDN e FDA, mas verificaram aumento na digestibilidade da PB com o uso de uréia. 


\subsubsection{Parâmetros Ruminais}

\subsubsection{Comparação entre farelo de soja e soja tostada}

O pH ruminal, as porcentagens molares de AGV, as relação acetato:propionato e a concentração de amônia ruminal não foram alterados pela fonte de proteína (Mohamed et al., 1988; Knapp et al., 1991), indicando que a adição de soja tostada não afetou a fermentação ruminal, suportando a teoria de que o encapsulamento do óleo de soja dentro da semente de soja e a gradual liberação deste, previne o efeito negativo sobre a fermentação ruminal associada com as formas de óleos poliinsaturados livres.

\subsubsection{Comparação entre farelo de soja e farelo de glúten de milho}

Os parâmetros ruminais (concentração de amônia, pH, concentrações molares dos AGV e relação acetato:propionato) de animais que receberam dieta contendo alfafa não foram alterados pela fonte protéica e teor de PB (Higginbotham et al., 1989; Robinson et al., 1991), ficando a exceção por conta da concentração de amônia ruminal, que aumentou com a maior porcentagem de PB na dieta.

Em dietas com silagem de milho e diferentes teores de PB, apesar da maioria dos parâmetros ruminais $(\mathrm{pH}$ e porcentagens molares de acetato, propionato e butirato) não terem sido afetados pela fonte protéica, a concentração de AGV total e de amônia ruminal foram maiores para 0 tratamento farelo de soja. $O$ teor de $P B$ na dieta alterou significativamente os parâmetros ruminais e a menor porcentagem de $\mathrm{PB}$ da dieta aumentou o $\mathrm{pH}$, a porcentagem molar do acetato e a taxa acetato:propionato, mas diminuiu as concentrações de amônia, de AGV total e a porcentagem molar do propionato (Klusmeyer et al., 1990). 
Price et al. (1988) compararam o farelo de soja com uma mistura de farelo de glúten de milho e proteina de alfafa, em dietas com silagem de milho. A fonte de proteina não alterou o $\mathrm{pH}$ do rúmen, mas o tratamento farelo de soja aumentou as concentrações de amônia, AGV total e butirato e a relação acetato:propionato, indicando maior extensão de fermentação ruminal da dieta com farelo de soja do que farelo de glúten de milho. Entretanto, Annexstad et al. (1987) ao compararem farelo de soja com farelo de glúten de milho em mistura com proteina de soja rica em PNDR, observaram efeito do farelo de soja apenas sobre a concentração de amônia ruminal.

Em dietas a base de silagem de milho, onde as fontes protéicas de diferentes teores de PDR (farelo de soja $x$ farelo de glúten de milho) foram combinadas com diferentes teores de matéria orgânica degradável no rúmen (MODR), Arieli et al. (1996) observaram que os parâmetros ruminais (porcentagens molares de AGV, o pH e a concentração de amônia) foram mais relacionadas ao teor de MODR do que PDR. A alta quantidade de MODR comparada à baixa MODR, aumentou a concentração de AGV total em $24 \%$ e a porcentagem molar de propionato em $17 \%$, mas diminuiu a porcentagem molar de acetato em $8 \%$ e o pH ruminal em 0,5 unidades.

\subsubsection{Comparação entre farelo de soja e uréia}

Nos experimentos onde o farelo de soja foi substituído parcialmente por uréia e combinado com fontes de carboidratos de diferentes degradabilidades, tanto em dieta contendo silagem de milho como única fonte de volumoso (Casper \& Schingoethe, 1986) como em mistura com feno de alfafa (Casper et al., 1990), a fonte de proteína não alterou o pH e as concentrações dos AGV no rúmen; somente a concentração de amônia ruminal foi significativamente maior para o tratamento uréia. Casper \& Schingoethe (1986) constataram aumento na proporção molar de propionato e redução na de acetato com o tratamento uréia, indicando alteração na fermentação ruminal, podendo ser devido a 
substituição de parte do farelo de soja por milho no tratamento uréia, acarretando em maior suplementação de amido e proliferação de microrganismos produtores de propionato.

A substituição total do farelo de soja por uréia não alterou o pH do rúmen, mas aumentou a concentração de amônia ruminal (Lines \& Weiss, 1996; Broderick, 1986). Contudo, os resultados de AGV não foram similares, Lines \& Weiss (1996) não observaram efeito sobre a concentração de AGV, mas Broderick (1986) encontrou maior porcentagem molar de acetato, menores porcentagens molares de propionato e butirato e menores concentrações de AGV totais e ramificados para o tratamento uréia, concluindo que a alteração nas porcentagens molares do acetato, propionato e butirato pode estar associada ao aumento numérico de IMS. A baixa concentração dos AGV de cadeia ramificada implica em um baixo conteúdo de proteina pré formada no tratamento uréia. Os $A G V$ de cadeia ramificada são provenientes da deaminação e descarboxilação de $A A$ de cadeia ramificada, estando associados à degradação da proteina ruminal.

\subsubsection{Parâmetros Sanguíneos}

O excesso de amônia proveniente de suplementação com uréia ou PDR pode afetar o metabolismo de glucose (NRC, 1988). O aumento da quantidade de PB de 10,7\% para 22,1\% com a adição de uréia (Leonard et al., 1977, citado pelo NRC, 1988) ou a substituição de proteína de soja por uréia (Prior et al., 1972, citado pelo NRC, 1988) diminuíram a concentração plasmática da glucose. A utilização de doses subtóxicas de uréia diminuíram a taxa de utilização da glucose (Spires \& Clark, 1979, citado pelo NRC, 1988), observando-se uma redução na formação de glucose (proveniente de propionato) no fígado de ovino comprometido com a detoxificação da amônia (Weekes et al., 1979, citado pelo NRC, 1988). 


\subsubsection{Comparação entre farelo de soja e soja tostada}

Em dietas com PB próxima a $17 \%$, a inclusão de soja tostada na dieta não alterou a concentração de glucose (Pires et al., 1996; Mohamed et al., 1988) e insulina plasmática (Mohamed et al., 1988).

\subsubsection{Comparação entre farelo de soja e farelo de glúten de milho}

A concentração de uréia plasmática foi avaliada em animais recebendo dieta cujo o volumoso era alfafa, onde o farelo de soja foi comparado ao farelo de glúten de milho em substituição parcial (Robinson et al., 1991) ou total com diferentes teores de PB (Higginbotham et al., 1989). A concentração de uréia plasmática foi alterada por teor e fonte de proteina, aumentando com a maior porcentagem de PB na dieta e com o tratamento farelo de soja, devido ao aumento de concentração de amônia ruminal, mas a concentração de glucose plasmática não foi influenciada por fonte e teor de proteína da dieta.

Em dietas contendo silagem de milho a substituição parcial ou total de farelo de soja por farelo de glúten de milho não alterou a concentração de uréia plasmática (Wohlt et al., 1991 e Cozzi \& Polan, 1994). Arieli et al. (1996) identificaram efeito de interação entre fonte de proteína e MODR, onde a dieta com alta PDR (farelo de soja) e baixa MODR apresentou uma concentração de uréia plasmática $27 \%$ maior do que os demais tratamentos. 


\subsubsection{Comparação entre farelo de soja e uréia}

Casper \& Schingoethe (1986) e Casper et al. (1990) observaram o efeito da substituição parcial de farelo de soja por uréia combinado com fontes de carboidratos de diferentes degradabilidades (milhoXsoro e milhoXcevada), em dieta com silagem de milho como único volumoso ou em mistura com feno de alfafa. A concentração de uréia plasmática não foi alterada pela fonte de proteína, mesmo quando a concentração de amônia no rúmen aumentou com o uso de uréia. Baker et al. (1995), em dieta contendo silagem de milho e alfafa, compararam farelo de soja, farelo de glúten de milho e uréia. A concentração da uréia plasmática do tratamento uréia não diferiu do farelo de soja, mas foi superior ao farelo de glúten de milho.

Em ensaios onde o farelo de soja foi totalmente substituido por uréia, Broderick (1986) não observou efeito de fonte protéica sobre a concentração de uréia plasmática. Entretanto, Broderick et al. (1993) e Lines \& Weiss (1996) verificaram aumento na concentração de uréia plasmática com o uso de uréia.

A concentração de glucose plasmática não foi afetada por fonte de proteina quando o farelo de soja foi substituído totalmente por uréia (Broderick et al., 1993).

\subsection{Justificativas para a hipótese de trabalho}

De acordo com a revisão de literatura apresentada, na maioria dos estudos sobre fontes protéicas, a suplementação com PNDR não aumentou o fluxo de proteina e de AAE para o intestino, nem a produção de leite. Ultimamente, tem-se enfatizado a importância da qualidade da fonte protéica, a qual está relacionada ao balanço de $A A E$, e principalmente ao teor de Lis e Met ( $A A$ mais limitantes à produção de leite e sintese de proteina do leite). De acordo com estes novos conceitos, em termos de AAE, a PM é considerada de excelente qualidade, sendo superior às fontes comerciais ricas em PNDR, e o 
uso de PNDR deve ocorrer após a máxima exploração da sintese microbiana no rúmen, para complementar a PM em termos de AAE.

Portanto, se faz necessário a realização de pesquisas de metabolismo com vacas de leite de alta produção, a fim de se identificar combinações de fontes protéicas e energéticas, que sincronizem a disponibilidade ruminal de energia e de $\mathrm{N}$ para otimizar a síntese de PM e o fluxo de nutrientes para o ID, sendo importante a avaliação do ambiente ruminal $(\mathrm{pH}$, produção de AGV e concentração de amônia), do perfil de AAE que chega no ID, assim como dos parâmetros sanguíneos do animal, simultaneamente aos índices de IMS e produção de leite. Portanto, o intuito deste trabalho foi avaliar o efeito da adição de fontes protéicas com diferentes degradabilidades ruminais e com diferentes perfis de $A A E$ em dietas ricas em amido degradável no rúmen (milho grão floculado), com silagem de milho como único volumoso. 


\section{MATERIAL E MÉTODOS}

\subsection{Animais e instalações experimentais}

Foram utilizadas cinco (5) vacas holandesas preto e branco, multiparas, com produção de leite próxima a $30 \mathrm{~kg} / \mathrm{d}$ e peso médio em torno de $550 \mathrm{~kg}$. Os animais foram fistulados aproximadamente aos 45 dias pós parto, utilizando-se cânulas de 4" no rúmen e do tipo $T$ no duodeno (a $10 \mathrm{~cm}$ do piloro). O período experimental iniciou-se um mês após a intervenção cirúrgica.

O experimento foi conduzido nas instalações do Centro de Pesquisa de Nutrição Animal (CEPENA) do setor de Ruminantes do Departamento de Produção Animal da Escola Superior de Agricultura "Luiz de Queiroz" - USP. Os animais foram alojados em um galpão coberto equipado com ventiladores e mantidos em baias individuais do tipo "tie stall" $(2,5 \times 1,1 \mathrm{~m})$. As baias eram equipadas com comedouros individuais e um bebedouro automático a cada 2 baias; no piso foi colocado um tapete de borracha, mantendo-o com uma camada de maravalhas de madeira.

\subsection{Tratamentos}

As dietas foram isoenergéticas, a base de silagem de milho, milho floculado (360 g/L) e caroço de algodão, variando-se o teor e a fonte de proteina. O tratamento controle foi formulado para conter $13,50 \%$ de $\mathrm{PB}$ na dieta e os demais tratamentos em torno de $16,5 \%$ de $\mathrm{PB}$, sendo esta diferença de PB complementada por diferentes fontes de proteína, conforme apresentado 
na Tabela 1, constituindo cinco tratamentos distintos: 1. Controle (C), 2. Uréia (U), 3. Farelo de Soja (FS), e 4. Soja Tostada (ST), 5. Farelo de Glúten de Milho (FGM). O caroço de algodão foi utilizado para equilibrar o teor de lipídeo dos tratamentos em relação ao tratamento ST. Os tratamentos $C$, FS e U caracterizavam-se por conterem fontes de proteina ricas em PDR, enquanto os tratamentos FGM e ST continham fontes ricas em PNDR.

Para cada subperiodo o concentrado foi previamente misturado em misturador vertical (marca Lucato, capacidade $500 \mathrm{~kg}$ ), adicionando-o à polpa cítrica e silagem de milho no momento do fornecimento da alimentação, tomando-se o cuidado de manter a proporção de aproximadamente $62 \%$ de concentrado e $38 \%$ de volumoso na MS.

A dieta foi oferecida à vontade, sendo permitido uma sobra de 5 a $10 \%$, evitando-se problemas de limitação de consumo por parte dos animais. A alimentação foi fornecida duas vezes ao dia, com intervalo de 12 horas, as 6:00 e 18:00h, simultaneamente ao horário de ordenha das vacas.

Tabela 1. Composição dos tratamentos como porcentagem da MS.

\begin{tabular}{|c|c|c|c|c|c|}
\hline \multirow[b]{2}{*}{ Ingredientes } & \multicolumn{5}{|c|}{ Dietas } \\
\hline & C & $\mathrm{U}$ & FS & ST & FGM \\
\hline Silagem & 38,2 & 38,17 & 37,5 & 37,74 & 38,18 \\
\hline Milho Floculado $360 \mathrm{~g} / \mathrm{L}$ & 25,73 & 24,68 & 18,32 & 24,27 & 21,03 \\
\hline Polpa de citrus peletizada & 10,65 & 10,66 & 10,83 & 10,78 & 10,66 \\
\hline Núcleo com bicarbonato* & 3,26 & 3,25 & 3,29 & 3,28 & 3,25 \\
\hline Caroço de Algodão & 10,91 & 10,89 & 11,02 & & 10,89 \\
\hline Farelo de Soja & 11,25 & 11,24 & 19,04 & 12,90 & 10,04 \\
\hline Soja tostada & & & & 11,03 & \\
\hline Uréia & & 1,11 & & & \\
\hline Farelo de glúten de milho & & & & & 5,96 \\
\hline
\end{tabular}

* O Núcleo continha $23 \%$ de bicarbonato de sódio. 


\subsection{Periodo experimental}

O experimento foi conduzido durante o verão. O periodo experimental foi composto por cinco subperiodos de 14 dias cada, sendo 10 dias de periodo de adaptação e 4 dias de período de coleta. Durante o periodo de adaptação as vacas foram soltas diariamente para exercicio em um piquete próximo ao galpão por 1 hora/d e durante o período de coleta permaneciam 24 horas/d em baias individuais.

\subsubsection{Administração de óxido de cromo (marcador externo)}

O óxido de cromo foi utilizado como marcador externo. Envelopes de papel contendo $15 \mathrm{~g}$ de óxido de cromo foram introduzidos no rúmen às $8: 00 \mathrm{~h}$ e as 20:00h, perfazendo um total de $30 \mathrm{~g}$ por dia, durante 10 dias consecutivos, após os 4 primeiros dias de cada período experimental.

\subsubsection{Pesagem e amostragem do alimento oferecido e resíduo alimentar}

A composição química da dieta foi calculada com base na composição quimica dos ingredientes de cada tratamento. Os componentes do concentrado foram amostrados separadamente e compostos por vaca dentro de cada subperiodo. A silagem de milho e a polpa de citrus peletizada foram amostradas durante o periodo de coleta, formando uma amostra composta para cada subperíodo. O alimento recusado foi composto por vaca e subperiodo. As amostras de alimento e recusado foram congeladas a $-10^{\circ} \mathrm{C}$ para posterior análise químico-bromatológica.

Durante o período de coleta de cada subperíodo, realizou-se registros

diários de alimento oferecido e sobra e sub-amostras destes foram secas a $105^{\circ} \mathrm{C}$ para o cálculo da ingestão de MS dos animais. 


\subsubsection{Pesagem e amostragem de leite}

As vacas foram ordenhadas duas vezes ao dia as 6:00 h e 18:00 h, realizando-se o controle leiteiro durante o período de coleta de cada subperíodo. Durante os quatro dias de coleta, o leite foi amostrado por ordenha e composto por dia para cada vaca dentro do subperiodo, preservado em 2bromo-2-nitropropano-1-3-diol e armazenado a $6^{\circ} \mathrm{C}$, para posterior análises de proteína e gordura utilizando um analisador por infra vermelho do Laboratório de Análises de Leite do Departamento de Produção Animal da ESALQ-USP.

\subsubsection{Coleta de bolo alimentar do duodeno}

Durante todo o período de coleta (4 dias), amostras do bolo alimentar do duodeno, equivalente a $200 \mathrm{ml}$, foram coletadas com intervalos de 4 horas, adiantando-se uma hora por dia, de modo que cada hora do dia fosse amostrada, perfazendo um total de aproximadamente 5 litros. As amostras foram agrupadas por vaca e período e armazenadas a $-10^{\circ} \mathrm{C}$ para posterior análise químico-bromatológica.

Para a determinação da composição bacteriana, uma segunda amostragem do bolo alimentar do duodeno, equivalente a $500 \mathrm{ml}$, foi realizada a cada 4 horas durante 24 horas, perfazendo um total de 3 litros. O material coletado foi batido em liquidificador por 20 segundos, coado em 4 panos de fralda, armazenado em refrigerador, no máximo por 24 horas, centrifugado a baixa rotação ( $2.000 \times \mathrm{g}$ por 15 minutos) recuperando o sobrenadante, o qual posteriormente foi centrifugado em alta rotação ( $18.000 \times \mathrm{g}$ por 15 minutos). $\mathrm{O}$ "pelote" formado, rico em bactérias, foi congelado a $-10^{\circ} \mathrm{C}$. 


\subsubsection{Coleta de fezes}

Amostras de aproximadamente $100 \mathrm{~g}$ de fezes foram obtidas do reto dos animais, com intervalos de 8 horas, durante os 4 dias de período de coleta, adiantando-se 1 hora por dia. As amostras de fezes foram agrupadas por vaca e período e armazenadas a $-10^{\circ} \mathrm{C}$.

\subsubsection{Coleta de fluido ruminal}

Em cada subperíodo, no último dia de coleta, o fluido ruminal foi coletado com intervalos de 2 horas durante 24 horas. A amostragem foi realizada em 4 pontos diferentes e o conteúdo ruminal coado em 4 panos de fralda, resultando em $300 \mathrm{ml}$ de líquido ruminal. $\mathrm{O} \mathrm{pH}$ foi imediatamente determinado utilizando-se de um potenciômetro digital da Digimed (modelo TE902). Duas sub-amostras de $25 \mathrm{ml}$ do fluido ruminal foram congeladas à $-10^{\circ} \mathrm{C}$ sem o uso de preservativo (Nocek et al., 1987), para posterior análise de amônia e AGV.

\subsubsection{Coleta de sangue}

No primeiro dia de coleta de cada subperíodo, coletou-se amostras de sangue da veia coccígea, com intervalos de 3 horas. O sangue foi colocado em tubos de ensaio a vácuo, contendo fluoreto de sódio e oxalato de potássio como antiglicolítico e anticoagulante. As amostras de sangue foram centrifugadas a $3.000 \times \mathrm{g}$ por 15 minutos, o plasma acondicionado em "ependorf" e congelado $\mathrm{a}-10^{\circ} \mathrm{C}$. 


\subsection{Preparo das amostras e análises laboratoriais}

\subsubsection{Análise da concentração de cromo}

As concentrações de cromo nas amostras do bolo alimentar do duodeno e fezes foram determinadas de acordo com o método de Fenton \& Fenton (1979) e analisadas em espectrofotômetro de absorção atômica.

Entretanto, houve baixa recuperação de marcador $e$ os valores de concentração de cromo encontrados não possibilitaram a avaliação da digestibilidade no rúmen, pós rúmen e trato digestivo total, impossibilitando o cálculo de fluxo de nutrientes para o duodeno.

Em vista dos problemas ocorridos com a recuperação do cromo, a lignina foi usada como marcador interno, possibilitando a determinação das digestibilidades no trato digestivo total, mas novamente a digestibilidade no rúmen e pós rúmen não puderam ser calculadas, devido aos teores incoerentes de lignina encontrados no bolo alimentar do duodeno.

A digestibilidade aparente (D) no trato total da MS e demais nutrientes da dieta foram calculados utilizando-se os valores de lignina, de acordo com a seguinte fórmula:

$D(\%)=100-(100 \times \%$ lignina no alimento $\times \%$ do nutriente nas fezes $)$

$\%$ lignina nas fezes $\%$ do nutriente no alimento

\subsubsection{Análises químico-bromatológicas}

As amostras dos alimento, do recusado, do bolo alimentar do duodeno e das fezes foram secas a $55^{\circ} \mathrm{C}$ durante $72 \mathrm{~h}$, moídas em moinho (marca Willey) com peneira de $1 \mathrm{~mm}$ e analisadas para MS, MO, PB de acordo com o AOAC (1990), amido pelo método descrito por Poore et al. (1991), Fibra em Detergente Neutro (FDN), Fibra em Detergente Ácido (FDA) e lignina de acordo com método de Robertson e Van Soest (1981). As amostras de alimento 
também foram analisadas quanto ao teor de $E E$, de acordo com a $A O A C$ (1990).

Com o intuito de avaliar a variação na composição de AA pós rúmen, sub-amostras de alimento e do bolo alimentar do duodeno foram analisadas no aparelho exclusivo para análise de AA, L-8500A, marca HITACHI, de acordo com a metodologia oficial da AOAC (1994), pelo laboratório particular LABTEC de Campinas/SP.

\subsubsection{Análise de glucose e uréia plasmática}

A glucose plasmática foi lida diretamente em um autoanalisador YSI 2.700 Select (Biochemistry analyser). A uréia plasmática foi analisada de acordo com Chaney \& Marbach (1962), adaptando o método para leitura em aparelho Elisa Reader BIO RAD (absorbância de 550 nanômetros), com resultado em $\mathrm{mg} / \mathrm{dl}$.

\subsubsection{Análise de amônia e AGV no fluido ruminal}

As amostras de fluido ruminal foram descongeladas e centrifugadas a $11.000 \mathrm{~g} \mathrm{a} 4^{\circ} \mathrm{C}$, durante 20 minutos, sendo retirado $4 \mathrm{ml}$ do sobrenadante para posterior análise da concentração de amônia, de acordo com Chaney \& Marbach (1962) adaptado para leitura em aparelho Elisa Reader BIO RAD (absorvância de 550 nanômetros). Outra aliquota de $4 \mathrm{ml}$ foi obtida do sobrenadante para posterior análise de AGV, de acordo com Palmquist \& Conrad (1971), utilizando tubos de HP 5890, em leitura de cromatógrafo líquido gasoso (CLG) equipado com HP Integrador (Hewlett - Packard Company, Avondale, PA). 


\subsection{Análise estatística}

O delineamento experimental foi um Quadrado Latino $5 \times 5$ (cinco animais e cinco periodos experimentais).

Os resultados foram avaliados segundo o PROC GLM (generalized linear models) do programa estatístico SAS (1991). O resumo do quadro de análise de variância está apresentado na Tabela 2.

Tabela 2. Análise de variância para ingestão de MS, eficiência alimentar, produção e composição do leite, digestibilidade dos nutrientes e parâmetros ruminais e sanguineos.

\begin{tabular}{lc}
\hline Causas de Variação & Graus de Liberdade \\
\hline Animal & 4 \\
Periodo & 4 \\
Fonte de proteina & 4 \\
Residuo & 12 \\
TOTAL & 24 \\
\hline
\end{tabular}

A análise da variância da ingestão de MS, da eficiência alimentar, da produção e composição do leite, dos parâmetros ruminais e sanguineos foi realizada comparando-se as médias dos tratamentos pelo teste de Tukey a $5 \%$ de probabilidade sendo que, para os parâmetros ruminais e sanguineos, a análise da variância foi realizada para cada tempo de coleta.

Os parâmetros ruminais $(\mathrm{pH}$, concentração de amônia, concentração molar dos AGV total, porcentagens molares de acetato, de propionato, de butirato, de isobutirato, de isovalerato, de valerato e de total de AGV ramificados e relação acetato:propionato) foram analisados dentro dos tempos de coleta $0,2,4,6,8,10,12,14,16,18,20$ e 22 e os parâmetros sanguíneos (uréia e glucose plasmática), dentro dos tempos de coleta 0, 3 e 6 . 


\section{RESULTADOS E DISCUSSÃO}

\subsection{Composição químico-bromatológica das dietas experimentais}

Os valores de composição quimico-bromatológica encontram-se na Tabela 3 e estão de acordo com os valores de tabela do NRC (1988).

Tabela 3. Composição químico-bromatológica das dietas com base na MS.

\begin{tabular}{lrrrrr}
\hline & \multicolumn{5}{c}{ Dietas } \\
\cline { 2 - 6 } Composição Química & \multicolumn{1}{c}{$\mathrm{C}$} & \multicolumn{1}{c}{$\mathrm{U}$} & \multicolumn{1}{c}{ FS } & \multicolumn{1}{c}{ ST } & FGM \\
\hline MS (\%) & 52,03 & 52,08 & 51,72 & 51,74 & 52,09 \\
MM (\%) & 7,31 & 7,29 & 7,72 & 7,54 & 7,25 \\
MO (\%) & 92,69 & 92,71 & 92,28 & 92,46 & 92,75 \\
PB (\%) & 13,40 & 16,35 & 16,64 & 16,36 & 16,35 \\
PNDR* (\% da PB) & 39,56 & 32,03 & 37,37 & 42,85 & 42,75 \\
Amido (\%) & 32,47 & 31,68 & 26,43 & 31.21 & 30,18 \\
EE (\%) & 4,21 & 4,16 & 4,04 & 4,43 & 4,06 \\
FDN (\%) & 28,86 & 28,74 & 29,74 & 25,46 & 28,34 \\
FDA (\%) & 19,84 & 19,80 & 20,71 & 17,34 & 19,82 \\
Lignina (\%) $_{\text {EL }}^{*}$ (Mcal/kg de MS) & 3,08 & 3,07 & 3,11 & 2,22 & 3,06 \\
\hline
\end{tabular}

* Calculados de acordo com resultados de tabela do NRC (1988), exceto a PNDR da ST, que foi baseada nos valores de Grummer et al. (1996). MM - matéria mineral.

Os teores de $\mathrm{PB}$ e $\mathrm{EL}_{\mathrm{Lac}}$ das dietas foram próximos ao planejado. Os tratamentos $U, S T, F S$ e FGM apresentaram-se isoprotéicos e isoenergéticos, enquanto o tratamento $\mathrm{C}$ com menor teor PB. 
O principal objetivo do experimento foi a comparação de fontes protéicas com diferentes proporções de PDR e PNDR, entretanto, apesar do tratamentos C e FS apresentarem apenas farelo de soja (baixo em PNDR) como fonte protéica, os valores estimados de PNDR destes tratamentos foram acima dos esperados, provavelmente devido o milho floculado apresentar alto valor de PNDR (68\%).

Os valores mínimos de FDA e FDN recomendados pelo NRC (1988), em dietas de vacas de leite, são respectivamente $19 \%$ e $25 \%$. Os tratamentos encontram-se dentro do limite, com exceção do tratamento ST que apresentou FDA abaixo do ideal.

\subsection{Digestibilidade dos nutrientes no trato total}

Os valores de digestibilidade dos nutrientes no trato total estão apresentados na Tabela 4.

Tabela 4. Efeito das fontes protéicas sobre a digestibilidade da MS, MO, PB, amido e FDN ( $\%$ na MS).

\begin{tabular}{lllllll}
\hline & \multicolumn{6}{c}{ Fontes de proteina } \\
\cline { 2 - 6 } Digestibilidade (\%) & $\mathrm{C}$ & \multicolumn{1}{c}{$\mathrm{U}$} & \multicolumn{1}{c}{ FS } & ST & FGM & CV \% \\
\hline IMS (kg/d) & 19,31 & 19,57 & 17,99 & 18,46 & 19,21 & 8,19 \\
MS & 57,88 & 60,62 & 63,40 & 58,12 & 60,04 & 6,67 \\
MO & 59,79 & 62,24 & 65,48 & 59,83 & 61,67 & 5,97 \\
PB & 50,40 b & 59,81 a & 58,13 a & $51,01 \mathbf{b}$ & 60,31 a & 5,77 \\
Amido & 91,17 & 91,69 & 91,43 & 90,97 & 91,30 & 1,15 \\
FDN & 36,84 & 32,18 & 35,26 & 33,19 & 32,74 & 11,46 \\
\hline
\end{tabular}

Médias na mesma linha seguidas de letra diferem entre si $P<0,05$. 


\subsubsection{Digestibilidade da MS}

A fonte de proteina não afetou $(P>0,05)$ a digestibilidade da $M S$ das dietas. Tendo-se observado a mesma tendência na maioria dos trabalhos de literatura que compararam farelo de soja com soja tostada (Mohamed et al., 1988; Bernard et al., 1992), com farelo de glúten de milho (Nianogo et al., 1991; Keery et al., 1993; Price et al., 1988; Wohlt et al., 1991; Cozzi \& Polan, 1994; Arieli et al., 1996; Klusmeyer et al., 1990) e com uréia (Santos et al., 1998).

O teor de $\mathrm{PB}$ da dieta também não alterou $(P>0,05)$ a digestibilidade da MS, porém o tratamento $C$, com $13,4 \%$ de $P B$, apresentou digestibilidade da MS numericamente inferior aos demais tratamentos com média de $16,5 \%$ de PB na dieta.

Os valores de digestibilidade da MS verificados neste estudo encontram-se ligeiramente abaixo dos normalmente relatados na literatura. Isto se deve provavelmente à baixa digestibilidade do FDN observada e ao efeito negativo da suplementação de lipídeo (Keery et al., 1993) e da canulação dos animais sobre as funções digestivas (Theurer, 1986). Em relação ao tratamento ST também pode ser devido ao processo de tostagem (Reddy et al., 1994).

Nos experimentos onde o FS foi utilizado como fonte de proteína em dieta a base de silagem de milho, os valores de digestibilidade da MS no trato total situaram-se em torno de $67,6 \%$ (Cozzi \& Polan,1994) e 70,6\% (Wohlt et al., 1991) e com o uso de silagem de trigo ao redor de 70,3\% (Nianogo et al., 1991). Price et al. (1988) reportaram valor menor, próximo a $61,6 \%$ e Keery et al. (1993), utilizando silagem de trigo, com ou sem suplementação de lipídeo, encontraram valores de $61 \%$ sem lipideo e $57,6 \%$ com lipídeo.

Os valores de digestibilidade da MS do tratamento contendo ST foi numericamente inferior aos demais tratamentos com o mesmo teor de PB. Dhiman et al. (1997) relataram valores de digestibilidade em torno de 63,6\%, enquanto Scott et al. (1991), relataram valores em torno de $57,2 \%$. 
Os estudos contendo farelo de glúten de milho obtiveram digestibilidade da MS próxima a $60,9 \%$ (Price et al., 1988) quando alfafa foi utilizada como volumoso e de 66,7\% (Wohlt et al., 1991) a 68,4\% (Cozzi \& Polan, 1994; Nianogo et al., 1991) com silagem de milho. Entretanto, Keery et al. (1993) utilizando suplementação de lipideo observaram menor digestibilidade da MS $(52,1 \%)$.

\subsubsection{Digestibilidade da MO}

A digestibilidade da $M O$ não foi afetada $(P>0,05)$ pelo teor de $P B$ assim como pela fonte de proteína. Comparando farelo de soja com farelo de glúten de milho (Klusmeyer et al., 1990) ou com uréia (Santos et al., 1998) não foi observado efeito de fonte de proteina sobre a digestibilidade da MO, porém Lines \& Weiss (1996), verificaram efeito negativo da uréia sobre a digestibilidade da MO em comparação com o farelo de soja em dieta contendo alfafa.

\subsubsection{Digestibilidade da PB}

A digestibilidade aparente da $\mathrm{PB}$ da dieta $\mathrm{C}$ foi inferior $(\mathrm{P}<0,05)$ às dietas U, FS e FGM. A menor digestibilidade do tratamento $C$ se deve ao menor teor de $\mathrm{PB}$ da dieta $(13,4 \%)$ comparado aos demais tratamentos $(16,5 \%)$, havendo efeito de teor de PB sobre a digestibilidade da PB, similar ao reportado por Klusmeyer et al. (1990).

O tratamento ST foi semelhante ao tratamento $C$ e inferior $(P<0,05)$ aos tratamentos U, FS e FGM. Provavelmente a tostagem da soja super protegeu a proteina, tornando-a menos disponivel à digestão (Reddy et al., 1994).

Os valores de digestibilidade da PB de todos tratamentos foram iguais ou inferiores aos da maioria dos trabalhos publicados na literatura. 
Os valores de digestibilidade da PB observados em dieta com farelo de soja situam-se em torno de 73,7\% (Wohlt et al., 1991), 64,1\% (Nianogo et al,, 1991) e 61,5\% (Knapp et al., 1991), tendo silagem de milho como volumoso. Valor menor $(58,1 \%)$ foi encontrado por Keery et al. (1993), utilizando silagem de trigo com suplementação de lipideo.

Os valores de digestibilidade aparente da PB das dietas com soja tostada relatados na literatura, foram de $59,9 \%$ (Knapp et al., 1991) e 57,1\% (Dhiman et al., 1997). Scott et al. (1991) observaram valor de digestibilidade inferior ao encontrado, em torno de $48,9 \%$, atribuindo esta baixa digestibilidade aparente da $\mathrm{PB}$ à super proteção da proteína com o processamento de tostagem.

Em experimentos onde o farelo de glúten de milho foi utilizado, os valores de digestibilidade da PB encontrados foram 57,9\% (Nianogo et al., 1991), 70\% (Wohlt et al., 1991) e 51\% com a suplementação de lipídeo (Keery et al., 1993).

\subsubsection{Digestibilidade do Amido}

A digestibilidade do amido não foi afetada $(P>0,05)$ por fonte de proteína, semelhante ao reportado por Santos et al. (1998), que não observaram efeito da substituição do farelo de soja por uréia sobre a digestibilidade do amido. $O$ teor de $P B$ da dieta também não afetou $(P>0,05)$ a digestibilidade do amido.

A digestibilidade do amido do milho aumenta com a floculação. Plascencia \& Zinn encontraram digestibilidade aparente total do amido em torno de $92,8 \%$ para densidade de $390 \mathrm{~g} / \mathrm{L}$, $96,8 \%$ para $320 \mathrm{~g} / \mathrm{L}$ e $98,5 \%$ para $260 \mathrm{~g} / \mathrm{L}$. A densidade do milho floculado utilizada foi $360 \mathrm{~g} / \mathrm{L}$, apresentando digestibilidade do amido um pouco abaixo do esperado. 


\subsubsection{Digestibilidade do FDN}

O teor de PB da dieta e a fonte protéica não afetaram $(P>0,05)$ a digestibilidade aparente do FDN, concordando com os resultados de literatura, nos quais não foi identificado efeito de fonte de proteína quando o farelo de soja foi comparado com farelo de glúten de milho (Nianogo et al., 1991; Keery et al., 1993; Klusmeyer et al., 1990) e com uréia (Santos et al., 1998).

Os valores de digestibilidade do FDN neste estudo foram inferiores aos normalmente encontrados na literatura. Nianogo et al. (1991) observaram valores de $56,5 \%$ com o uso de farelo de soja e $57,7 \%$ com farelo de glúten de milho. Keery et al. (1993) utilizando suplementação de lipideo, encontraram $48,9 \%$ para farelo de soja e $44,1 \%$ para farelo de glúten de milho.

De acordo com a revisão realizada por Nussio (1997) observou-se que o aumento da degradabilidade ruminal do amido diminuiu a digestibilidade da fibra. Fontes com alta degradabilidade ruminal, como milho floculado, podem reduzir a digestibilidade do FDN em 14,1\%. Simas (1995) utilizando grão processado e suplementação de lipídeo encontrou digestibilidade total do FDN próxima a 33,9\%, semelhante aos valores encontrados neste estudo.

\subsection{Ingestão de MS, produção e composição do leite}

Os resultados médios da ingestão de MS, produção de leite, eficiência alimentar e composição do leite estão ilustrados na Tabela 5 
Tabela 5. Efeito de fontes protéicas sobre a ingestão de MS, produção de leite eficiência alimentar e composição do leite.

\begin{tabular}{lcccccc}
\hline & \multicolumn{7}{c}{ Fontes de proteína } & \\
\cline { 2 - 6 } Item & C & $U$ & FS & ST & FGM & CV \% \\
\hline IMS (kg/d) & 19,31 & 19,57 & 17,99 & 18,46 & 19,21 & 8,19 \\
PL (kg/d) & 27,68 & 26,49 & 27,48 & 28,26 & 28,17 & 7,16 \\
PL a 3,5\% de G & 25,00 & 24,75 & 25,09 & 25,33 & 26,82 & 8,85 \\
PL a 3,5\% de G e 3,2\% de P & 25,12 & 24,87 & 25,08 & 25,11 & 26,81 & 8,41 \\
EA & 1,43 & 1,36 & 1,55 & 1,53 & 1,47 & 8,12 \\
Composição do leite & & & & & & \\
\% de proteína & 2,99 ab & 3,02 a & 2,92 ab & 2,80 b & 3,05 a & 3,52 \\
Kg de proteina & 0,82 & 0,81 & 0,81 & 0,79 & 0,86 & 7,85 \\
\% de gordura & 2,90 & 2,94 & 2,96 & 2,87 & 3,20 & 6,14 \\
Kg de gordura & 0,80 & 0,80 & 0,82 & 0,81 & 0,90 & 10,07 \\
\hline
\end{tabular}

IMS- Ingestão de MS, PL- Produção de Leite, PL a 3,5\% de G- Leite corrigido para 3,5\% de gordura, PL a $3,5 \%$ G e $3,2 \%$ P- Leite corrigido para $3,5 \%$ de gordura e $3,2 \%$ de proteina, EAEficiência Alimentar, \% proteina- teor de proteina do leite, \% gordura- teor de gordura do leite, $\mathrm{kg}$ de proteína- produção de proteína do leite, $\mathrm{kg}$ de gordura- produção de gordura do leite. Médias na mesma linha seguidas de letra diferem entre si $P<0,05$. Médias na mesma linha seguidas de letra diferem entre si $P<0,05$.

\subsubsection{Ingestão de MS}

Não houve $(P>0,05)$ efeito de fonte de proteina sobre a IMS, concordando com a maioria dos trabalhos de literatura, nos quais não foi identificado efeito de fonte protéica quando o farelo de soja foi comparado com a soja tostada (Mielke \& Schingoethe, 1981; Ruegsegger \& Schultz, 1985; Knapp et al., 1991; Bernard et al., 1992; Tice et al., 1993; McNiven et al., 1994), com o farelo de glúten de milho (Annexstad et al., 1987; Nianogo et al., 1991; Robinson et al., 1991, Price et al., 1988, Higginbotham et al., 1989, Taylor et al., 1991; Berzaghi \& Polan, 1991, Klusmeyer et al., 1990; Wohlt et al., 1991; Arieli et al., 1996) e com a uréia (Broderick 1986; Broderick et al., 1993, Baterman et al. 1994, Baker et al., 1995, Lines \& Weiss, 1996).

$O$ teor de $P B$ da deita também não alterou $(P>0,05)$ a IMS. A dieta controle com $13,4 \%$ de PB não diferiu estatisticamente dos demais tratamentos, que apresentavam teores de PB próximos à $16,5 \%$ de PB. 
Segundo Santos et al. (1998), o aumento do teor de PB da dieta de 12 a $13 \%$ para 15 a 17\% tem aumentado a produção de leite de vacas produzindo ao redor de $30 \mathrm{~kg} / \mathrm{d}$, devido principalmente a uma maior IMS, Quando a IMS permanece inalterada, dificilmente ocorre aumento em produção de leite.

\subsubsection{Produção de leite}

A produção de leite, o leite corrigido para gordura e o corrigido para gordura e proteína não foram afetados $(P>0,05)$ pela fonte de proteína e pelo teor de PB da dieta.

Os benefícios da suplementação com fontes ricas em PNDR não foram comprovados, concordando com Santos (1996), o qual não observou diferença de produção de leite em $82 \%$ das comparações onde o farelo de soja foi parcial ou totalmente substituído por fontes ricas em PNDR.

Nos experimentos relatados na literatura, não foi encontrado diferença de produção de leite ao compararem o farelo de soja com a soja tostada (Baker et al., 1986; Voss et al., 1988; Bernard et al., 1992; McNiven et al., 1994; Pires et al., 1996), com o farelo de glúten de milho (Nianogo et al., 1991; Keery et al., 1993; Annexstad et al., 1987; Price et al., 1988; . Robinson et al., 1991; Higginbotham et al., 1989; Wohlt et al. , 1991; Arieli et al., 1996), e com a uréia (Casper \& Schingoethe, 1986; Johnson et al., 1987; Casper et al., 1990; Baterman et al., 1994; Baker et al., 1995; Broderick et al., 1993; Lines \& Weiss,1996; Santos et al., 1995; . Santos et al., 1998).

Annexstad et al. (1987) afirmaram que dietas com proteina de alta degradabilidade ruminal podem apresentar produções de leite iguais ou superiores à fontes de proteína rica em PNDR, podendo a proteina protegida não acarretar nenhum benefício sobre animais com altas ingestões de alimento e taxas de passagens, como é o caso de vacas de elevada produção de leite.

Santos et al. (1998) sugeriram que vacas alimentadas com dietas ricas em amido degradável no rúmen poderiam usar fontes protéicas ricas em PDR 
ou NNP com maior eficiência e que, devido à maior sintese de PM nessas dietas, as chances de resposta à suplementação com fontes ricas em PNDR seriam menores.

\subsubsection{Eficiência alimentar}

A eficiência alimentar não foi alterada $(P>0,05)$ por fonte protéica e teor de PB na dieta.

\subsubsection{Composição do leite}

\subsubsection{Proteína do leite}

A porcentagem de proteína do leite e a produção de proteína do leite não foram alterados $(P>0,05)$ pelo teor de $P B$ da dieta $(13,4 \% \times 16,5 \%)$.

O tratamento ST apresentou porcentagem de proteina do leite inferior $(P<0,05)$ aos tratamentos $U$ e $F G M$ e similar ao $C$ e FS. Na maioria dos experimentos (Baker et al., 1986; Mohamed et al., 1988; Voss et al., 1988; Faldet \& Satter, 1991; Knapp et al., 1991; McNiven et al., 1994; Pires et al., 1996) onde a soja tostada foi comparada ao farelo de soja, a porcentagem de proteina do leite foi afetada negativamente com o uso de soja tostada, sendo atribuído em parte à suplementação de lipídeo. No presente trabalho, utilizouse caroço de algodão como fonte de lipídeo nas demais dietas que foram comparadas ao tratamento ST, eliminando o efeito da suplementação de lipídeo.

O processo de tostagem da soja foi provavelmente o responsável pela redução da porcentagem de proteina do leite no tratamento ST, super protegendo a proteina da soja e afetando a disponibilidade nutricional de alguns AA, como Lis (Faldet et al., 1991) e Met (Armentano et al., 1997). Os suplementos baixos ou desbalanceados em Lis e Met reduzem a síntese de proteina do leite (Schwab, 1994). 
A maioria dos experimentos não observaram efeito de fonte protéica sobre o teor de proteína do leite quando compararam o farelo de soja com farelo de glúten de milho (Price et al., 1988; Annexstad et al., 1987; Nianogo et al., 1991; Robinson et al., 1991; Higginbotham et al., 1989; Taylor et al.,1991; Berzaghi \& Polan , 1991; Wohlt et al., 1991; Arieli et al., 1996; Cozzi \& Polan, 1994) e o farelo de soja com uréia (Casper \& Schingoethe, 1986; Casper et al., 1990; Johnson et al., 1987; Santos et al., 1998; Baterman et al., 1994; Baker et al., 1995; Broderick et al., 1993; Lines \& Weiss,1996). Entretanto, em dietas contendo silagem de milho como única fonte de volumoso, a inclusão de níveis elevados de farelo de glúten de milho reduziu o teor de proteína do leite em relação ao farelo de soja (Polan et al., 1991).

A produção de proteína do leite não sofreu efeito $(P<0,05)$ de fonte de proteína, a menor porcentagem da proteína do leite do tratamento ST foi diluída com o aumento numérico da produção de leite.

\subsubsection{Gordura do leite}

O teor e produção de gordura do leite não foram afetados $(P>0,05)$ pelo teor de PB na dieta e fonte de proteína. O mesmo foi observado na maioria dos resultados reportados em experimentos de literatura, quando o farelo de soja foi comparado à soja tostada (Mohamed et al., 1988; Bernard et al., 1992; McNiven et al., 1994; Pires et al., 1996), ao farelo glúten de milho (Annexstad et al., 1987; Nianogo et al., 1991; Robinson et al., 1991; Higginbotham et al., 1989; Taylor et al., 1991; Berzaghi \& Polan , 1991; Wohlt et al., 1991; Cozzi \& Polan, 1994) e à uréia (Casper \& Schingoethe, 1986; Casper et al., 1990; Johnson et al., 1987; Baterman et al., 1994; Baker et al., 1995; Broderick et al., 1993; Lines \& Weiss, 1996; Santos et al., 1998). 


\subsection{Parâmetros ruminais}

\subsection{1 pH}

A Tabela 6 e a Figura 1 representam o efeito de fonte de proteína sobre os valores médios de $\mathrm{pH}$ dentro de cada periodo de coleta. Os tempos de $\mathrm{O}$ a 10 referem-se às coletas após o primeiro oferecimento da dieta das 6:00 h, enquanto os tempos de 12 a 22 referem-se às coletas após o segundo oferecimento da dieta as 18:00 h.

Como pode ser observado na Tabela 6 , o pH do rúmen não foi alterado $(P>0,05)$ por teor e fonte de proteina da dieta, corroborando os resultados experimentais, onde o farelo de soja foi comparado com a soja tostada (Mohamed et al., 1988; Knapp et al., 1991), com o farelo de glúten de milho (Higginbotham et al., 1989; Robinson et al., 1991; Klusmeyer et al., 1990) e com a uréia (Casper \& Schingoethe, 1986; Casper et al., 1990; Lines \& Weiss, 1996; Broderick, 1986). A Figura 1 ilustra bem o comportamento do $\mathrm{pH}$ no rúmen, onde os diferentes tratamentos tiveram similares tendências de linha de gráfico, confirmando que a fonte de proteína não afetou o pH ruminal.

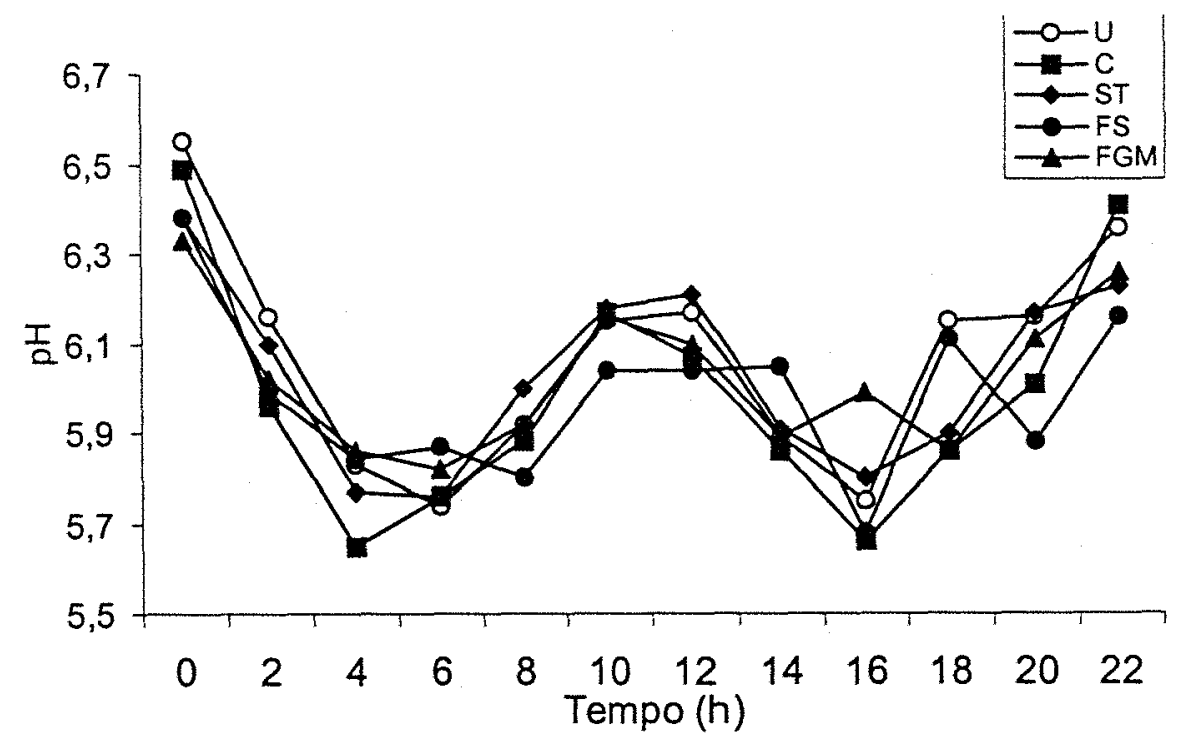

Figura 1. Efeito de fonte protéica sobre o pH ruminal dentro de cada tempo de coleta. 
Tabela 6. Comparação entre as médias do pH ruminal dos tratamentos dentro de cada tempo.

\begin{tabular}{lcccccc}
\hline & \multicolumn{6}{c}{ Fontes de proteina } \\
\cline { 2 - 5 } Tempo $(h)$ & $\mathrm{C}$ & $\mathrm{U}$ & $\mathrm{FS}$ & $\mathrm{ST}$ & FGM & CV \% \\
\hline Dieta 6:00h & & & & & & \\
0 & 6,49 & 6,55 & 6,38 & 6,38 & 6,33 & 2,23 \\
2 & 5,96 & 6,16 & 5,99 & 6,10 & 6,02 & 3,73 \\
4 & 5,65 & 5,83 & 5,84 & 5,77 & 5,86 & 4,21 \\
6 & 5,76 & 5,74 & 5,87 & 5,76 & 5,82 & 3,35 \\
8 & 5,88 & 5,92 & 5,80 & 6,00 & 5,92 & 3,33 \\
10 & 6,17 & 6,15 & 6,04 & 6,18 & 6,16 & 2,04 \\
Dieta 18:00h & & & & & & \\
12 & 6,07 & 6,17 & 6,04 & 6,21 & 6,10 & 4,55 \\
14 & 5,86 & 5,89 & 6,05 & 5,91 & 5,89 & 4,42 \\
16 & 5,66 & 5,75 & 5,68 & 5,80 & 5,99 & 3,81 \\
18 & 5,86 & 6,15 & 6,11 & 5,90 & 5,86 & 3,84 \\
20 & 6,01 & 6,16 & 5,88 & 6,17 & 6,11 & 4,36 \\
22 & 6,41 & 6,36 & 6,16 & 6,23 & 6,26 & 3,83 \\
\hline
\end{tabular}

\subsubsection{Amônia ruminal}

$\mathrm{Na}$ Tabela 7 e na Figura 2 estão representados os valores médios da concentração de nitrogênio amoniacal no fluido ruminal.

A quantidade de amônia ruminal necessária para maximizar o desempenho de vacas em lactação é discutível. Satter \& Slyter (1974) preconizaram valores de 2 a $3 \mathrm{mg}$ de $\mathrm{N}-\mathrm{NH}_{3} / 100 \mathrm{ml}$ de fluido ruminal para a sintese microbiana, enquanto Mehrez et al. (1977), citado pelo NRC (1985), sugeriram concentrações bem maiores em torno de 20 a $22 \mathrm{mg}$ para maximizar a fermentação ruminal e Poos et al. (1979a), citado pelo NRC (1985), sugerem que a maximização da digestão e ingestão dependem de concentrações de amônia mais elevadas que as propostas por Satter \& Slyter (1974). 
De acordo com o NRC (1988) teores de amônia ruminal maiores que 8 a $15 \mathrm{mg}$ de $\mathrm{N} / \mathrm{d}$ l são requeridas para maximizar a digestão da $\mathrm{MO}$ no rúmen de vacas lactantes e vacas que consomem inadequadas quantidades de energia podem apresentar excesso de amônia ruminal, altas concentrações de uréia plasmática e baixas concentrações de proteína no leite.

O tratamento $U$ apresentou maiores concentrações de amônia ruminal que os demais. Nos diversos experimentos (Casper \& Schingoethe, 1986; Lines \& Weiss, 1996; Broderick, 1986) onde o farelo de soja foi comparado com uréia, a concentração de amônia ruminal da dieta contendo uréia foi superior. A capacidade do tratamento $U$ elevar a concentração de amônia ruminal está evidente na Figura 2, podendo ser observado na Tabela 7 , que duas horas após o oferecimento da dieta (tempo 2 e tempo 14), o tratamento $U$ apresentou concentração de amônia ruminal superior $(P<0,05)$ aos demais tratamentos, atingindo $32,54 \mathrm{mg} / \mathrm{dl}$ após duas horas da alimentação. A porcentagem de proteína do leite do tratamento $U$ apresentou-se próxima a $3,02 \%$, não diferindo dos tratamentos C, FS e FGM, sendo inclusive superior ao ST.

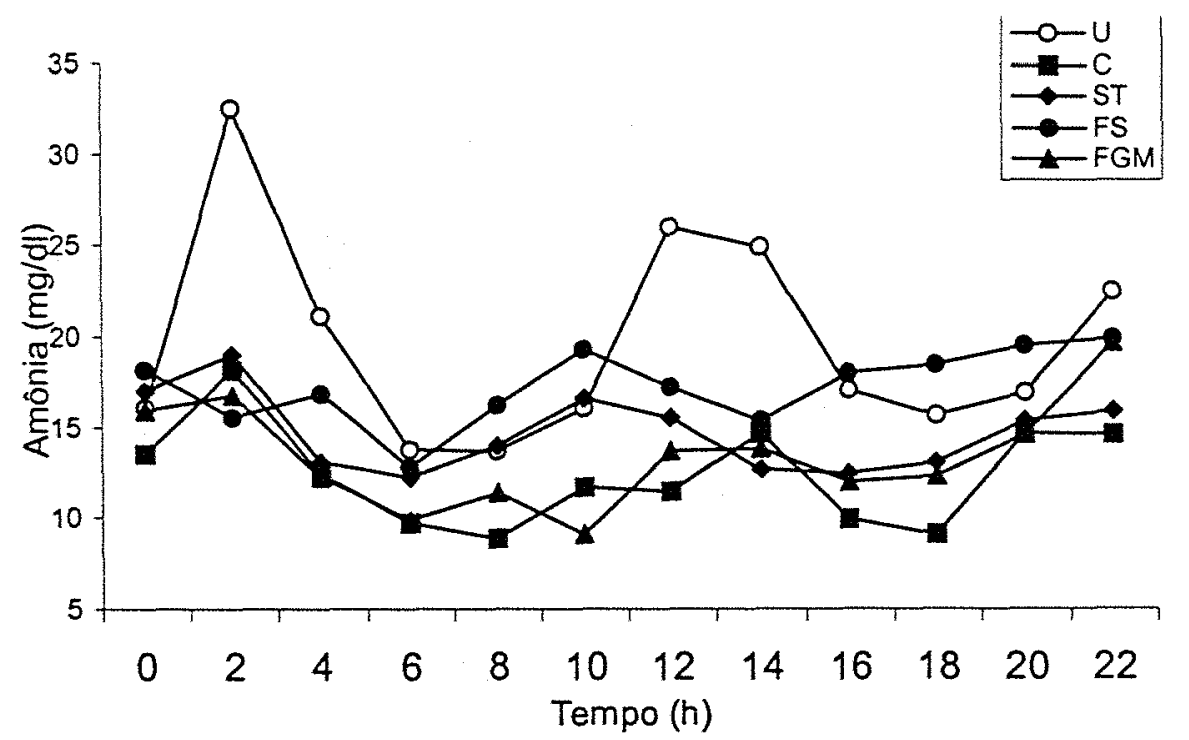

Figura 2. Efeito de fonte protéica sobre a concentração de amônia no líquido ruminal dentro de cada tempo de coleta. 
Tabela 7. Comparação entre as médias da concentração de amônia no líquido ruminal dos tratamentos dentro de cada tempo.

\begin{tabular}{|c|c|c|c|c|c|c|}
\hline \multirow[b]{2}{*}{ Tempo $(h)$} & \multicolumn{5}{|c|}{ Fontes de proteina } & \multirow[b]{2}{*}{ CV\% } \\
\hline & $\mathrm{C}$ & $U$ & FS & ST & FGM & \\
\hline \multicolumn{7}{|l|}{ Dieta 6:00h } \\
\hline 0 & 13,48 & 16,04 & 18,11 & 16,96 & 15,92 & 38,88 \\
\hline 2 & $18,12 b$ & $32,59 a$ & $15,53 \mathrm{~b}$ & $18,94 \mathrm{~b}$ & $16,76 \mathrm{~b}$ & 23,12 \\
\hline 4 & 12,40 & 21,15 & 16,82 & 13,08 & 12,24 & 51,95 \\
\hline 6 & 9,65 & 13,77 & 12,78 & 12,21 & 9,80 & 31,91 \\
\hline 8 & 8,82 & 13,64 & 16,23 & 13,95 & 11,34 & 32,28 \\
\hline 10 & $11,65 \mathrm{ab}$ & $16,07 a b$ & $19,30 \mathbf{a}$ & $16,59 \mathrm{ab}$ & $9,09 \mathrm{~b}$ & 32,60 \\
\hline \multicolumn{7}{|c|}{ Dieta 18:00h } \\
\hline 12 & 11,46 & 26,02 & 17,23 & 15,53 & 13,64 & 46,89 \\
\hline 14 & $14,69 \mathrm{~b}$ & 24,92 a & $15,33 b$ & $12,64 b$ & $13,83 \mathrm{~b}$ & 20,84 \\
\hline 16 & 9,92 & 17,08 & 17,95 & 12,41 & 11,97 & 33,60 \\
\hline 18 & 9,08 & 15,70 & 18,42 & 13,05 & 12,31 & 41,56 \\
\hline 20 & 14,64 & 16,86 & 19,48 & 15,34 & 14,56 & 22,64 \\
\hline 22 & 14,59 & 22,46 & 19,85 & 15,92 & 19,66 & 30,11 \\
\hline
\end{tabular}

Médias na mesma linha seguidas de letra diferem entre si $P<0,05$.

A suplementação de fontes ricas em PNDR como nos tratamentos ST e FGM não reduziram $(P>0,05)$ a concentração ruminal de $\mathrm{N}^{-N_{3}}$ em comparação ao $\mathrm{FS}$, porém os valores numéricos para os tratamentos ST e FGM foram sempre inferiores. Os tratamentos C, ST, FS e FGM não diferiram entre si nos diferentes tempos, com exceção do tempo 10, onde o FGM foi inferior $(P<0,05)$ ao FS.

A concentração de amônia ruminal com farelo de glúten de milho e com farelo de soja foram similares em alguns experimentos (Higginbotham et al., 1989; Robinson et al., 1991) e superior para o farelo de soja em outros (Klusmeyer et al., 1990; Price et al., 1988; Annexstad et al., 1987).

O FS não foi diferente da ST, apresentando-se similar aos trabalhos de literatura (Mohamed et al., 1988; Knapp et al., 1991). 


\subsection{3 Ácidos Graxos Voláteis}

\subsubsection{Concentração de AGV total}

As médias das concentrações molares do AGV totais dos tratamentos estão representadas na Tabela 8 e na Figura 3 . Em quase todos os tempos avaliados (Tabela 8 ), a fonte e o teor de proteina não alteraram $(P>0,05)$ a concentração molar de AGV total. Diferenças $(P<0,05)$ foram observadas. apenas nos tempos 0,12 e 14 .

No tempo 0, o FGM apresentou concentração molar de AGV total maior $(P<0,05)$ que o FS e U. A diferença em relação ao $F S$ poderia ser devido à menor porcentagem de amido do tratamento FS (Tabela 3 ), entretanto, o tratamento $U$ contém proporção de milho floculado maior do que o FGM.

A concentração molar de AGV total do tratamento $S T$ foi maior $(P<0,05)$ do que a do tratamento FS no tempo 18 e a concentração molar de AGV total do tratamento $U$ foi superior $(P<0,05)$ ao tratamento $F S$ no tempo 12 e 18. A menor capacidade do tratamento FS em elevar a concentração molar de AGV total pode ser atribuída à menor porcentagem de amido (Tabela 3) da dieta FS $(18,32 \%)$ em relação aos tratamentos ST $(24,27 \%)$ e $U(24,68 \%)$. Arieli et al. (1996) observaram que dietas com alto teor de MODR comparada à dietas com baixo teor de MODR tiveram a concentração molar de AGV total aumentada em $24 \%$.

As fontes de proteina farelo de soja e farelo de glúten de milho avaliadas em dieta a base de alfafa não alteraram a concentração molar de AGV total (Higginbotham et al., 1989; Robinson et al., 1991), a base de silagem de milho, o farelo de soja apresentou maior concentração molar de AGV total do que o farelo de glúten de milho (Klusmeyer et al., 1990; Price et al., 1988) indicando maior extensão de fermentação ruminal para o tratamento farelo de soja. Arieli et al. (1996) ao relacionarem teor de MODR e PDR da dieta com 
concentração molar de AGV total, encontraram maior influência do teor de MODR do que PDR.

Casper \& Schingoethe (1986), Casper et al. (1990) e Lines \& Weiss (1996) não observaram efeito de fonte de proteína sobre concentração molar de AGV total, quando compararam FS em substituição parcial ou total por U.

Mohamed et al., 1988 e Knapp et al., 1991 não observaram diferenças entre as concentrações molares de AGV totais ao compararem farelo de soja e soja tostada, indicando que a adição de soja tostada não afetou a fermentação ruminal.

Tabela 8. Comparação entre as médias da concentração molar do total de AGV no líquido ruminal dos tratamentos dentro de cada tempo.

\begin{tabular}{|c|c|c|c|c|c|c|}
\hline \multirow[b]{2}{*}{ Tempo (h) } & \multicolumn{5}{|c|}{ Fontes de proteina } & \multirow[b]{2}{*}{$\mathrm{CV} \%$} \\
\hline & C & $U$ & FS & ST & FGM & \\
\hline \multicolumn{7}{|l|}{ Dieta 6:00h } \\
\hline 0 & $133,58 a b$ & $122,17 \mathrm{~b}$ & $124,46 b$ & $135,32 a b$ & $179,83 \mathrm{a}$ & 19,50 \\
\hline 2 & 147,17 & 179,37 & 149,95 & 165,68 & 132,77 & 21,02 \\
\hline 4 & 158,64 & 162,34 & 135,45 & 146,49 & 139,72 & 11,95 \\
\hline 6 & 144,65 & 141,49 & 129,31 & 132,95 & 135,69 & 13,42 \\
\hline 8 & 164,87 & 138,27 & 128,34 & 125,93 & 146,83 & 23,80 \\
\hline 10 & 124,61 & 133,40 & 122,34 & 146,51 & 126,93 & 15,34 \\
\hline \multicolumn{7}{|c|}{ Dieta 18:00h } \\
\hline 12 & $129,00 \mathrm{ab}$ & $150,98 \mathbf{a}$ & $115,50 \mathrm{~b}$ & $127,39 a b$ & $126,39 b$ & 9,13 \\
\hline 14 & 139,75 & 144,39 & 133,50 & 147,71 & 159,60 & 15,95 \\
\hline 16 & 150,29 & 163,21 & 151,68 & 152,33 & 145,35 & 9,45 \\
\hline 18 & $133,35 a b$ & $138,06 \mathbf{a}$ & $105,51 \mathrm{~b}$ & $139,51 \mathbf{a}$ & $126,83 a b$ & 11,47 \\
\hline 20 & 154,85 & 136,51 & 140,86 & 150,31 & 118,98 & 18,56 \\
\hline 22 & 133,88 & 145,71 & 115,38 & 141,01 & 123,03 & 23,56 \\
\hline
\end{tabular}

Médias na mesma linha seguidas de letra diferem entre si $P<0,05$. 


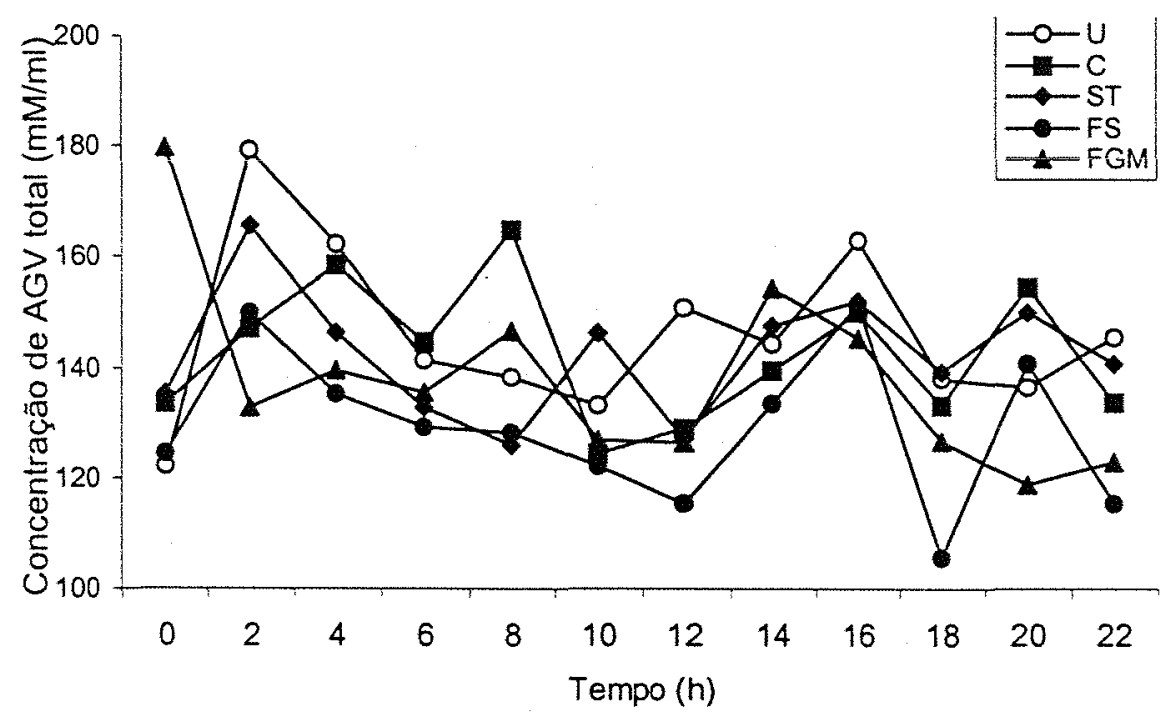

Figura 3. Efeito de fonte protéica sobre a concentração molar do total de AGV no liquido ruminal dentro de cada tempo de coleta.

\subsubsection{Porcentagem molar de acetato}

A Tabela 9 e Figura 4 apresentam as médias de porcentagem molar de acetato em cada tempo de coleta.

$\mathrm{Na}$ maioria dos tempos analisados, a porcentagem molar de acetato não foi afetada $(P>0,05)$ por fonte protéica e teor de $P B$ na dieta, concordando com os resultados encontrados em outros experimentos. Houve efeito $(P<0,05)$ dos tratamentos apenas no tempo 12. O tratamento FS apresentou maior porcentagem molar de acetato do que o tratamento $\mathrm{C}$, provavelmente devido à menor concentração de amido do tratamento FS (Tabela 3). Arieli et al. (1996) relataram redução de $8 \%$ na concentração molar de acetato em dietas ricas em MODR comparadas às dietas pobres em MODR.

Mohamed et al. (1988) e Knapp et al. (1991) não encontraram diferença entre as porcentagens molares de acetato dos tratamentos farelo de soja e soja tostada e Higginbotham et al. (1989), Robinson et al. (1991), Klusmeyer et al. (1990), Annexstad et al. (1987) e Arieli et al. (1996) também não encontraram 
efeito de fonte protéica quando compararam farelo de soja e farelo de glúten de milho.

Nos experimentos onde farelo de soja foi comparado com uréia, os resultados não foram consistentes. Casper et al. (1990) não encontraram diferenças entre dietas contendo farelo de soja ou uréia, mas Casper \& Schingoethe (1986) constataram vantagem para o farelo de soja e Broderick (1986) vantagem para a dieta contendo uréia.

Tabela 9. Comparação entre as médias das porcentagens molares de acetato dos tratamentos dentro de cada tempo.

\begin{tabular}{lllllll}
\hline & \multicolumn{6}{c}{ Fontes de proteina } \\
\cline { 2 - 5 } Tempo $(h)$ & $\mathrm{C}$ & $\mathrm{U}$ & $\mathrm{FS}$ & $\mathrm{ST}$ & $\mathrm{FGM}$ & CV \% \\
\hline Dieta 6:00h & & & & & & \\
0 & 62,53 & 61,58 & 59,37 & 61,24 & 60,77 & 3,69 \\
2 & 61,50 & 59,85 & 58,62 & 58,85 & 59,49 & 3,85 \\
4 & 60,16 & 61,54 & 60,03 & 61,17 & 60,35 & 4,12 \\
6 & 60,68 & 58,44 & 61,02 & 61,00 & 61,02 & 4,04 \\
8 & 60,59 & 60,73 & 59,22 & 59,73 & 59,84 & 2,64 \\
10 & 60,61 & 60,48 & 61,89 & 63,23 & 60,63 & 3,53 \\
Dieta 18:00h & & & & & & \\
12 & $59,09 \mathrm{~b}$ & 61,05 ab & $62,65 \mathrm{a}$ & $60,46 \mathrm{ab}$ & $59,33 \mathrm{~b}$ & 2,68 \\
14 & 60,48 & 60,56 & 62,41 & 61,20 & 60,75 & 2,44 \\
16 & 60,78 & 61,24 & 60,90 & 61,93 & 60,50 & 2,14 \\
18 & 61,08 & 61,18 & 63,02 & 61,17 & 59,70 & 3,17 \\
20 & 61,69 & 61,25 & 60,94 & 60,79 & 60,31 & 2,84 \\
22 & 62,76 & 62,22 & 61,81 & 61,53 & 61,56 & 4,24 \\
\hline
\end{tabular}

Médias na mesma linha seguidas de letra diferem entre si $P<0,05$. 


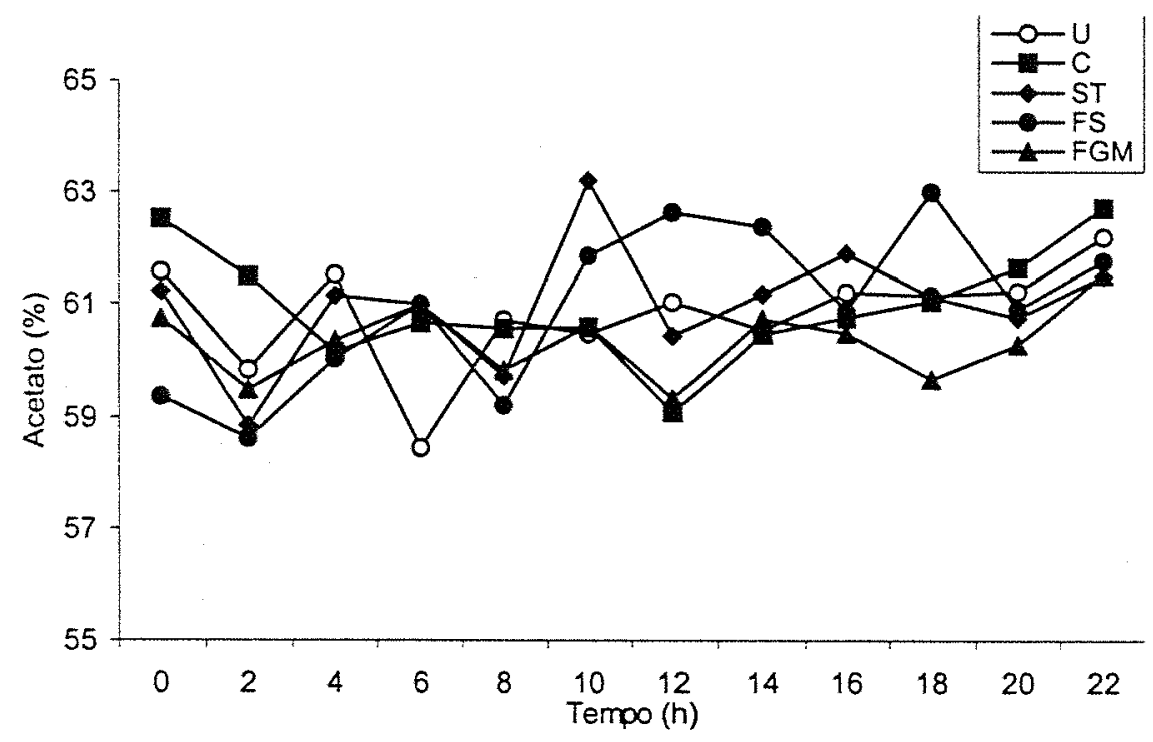

Figura 4. Efeito de fonte protéica sobre a porcentagem molar de acetato dentro de cada tempo de coleta.

\subsubsection{Porcentagem molar de propionato}

As médias das porcentagens molares de propionato dos diferentes tratamentos estão apresentadas na Tabela 10 e Figura 5.

A porcentagem molar do propionato foi alterada $(P<0,05)$ pelos tratamentos apenas no tempo 0. O FS foi superior ao tratamento $C$ e ST, enquanto o ST foi inferior também ao FGM. Considerando a menor porcentagem de amido do tratamento FS em relação aos tratamentos C e ST (Tabela 3), a maior porcentagem de propionato do tratamento FS contradiz o reportado por Arieli et al. (1996), os quais observaram aumento de $17 \%$ na porcentagem de propionato em dietas contendo maior quantidade de MODR. A menor porcentagem molar de propionato do tratamento ST pode ser atribuída à baixa digestibilidade da MO (Tabela 4 ) deste tratamento, a qual foi afetada pelo processo de tostagem (Reddy et al., 1994).

No geral, as fontes de proteína não afetaram a porcentagem molar de propionato, estando de acordo com a maioria dos resultados apresentados em 
literatura. Diferenças não foram observadas por Mohamed et al. (1988) e Knapp et al.(1991), comparando farelo de soja e soja tostada, por Higginbotham et al. (1989), Robinson et al. (1991), Klusmeyer et al. (1990), Annexstad et al. (1987) e Arieli et al. (1996), comparando farelo de soja e farelo de glúten de milho e por Casper et al. (1990), comparando farelo de soja e uréia. Apenas Casper \& Schingoethe (1986) constataram aumento e Broderick (1986) redução na proporção molar de propionato com a substituição de farelo de soja por uréia.

Tabela 10. Comparação entre as médias das porcentagens molares de propionato dos tratamentos dentro de cada tempo.

\begin{tabular}{llllllr}
\hline & \multicolumn{5}{c}{ Fontes de proteina } & \\
\cline { 2 - 5 } Tempo $(h)$ & \multicolumn{1}{c}{$\mathrm{C}$} & $\mathrm{U}$ & $\mathrm{FS}$ & $\mathrm{ST}$ & $\mathrm{FGM}$ & CV $\%$ \\
\hline Dieta 6:00h & & & & & & \\
0 & 19,84 bc & 20,62 abc & 22,91 a & 19,37 c & 21,95 ab & 6,04 \\
2 & 20,46 & 23,26 & 22,79 & 22,80 & 20,65 & 10,17 \\
4 & 22,05 & 20,98 & 21,80 & 22,06 & 21,33 & 11,65 \\
6 & 22,01 & 21,41 & 20,46 & 20,60 & 19,35 & 18,65 \\
8 & 22,75 & 19,13 & 21,11 & 20,98 & 21,07 & 11,33 \\
10 & 19,44 & 22,14 & 21,24 & 19,93 & 21,56 & 9,30 \\
Dieta 18:00h & & & & & & \\
12 & 22,67 & 20,93 & 19,47 & 20,88 & 22,38 & 9,01 \\
14 & 21,68 & 20,58 & 21,03 & 21,08 & 19,96 & 11,52 \\
16 & 22,48 & 19,85 & 21,33 & 20,95 & 20,38 & 12,25 \\
18 & 21,81 & 20,75 & 19,06 & 21,42 & 20,14 & 7,62 \\
20 & 20,32 & 20,65 & 19,99 & 20,58 & 19,16 & 7,57 \\
22 & 18,97 & 19,68 & 19,72 & 19,38 & 18,53 & 8,74 \\
\hline
\end{tabular}

Médias na mesma linha seguidas de letra diferem entre si $P<0,05$. 


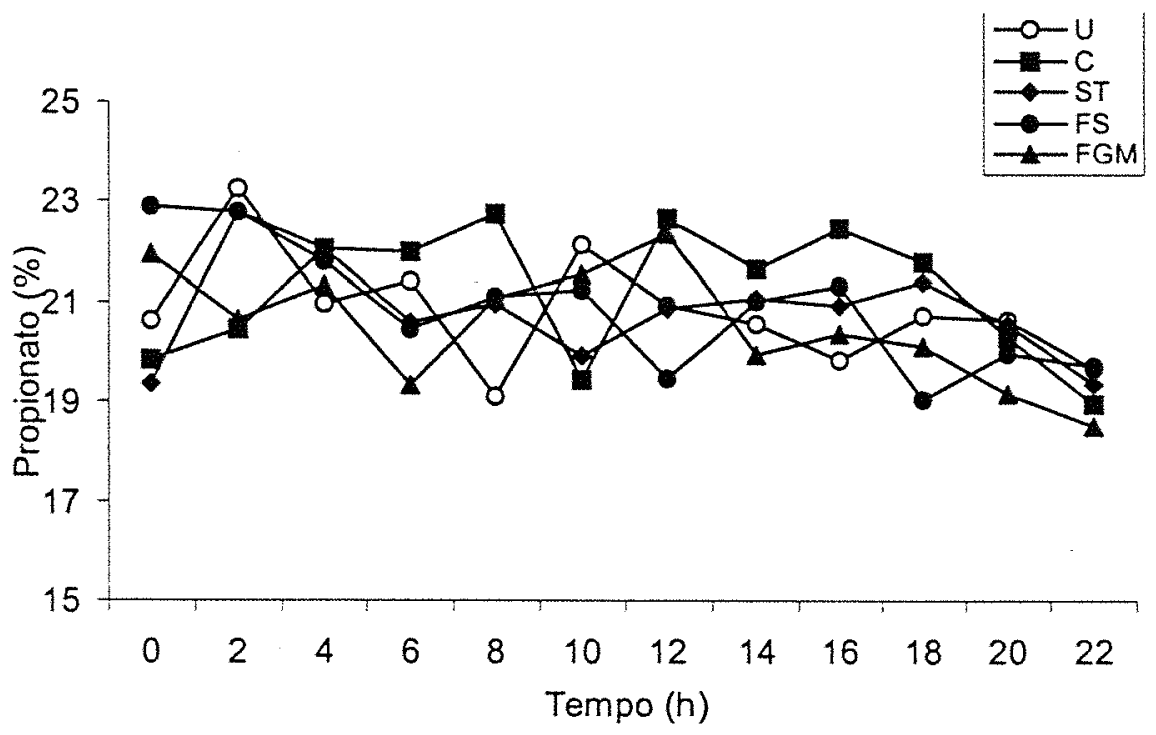

Figura 5. Efeito de fonte protéica sobre a porcentagem molar de propionato dentro de cada tempo de coleta.

\subsubsection{Relação acetato:propionato}

As médias da relação acetato:propionato dos tratamentos estão representadas na Tabela 11 e Figura 6.

A fonte e o teor de proteina não afetaram $(P>0,05)$ a relação acetato:propionato na maioria dos tempos analisados. Estes resultados são semelhante aos dados de literatura. Houve diferença apenas no tempo 0 , onde os tratamentos C e ST apresentaram maior relação acetato:propionato que o tratamento FS.

Mohamed et al. (1988) e Knapp et al. (1991) não encontraram diferença na relação acetato:propionato entre dietas com farelo de soja e soja tostada.

Higginbotham et al. (1989), Robinson et al. (1991), Klusmeyer et al. (1990), Annexstad et al. (1987) e Arieli et al. (1996) não observaram diferença entre farelo de soja e farelo de glúten de milho, apenas Price et al. (1988) encontraram maior relação acetato:propionato como o uso de farelo de soja. 


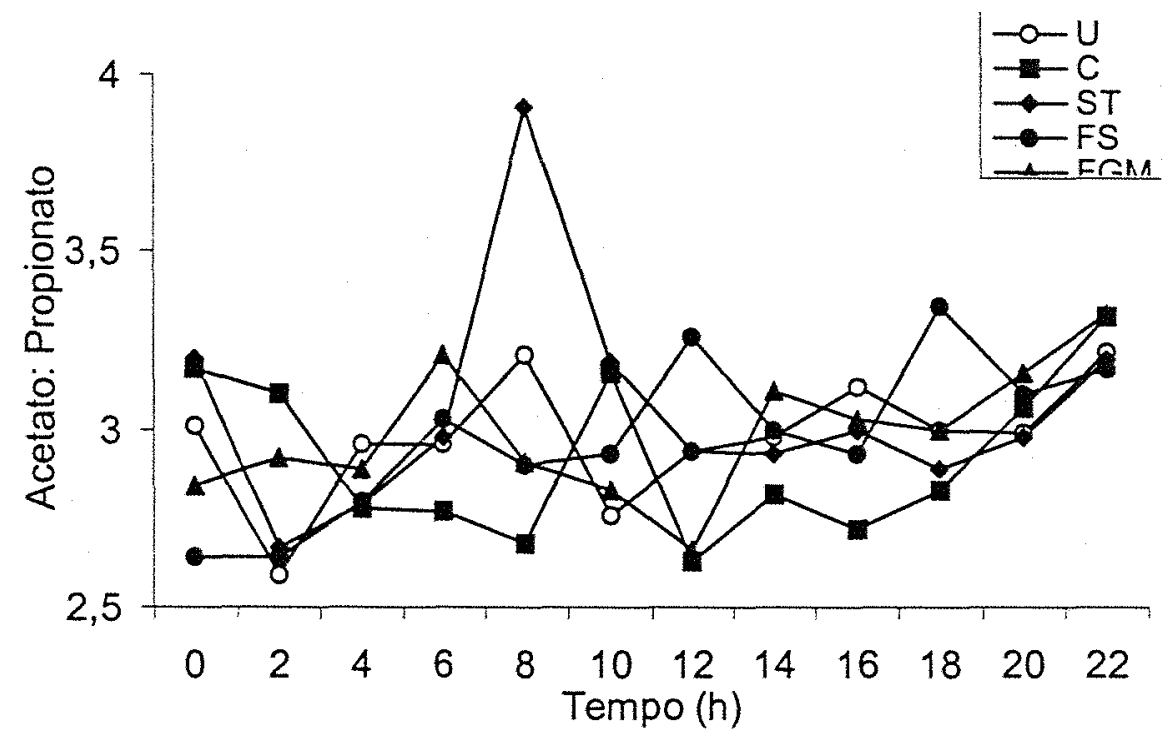

Figura 6. Efeito de fonte protéica sobre a relação acetato: propionato dentro de cada tempo de coleta.

Tabela 11. Comparação entre as médias da relação acetato: propionato dos tratamentos dentro de cada tempo.

\begin{tabular}{|c|c|c|c|c|c|c|}
\hline \multirow[b]{2}{*}{ Tempo (h) } & \multicolumn{5}{|c|}{ Fontes de proteina } & \multirow[b]{2}{*}{ CV \% } \\
\hline & C & U & FS & ST & FGM & \\
\hline \multicolumn{7}{|c|}{ Dieta 6:00h } \\
\hline 0 & $3,20 \mathrm{a}$ & $3,01 \mathrm{ab}$ & $2,64 \mathbf{b}$ & $3,20 \mathrm{a}$ & $2,84 a b$ & 7,02 \\
\hline 2 & 3,10 & 2,59 & 2,64 & 2,67 & 2,92 & 13,28 \\
\hline 4 & 2,78 & 2,96 & 2,80 & 2,79 & 2,89 & 14,34 \\
\hline 6 & 2,77 & 2,96 & 3,04 & 2,98 & 3,21 & 17,57 \\
\hline 8 & 2,68 & 3,21 & 2,90 & 2,91 & 2,91 & 11,55 \\
\hline 10 & 3,16 & 2,76 & 2,93 & 3,19 & 2,83 & 11,47 \\
\hline \multicolumn{7}{|c|}{ Dieta 18:00h } \\
\hline 12 & 2,63 & 2,94 & 3,26 & 2,94 & 2,66 & 10,23 \\
\hline 14 & 2,82 & 2,98 & 3,00 & 2,93 & 3,11 & 12,62 \\
\hline 16 & 2,72 & 3,12 & 2,93 & 3,00 & 3,03 & 14,41 \\
\hline 18 & 2,83 & 3,00 & 3,35 & 2,89 & 3,00 & 9,35 \\
\hline 20 & 3,06 & 2,99 & 3,10 & 2,98 & 3,16 & 8,82 \\
\hline 22 & 3,32 & 3,22 & 3,17 & 3,20 & 3,33 & 8,84 \\
\hline
\end{tabular}

Médias na mesma linha seguidas de letra diferem entre si $P<0,05$. 


\subsubsection{Porcentagem molar de butirato}

$\mathrm{Na}$ Tabela 12 e Figura 7 estão representadas as médias da porcentagem molar de butirato.

A fonte e teor de proteina não afetaram $(P>0,05)$ a porcentagem molar do butirato.

Também não foi observado efeito de fonte protéica sobre a porcentagem molar de butirato em outros experimentos que compararam farelo de soja com soja tostada (Mohamed et al., 1988; Knapp et al., 1991), farelo de soja com farelo de glúten de milho (Higginbotham et al., 1989; Robinson et al., 1991; Klusmeyer et al., 1990; Annexstad et al.; 1987; Arieli et al., 1996) e farelo de soja com uréia (Casper et al., 1990; Casper \& Schingoethe, 1986; Lines \& Weiss, 1996). Apenas Price et al. (1988) e Broderick (1986) encontraram maior porcentagem de butirato com o uso de farelo de soja do que farelo de glúten de milho ou uréia.

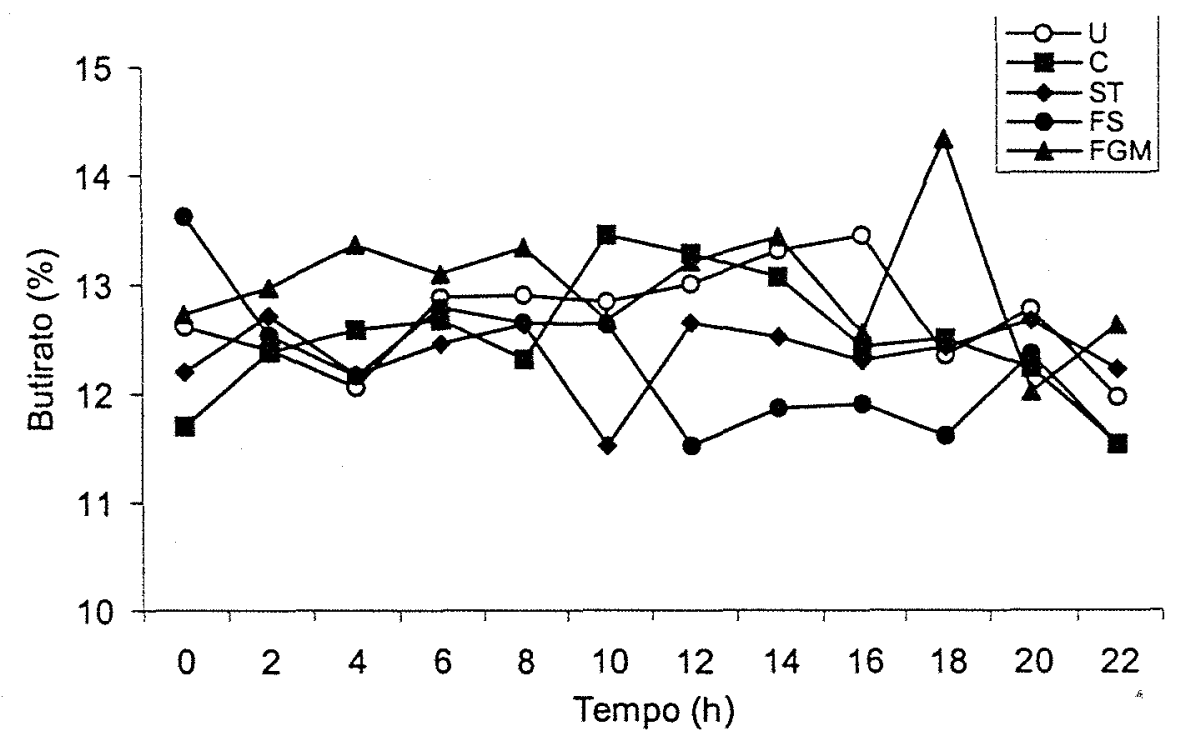

Figura 7. Efeito de fonte protéica sobre a porcentagem molar de butirato dentro de cada tempo de coleta. 
Tabela 12. Comparação entre as médias das porcentagens molares de butirato dos tratamentos dentro de cada tempo.

\begin{tabular}{lrrrrrr}
\hline & \multicolumn{5}{c}{ Fontes de proteina } & \\
\cline { 2 - 5 } Tempo $(h)$ & $\mathrm{C}$ & $\mathrm{U}$ & $\mathrm{FS}$ & $\mathrm{ST}$ & FGM & CV \% \\
\hline Dieta 6:00h & & & & & & \\
0 & 11,70 & 12,61 & 13,63 & 12,20 & 12,73 & 13,30 \\
2 & 12,39 & 12,41 & 12,59 & 12,79 & 12,98 & 9,79 \\
4 & 12,59 & 12,07 & 12,17 & 12,18 & 13,37 & 7,98 \\
6 & 12,68 & 12,89 & 12,79 & 12,46 & 13,10 & 9,48 \\
8 & 12,32 & 12,91 & 12,65 & 12,64 & 13,34 & 8,81 \\
10 & 13,46 & 12,85 & 12,64 & 11,53 & 12,68 & 11,05 \\
Dieta 18:00h & & & & & & \\
12 & 13,30 & 13,01 & 11,52 & 12,66 & 13,22 & 10,85 \\
14 & 13,08 & 13,32 & 11,87 & 12,53 & 13,45 & 9,19 \\
16 & 12,43 & 13,46 & 11,91 & 12,31 & 12,56 & 8,02 \\
18 & 12,51 & 12,36 & 11,61 & 12,44 & 14,34 & 12,36 \\
20 & 12,25 & 12,78 & 12,37 & 12,68 & 12,03 & 13,90 \\
22 & 11,54 & 11,98 & 11,54 & 12,23 & 12,64 & 14,49 \\
\hline
\end{tabular}

\subsubsection{Porcentagem molar de AGV de cadeia ramificada}

\subsection{Total de AGV ramificado}

Os AGV de cadeia ramificada são provenientes da deaminação e descarboxilação de AA de cadeia ramificada (leucina, isoleucina e valina), estando associados à digestão ruminal de proteina.

A porcentagem molar do total de AGV de cadeia ramificada não sofreu efeito $(P>0,05)$ de fonte e teor de proteína como pode ser observado na Tabela 13 e na Figura 8. 
Tabela 13. Comparação entre as médias da porcentagem do total de AGV de cadeia ramificada dos tratamentos dentro de cada tempo.

\begin{tabular}{|c|c|c|c|c|c|c|}
\hline \multirow[b]{2}{*}{ Tempo $(h)$} & \multicolumn{5}{|c|}{ Fontes de proteína } & \multirow[b]{2}{*}{$\mathrm{CV} \%$} \\
\hline & C & U & FS & ST & FGM & \\
\hline \multicolumn{7}{|l|}{ Dieta 6:00h } \\
\hline 0 & 5,12 & 5,19 & 5,34 & 4,80 & 4,54 & 14,31 \\
\hline 2 & 4,85 & 4,47 & 5,02 & 4,82 & 5,28 & 13,39 \\
\hline 4 & 4,40 & 4,60 & 5,01 & 4,59 & 4,15 & 20,85 \\
\hline 6 & 4,62 & 4,86 & 4,74 & 5,14 & 4,92 & 10,89 \\
\hline 8 & 4,32 & 4,81 & 5,02 & 5,04 & 4,95 & 15,44 \\
\hline 10 & 4,88 & 4,53 & 4,24 & 4,51 & 5,13 & 16,64 \\
\hline \multicolumn{7}{|c|}{ Dieta 18:00h } \\
\hline 12 & 4,92 & 4,22 & 5,37 & 5,20 & 5,06 & 16,59 \\
\hline 14 & 3,96 & 4,74 & 4,69 & 5,20 & 4,24 & 21,13 \\
\hline 16 & 4,30 & 4,66 & 4,87 & 4,01 & 4,83 & 21,75 \\
\hline 18 & 4,60 & 4,89 & 5,31 & 4,97 & 4,01 & 14,98 \\
\hline 20 & 4,93 & 5,33 & 5,72 & 5,15 & 5,71 & 13,70 \\
\hline 22 & 5,13 & 4,50 & 5,92 & 5,25 & 5,67 & 15,17 \\
\hline
\end{tabular}

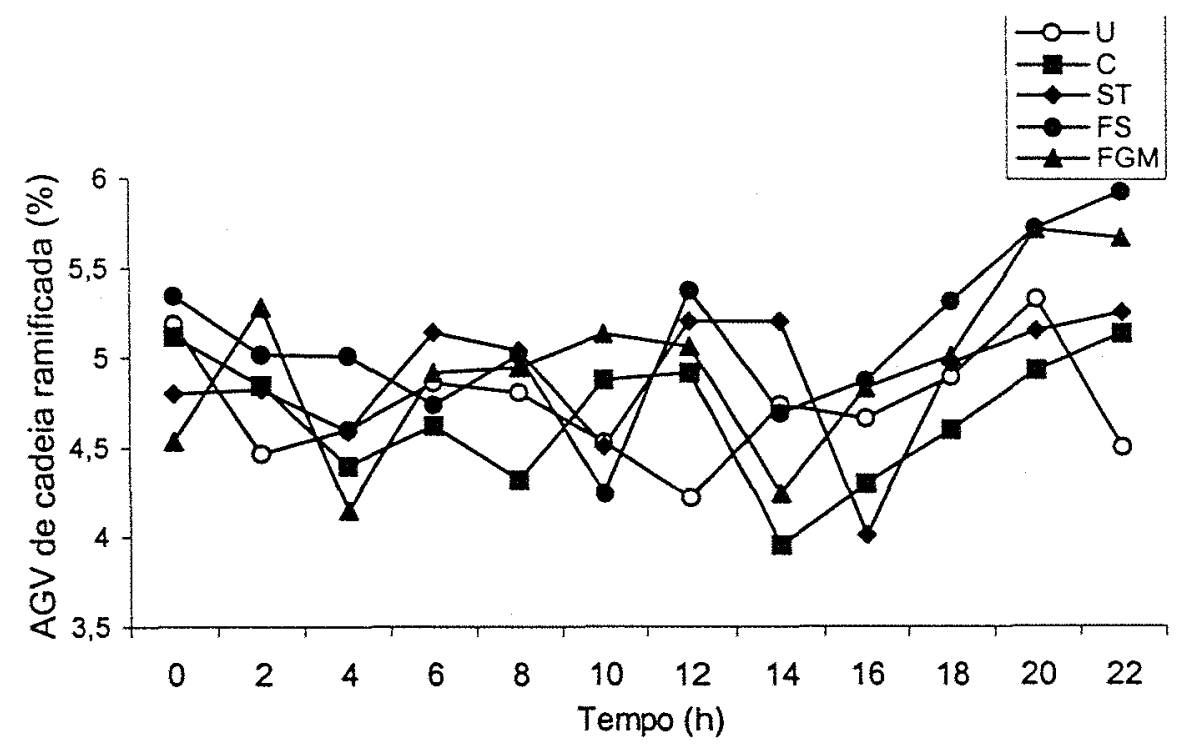

Figura 8. Efeito de fonte protéica sobre a porcentagem molar do total de AGV de cadeia ramificada dentro de cada tempo de coleta. 


\subsection{Porcentagem molar de isobutirato, isovalerato e valerato}

Os AGV de cadeia ramificada isovalerato (Tabela 14 e Figura 9) e valerato (Tabela 15 e Figura 10) não foram influenciados $(P>0,05)$ por fonte $e$ teor de proteína da dieta.

Tabela 14. Comparação entre as médias da porcentagem molar de isovalerato dos tratamentos dentro de cada tempo.

\begin{tabular}{|c|c|c|c|c|c|c|}
\hline \multirow[b]{2}{*}{ Tempo (h) } & \multicolumn{5}{|c|}{ Fontes de proteína } & \multirow[b]{2}{*}{$C \vee \%$} \\
\hline & C & U & FS & ST & FGM & \\
\hline \multicolumn{7}{|l|}{ Dieta 6:00h } \\
\hline 0 & 2,06 & 1,95 & 2,22 & 2,05 & 1,86 & 13,94 \\
\hline 2 & 1,81 & 1,71 & 2,06 & 1,90 & 2,12 & 16,53 \\
\hline 4 & 1,68 & 1,70 & 2,01 & 1,82 & 1,68 & 16,74 \\
\hline 6 & 1,84 & 1,77 & 1,87 & 2,16 & 1,94 & 13,47 \\
\hline 8 & 1,61 & 1,97 & 2,03 & 1,98 & 2,01 & 16,43 \\
\hline 10 & 1,82 & 1,72 & 1,80 & 1,85 & 2,14 & 15,77 \\
\hline \multicolumn{7}{|c|}{ Dieta 18:00h } \\
\hline 12 & 1,97 & 1,69 & 2,10 & 2,22 & 2,16 & 17,40 \\
\hline 14 & 1,56 & 1,85 & 2,02 & 2,05 & 1,69 & 16,25 \\
\hline 16 & 1,63 & 1,81 & 2,03 & 1,64 & 2,01 & 19,67 \\
\hline 18 & 1,77 & 1,90 & 2,11 & 2,02 & 2,04 & 12,10 \\
\hline 20 & 1,93 & 2,00 & 2,17 & 2,04 & 2,21 & 19,09 \\
\hline 22 & 1,92 & 1,81 & 2,37 & 2,02 & 2,21 & 12,31 \\
\hline
\end{tabular}




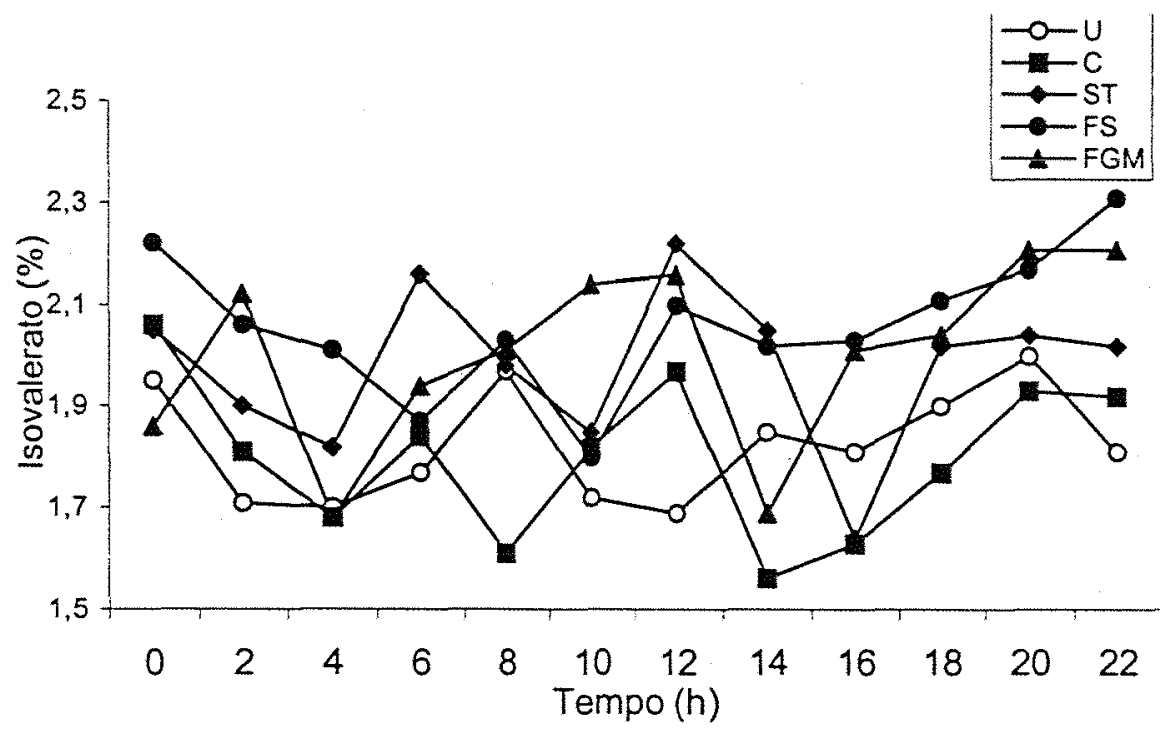

Figura 9. Efeito de fonte protéica sobre a porcentagem molar de isovalerato dentro de cada tempo de coleta.

Tabela 15. Comparação entre as médias da porcentagem molar de valerato dos tratamentos dentro de cada tempo.

\begin{tabular}{|c|c|c|c|c|c|c|}
\hline \multirow[b]{2}{*}{ Tempo $(h)$} & \multicolumn{5}{|c|}{ Fontes de proteina } & \multirow[b]{2}{*}{ CV \% } \\
\hline & C & $U$ & FS & ST & FGM & \\
\hline \multicolumn{7}{|l|}{ Dieta 6:00h } \\
\hline 0 & 2,42 & 2,20 & 2,19 & 1,90 & 1,91 & 23,37 \\
\hline 2 & 2,13 & 2,33 & 2,18 & 2,23 & 2,45 & 15,26 \\
\hline 4 & 2,34 & 2,14 & 2,30 & 2,18 & 1,91 & 26,63 \\
\hline 6 & 2,47 & 2,17 & 2,11 & 2,31 & 2,26 & 16,65 \\
\hline 8 & 2,21 & 2,04 & 2,20 & 2,36 & 2,14 & 18,44 \\
\hline 10 & 2,12 & 2,39 & 1,80 & 2,04 & 2,21 & 23,36 \\
\hline \multicolumn{7}{|l|}{ Dieta 18:00h } \\
\hline 12 & 1,86 & 2,26 & 2,41 & 2,25 & 2,17 & 22,36 \\
\hline 14 & 2,28 & 1,83 & 1,85 & 2,43 & 1,93 & 28,80 \\
\hline 16 & 2,22 & 2,12 & 2,11 & 1,84 & 2,22 & 26,41 \\
\hline 18 & 2,28 & 2,15 & 2,34 & 2,21 & 2,26 & 23,15 \\
\hline 20 & 2,54 & 2,23 & 2,67 & 2,33 & 2,67 & 17,38 \\
\hline 22 & 1,94 & 2,34 & 2,68 & 2,50 & 2,58 & 23,30 \\
\hline
\end{tabular}




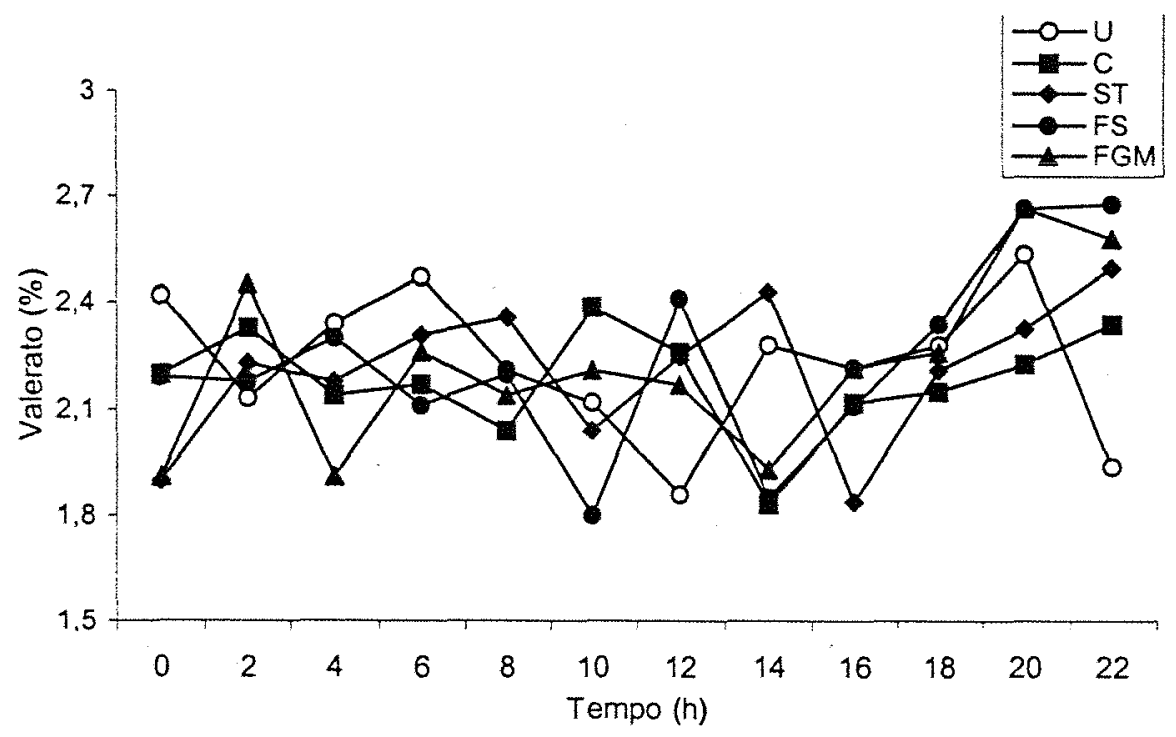

Figura 10. Efeito de fonte protéica sobre a porcentagem molar de valerato dentro de cada tempo de coleta.

As médias de porcentagem molar de isobutirato dos tratamentos estão representadas na Tabela 16 e Figura 11.

Houve efeito de fonte e teor de proteina sobre a porcentagem molar de isobutirato nos tempos $0,6,8,12$ e 18 .

O tratamento FS foi superior $(P<0,05)$ ao $F G M$ no tempo 0 e 12, provavelmente devido a própria característica do FGM, pois grande parte da proteína solúvel do FGM é removida durante o processamento do milho para a obtenção deste suplemento protéico (Clark et al., 1987), necessitando de um tempo maior para ocorrer a degradação da proteína, liberação de $A A$ ramificados e consequente formação de AGV de cadeia ramificada.

$O$ tratamento $U$ foi inferior $(P<0,05)$ ao $F S$ nos tempo 6, 8 e 18 e aos tratamentos C, ST, FGM no tempo 8 , semelhante ao reportado por Broderick (1986), implicando em um baixo conteúdo de proteína pré formada no rúmen com o uso de U. 
Tabela 16. Comparação entre as médias da porcentagem molar de isobutirato dos tratamentos dentro de cada tempo.

\begin{tabular}{|c|c|c|c|c|c|c|}
\hline \multirow[b]{2}{*}{ Tempo (h) } & \multicolumn{5}{|c|}{ Fontes de proteína } & \multirow[b]{2}{*}{ CV \% } \\
\hline & C & $U$ & FS & ST & FGM & \\
\hline \multicolumn{7}{|l|}{ Dieta 6:00h } \\
\hline 0 & $0,86 a b$ & $0,83 a b$ & $0,94 \mathbf{a}$ & $0,85 a b$ & $0,77 \mathrm{~b}$ & 7,90 \\
\hline 2 & 0,70 & 0,63 & 0,78 & 0,69 & 0,71 & 12,45 \\
\hline 4 & 0,58 & 0,55 & 0,71 & 0,59 & 0,55 & 26,40 \\
\hline 6 & $0,61 \mathbf{b}$ & $0,62 \mathrm{~b}$ & $0,77 \mathbf{a}$ & $0,67 a b$ & $0,72 a b$ & 8,70 \\
\hline 8 & $0,67 a$ & $0,62 \mathrm{~b}$ & $0,79 \mathbf{a}$ & $0,71 \mathrm{a}$ & $0,80 a$ & 14,69 \\
\hline 10 & 0,68 & 0,69 & 0,64 & 0,61 & 0,78 & 15,78 \\
\hline \multicolumn{7}{|l|}{ Dieta 18:00h } \\
\hline 12 & $0,86 a b$ & $0,83 a b$ & $0,94 \mathbf{a}$ & $0,85 a b$ & $0,77 \mathrm{~b}$ & 11,17 \\
\hline 14 & 0,70 & 0,63 & 0,78 & 0,69 & 0,71 & 24,51 \\
\hline 16 & 0,58 & 0,55 & 0,71 & 0,59 & 0,55 & 21,28 \\
\hline 18 & $0,61 \mathrm{~b}$ & $0,62 \mathrm{~b}$ & $0,77 \mathbf{a}$ & $0,67 a b$ & $0,72 a b$ & 18,14 \\
\hline 20 & 0,67 & 0,64 & 0,79 & 0,71 & 0,80 & 15,44 \\
\hline 22 & 0,68 & 0,69 & 0,64 & 0,61 & 0,78 & 19,03 \\
\hline
\end{tabular}

Médias na mesma linha seguidas de letra diferem entre si $P<0,05$.

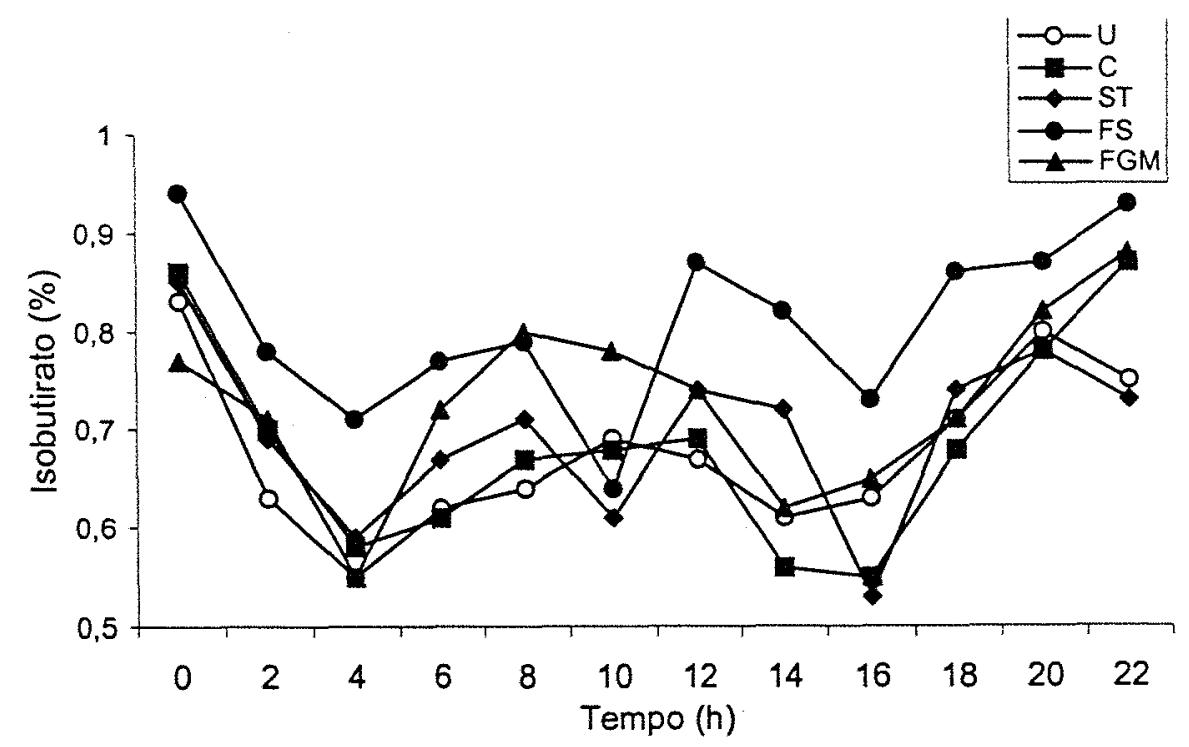

Figura 11. Efeito de fonte protéica sobre a porcentagem molar de isobutirato dentro de cada tempo de coleta. 


\subsubsection{Parâmetros sanguíneos}

\subsubsection{Concentração de uréia plasmática}

As médias de concentração de uréia plasmática estão presentes na Tabela 17 e Figura 12.

Os valores médios da concentração de uréia plasmática do tratamento $U$ não diferiram dos demais tratamentos somente no tempo 0 , antes do fornecimento da dieta. Três e seis horas após a ingestão de alimento, o tratamento $U$ apresentou maior $(P<0,05)$ concentração de uréia plasmática. No tempo 3 foi superior $(P<0,05)$ aos tratamentos $C$ e FS e no tempo 6, superior aos demais tratamentos. O aumento considerável da concentração de uréia plasmática do tratamento $U$ foi compativel ao aumento de concentração de amônia ruminal (Tabela 7 e Figura 2) duas horas após o fornecimento da dieta. De modo geral o tratamento $\mathrm{C}$ apresentou concentrações mais baixas de uréia plasmática nos tempos 3 e 6 em relação aos demais tratamentos, refletindo o menor teor de proteína da dieta e menor concentração de amônia no rúmen.

Higginbotham et al. (1989) e Robinson et al. (1991) observaram aumento na concentração de uréia plasmática com os aumentos de porcentagem de PB na dieta e de PDR, quando compararam farelo de soja e farelo de glúten de milho, mas Wohlt et al. (1991) e Cozzi \& Polan (1994) não constataram efeito de fonte de proteína sobre a concentração de uréia plasmática. Arieli et al. (1996) encontraram efeito de interação entre fonte de proteína e de carboidrato, observando aumento de $27 \%$ na concentração de uréia plasmática quando combinou-se dieta alta em PDR e baixa em MODR.

Experimentos onde o farelo de soja foi substituído parcialmente por uréia (Casper \& Schingoethe, 1986; Casper et al., 1990; Baker et al., 1995) não evidenciaram efeito de fonte de proteína sobre a concentração de uréia plasmática mas, quando em substituição total (Broderick et al., 1993; Lines \& 
Weiss, 1996), observou-se maior concentração de uréia plasmática nas dietas com uréia.

Concentrações de uréia plasmática superiores a $8-10 \mathrm{mg}$ de $\mathrm{N} / \mathrm{dl}$ são requeridas para maximizar a digestão da $M O$ no rúmen de vacas lactantes (NRC, 1988). Avaliando a digestibilidade total da MO (Tabela 4) observa-se que o tratamento $C$ apresenta numericamente a menor digestibilidade $(59,79 \%)$, coincidindo com a baixa concentração de uréia plasmática nos tempos 3 e 6 $(8,73$ e $7,08 \mathrm{mg}$ de $\mathrm{N} / \mathrm{dl})$.

Dieta com inadequada quantidade de energia pode ocasionar excesso de amônia ruminal, altas concentrações de uréia plasmática e baixas concentrações de proteina no leite (NRC, 1988). Entretanto, apesar do tratamento $U$ apresentar altas concentrações de amônia ruminal e de uréia plasmática horas após o oferecimento da dieta, a porcentagem de proteína do leite e a produção de leite não foram afetadas.

Tabela 17. Comparação entre as médias da concentração de uréia plasmática dos tratamentos dentro de cada tempo.

\begin{tabular}{lcccccc}
\hline & \multicolumn{6}{c}{ Fontes de proteína } \\
\cline { 2 - 6 } Tempo $(h)$ & C & U & FS & ST & FGM & CV \% \\
\hline Dieta 6:00h & & & & & & \\
0 & 12,26 & 11,10 & 12,70 & 15,74 & 12,18 & 23,69 \\
3 & $8,73 \mathbf{b}$ & $15,26 \mathbf{a}$ & $10,77 \mathbf{b}$ & $11,81 \mathbf{a b}$ & $12,53 \mathbf{a b}$ & 18,38 \\
6 & $7,08 \mathbf{c}$ & $17,78 \mathbf{a}$ & $11,90 \mathbf{b}$ & $11,58 \mathbf{b}$ & $13,06 \mathbf{b}$ & 17,13 \\
\hline
\end{tabular}

Médias na mesma linha seguidas de letra diferem entre si $P<0,05$. 


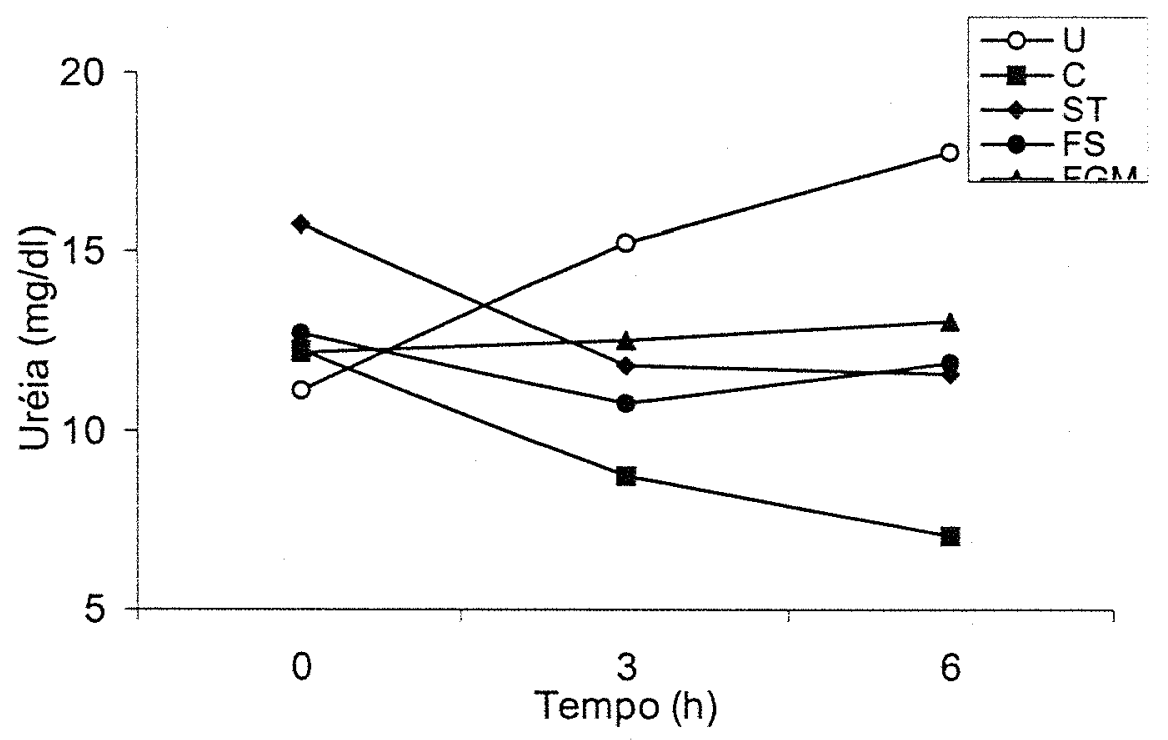

Figura 12. Efeito de fonte protéica sobre a concentração de uréia plasmática cada tempo de coleta.

\subsubsection{Concentração de glucose plasmática}

As médias da concentração de glucose plasmática apresentam-se na Tabela 18 e Figura 13.

A concentração de glucose plasmática não foi afetada $(P>0,05)$ por teor e fonte de proteína na dieta, concordando com os resultados de experimentos, onde o farelo de soja foi comparado com a soja tostada (Pires et al., 1996; Mohamed et al., 1988), com o farelo de glúten de milho (Higginbotham et al., 1989; Robinson et al., 1991) e com a uréia (Broderick et al., 1993).

Há citações de que um excesso de amônia ruminal poderia afetar o metabolismo de glucose (NRC, 1988); entretanto, apesar do tratamento $U$ ter apresentado altas concentrações de amônia no rúmen, a concentração de glucose plasmática manteve-se inalterada. 
Tabela 18. Comparação entre as médias da concentração de glucose plasmática dos tratamentos dentro de cada tempo.

\begin{tabular}{lrrrrrr}
\hline & \multicolumn{5}{c}{ Fontes de proteína } & \multirow{2}{*}{ Tempo $(h)$} \\
\cline { 2 - 6 } & $\mathrm{C}$ & $\mathrm{U}$ & $\mathrm{FS}$ & $\mathrm{ST}$ & FGM & CV \% \\
\hline Dieta 6:00h & & & & & & \\
0 & 46,48 & 43,42 & 55,44 & 48,78 & 46,64 & 18,73 \\
3 & 49,28 & 48,58 & 48,03 & 49,22 & 41,50 & 21,33 \\
6 & 52,28 & 57,14 & 52,20 & 51,58 & 54,66 & 10,70 \\
\hline
\end{tabular}

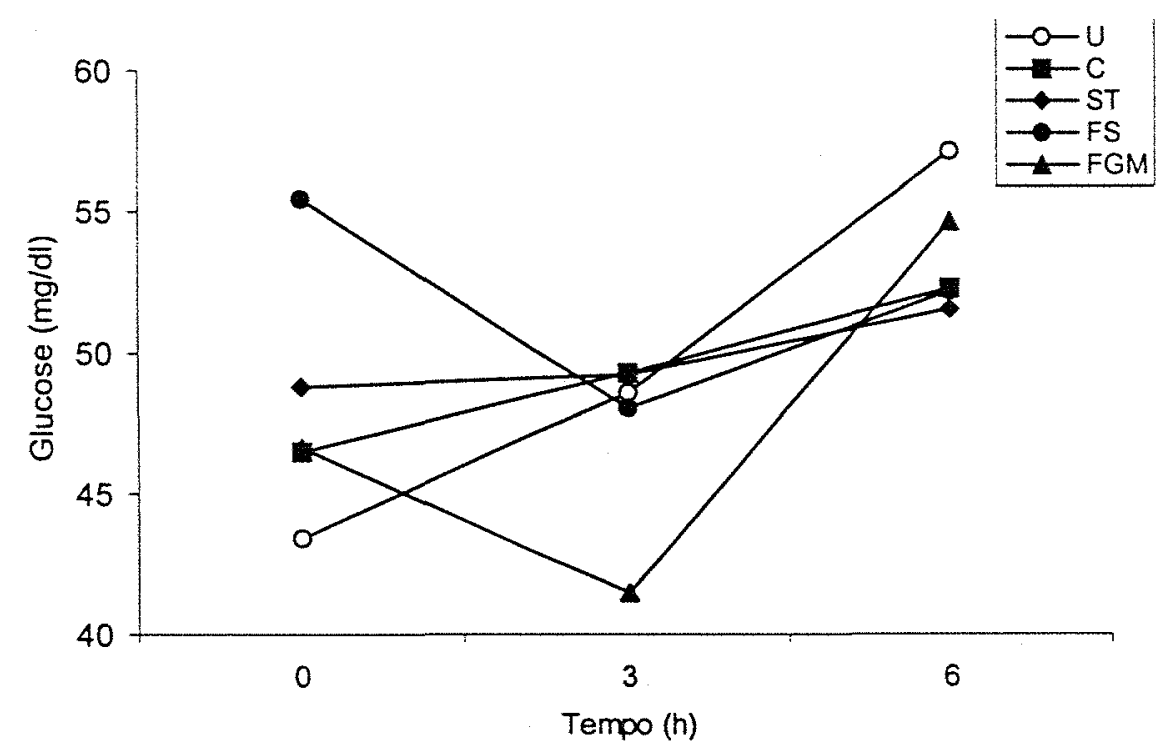

Figura 13. Efeito de fonte protéica sobre a concentração de glucose plasmática cada tempo de coleta. 


\section{CONCLUSÕES}

Para vacas produzindo ao redor de 26 a $28 \mathrm{~kg}$ de leite/d não houve benefício em se aumentar o teor de proteína bruta da dieta de $13,4 \%$ para $16,5 \%$, seja via fontes ricas em nitrogênio não protéico, proteína degradável no rúmen ou ricas em proteína não degradável no rúmen, pois a ingestão de matéria seca, produção de leite, eficiência alimentar, digestibilidade da matéria seca, da matéria orgânica, do amido e da fibra em detergente neutro não foram alterados.

Estes resultados indicam que as recomendações do NRC (1988) para os teores de proteína bruta e de proteína não degradável no rúmen em dietas para vacas produzindo ao redor de 26 a $28 \mathrm{~kg} / \mathrm{d}$ são adequadas.

O processo de tostagem provavelmente afetou a proteína da soja, pois - uso de soja tostada reduziu a digestibilidade da proteina bruta e a porcentagem de proteína do leite.

Os parâmetros ruminais provavelmente estão mais associados ao teor de matéria orgânica fermentável no rúmen do que à porcentagem de proteína degradável no rúmen, pois o $\mathrm{pH}$ e a produção de ácidos graxos voláteis não foram alterados por teor e fonte de proteína.

Apesar da substituição parcial de farelo de soja por uréia em dieta a base de silagem de milho e milho floculado (360 g/L) aumentar a concentração de amônia no rúmen, refletindo em aumento na concentração de uréia plasmática, a concentração de glucose plasmática não foi alterada. 


\section{REVISÃO BIBLIOGRÁFICA}

ANNEXSTAD, R.J.; STERN, M.D.; OTTERBY, D.E.; LINN, J.G.; HANSEN, W.P. Extruded soybeans and corn gluten meal as supplemental protein sources for lactating dairy catle. Journal of Dairy Science, v. 70,n. , p. 814-22, 1987.

ARIELI, A.; SHABI, Z.; BRUCKENTAL, I.; TAGARI, H.; AHARONI, Y.; ZAMWELL, S.; VOET, $H$. Effect of degradation of organic matter and crude protein on ruminal fermentation in dairy cows. Journal of Dairy Science, v. 79, n. , p. 1774-80, 1996.

ARMENTANO, L.E.; BERTICS, S.J.; DUCHARME, G.A. Response of lactating cows to methionine or methionine plus lysine added to high protein diets based on alfafa and heated soybeans. Journal of Dairy Science, v. 80 , p. 1194-99, 1997.

A.O.A.C. Association of Official Analytical Chemists. Official Methods of Analysis. 12. Ed., Washinton, D.c., 1990.

BAKER, L.D.; FERGUSON, J.D.; CHALUPA, W. Response in urea and true protein of milk to different protein feeding schemes for dairy cows. Journal of Dairy Science, v. 78, p. 2424-34, 1995. 
BAKER, J.G.; TOMLINSON, J.E.; MCGEE, W.H. The evaluation of soybean meal, roasted whole soybeans or whole cottonseed as a concentrate ingredient for lactating dairy cows. Journal of Dairy Science, v. 68:Supplement 1, p. 258, 1985.

BATEMAN, T.G.; MARSHAL, R.T.; BELYEA, R.L.; KERLEY, M.S.; SPAIN, J.N. Comparison of rumen potected methionine and lysine on blood meal and fish meal as protein supplements for early lactation in Holstein cows. Journal of Dairy Science, v. 77:Supplement 1, p. 91, 1994.

BERNARD, J.K.; DOWLEN, H.H.; QUIGLEY, J.D. III; BAXTER, H.D.; LAMAR, K.H.; JOHNSON, D.L. Effect of feeding raw or roasted whole soybens with or whithout niacin supplementation to Jersey cows during early lactation. Journal of Dairy Science, v. 75:Supplement 1, p. 299, 1992.

BERZAGHI, P.; POLAN, C.E. Effect of undegradable protein on milk production and milk composition when cows were fed alfafa haylage based diet. Journal of Dairy Science, v. 74:Supplement 1, p. 216 (Abstr), 1991.

BRODERICK, G.A. Relative value of solvent and expeller soybean meal for lactating dairy cows. Journal of Dairy Science, v. 69, p. 2958-58, 1986.

BRODERICK, G.A.; CRAIG, W.M.; RICKER, D.B. Urea versus true protein as supplement for lactating dairy cows fed grain plus mixtures of alfafa and corn silages. Journal of Dairy Science, v. 76, p. 2266-74, 1993.

CALSAMIGLIA, S.; STERN, M.D. A three-step in vitro procedure for estimating intestinal digestion of protein in ruminants. Journal of Dairy Science, $v$. 73, p. 1450-65, 1995. 
CASPER, D.P.; SCHINGOETHE, D.J. Evaluation of urea and dried whey in diets of cows during early lactation. Journal of Dairy Science, v. 69, p. 1346-54, 1986.

CASPER, D.P.; SCHINGOETHE, D.J.; EISENBEISZ, W.A. Response of early lactation dairy cows fed diets varying in source of nonstructural carboydrate and crud protein. Journal of Dairy Science, v. 73, p. 1039$50,1990$.

CHAN, S.C.; HUBER, J.T.; THEURER, C.B.; WU, Z.; CHEN, K.H.; SIMAS, J.M. Effects of supplemental fat and protein sources on ruminal fermentation and nutrient flow to the duodenum in dairy cows. Journal of Dairy Science, v. 80, p. 152, 1997.

CHANEY, A.L.; MARBACH, E P. Modified reagents for determination of urea and amonia. Clinical Chemistry, v.8, p.130-37, 1962.

CHANDLER, P.T. Achievement of optimum amino acid balance possible. Feedstuffs, v.61, n.26, p. 14 e 25, 1989. 
CHEN, K.H.; HUBER, J.T.; THEURER, C.B.; ARMSTRONG, D.V.; WANDERLEY, R.C.; SIMAS, J.M.; CHAN, S.C.; SULLIVAN, J.L. Effect of protein quality and evaporative cooling on lactational performance of Holstein cows in hot weather. Journal of Dairy Science, v. 76, p. 84925, 1993.

CHEN, K.H.; HUBER, J.T.; THEURER, C.B.; SIMAS, J.M.; SANTOS, F.P.; CHAN, S.C.; SWINGLE, R.S. Effect of sbstituiting steam-flaked sorghum for concentrate, on lactation and digestion in dairy cows. Journal of Dairy Science, v. 78, p. 362-67, 1995.

CHOUINARD, P.Y.; GIRARD, V.; BRISSON, G.J. Performance and profiles of milk fatty acids of cows fed full fat, heat-treated soybeans using various processing methods. Journal of Dairy Science, v. 80, p. 334-42, 1997.

CLARK, J.H. Lactational responses to postruminal administration of proteins and amino acdis. Journal of Dairy Science, v. 58, p. 1178-97, 1975.

CLARK, J.H.; KLUSMEYER, T.H.; CAMERON, M.R. Microbial protein synthesis and flows of nitrogen fractions to the duodenum of dairy cows. Journal of Dairy Science, v. 75, p. 2304-23, 1992.

CLARK, J.H.; MURPHY, M.R.; CROOKER, B.A. Supplying the protein needs of dairy cattle from by-product feeds. Journal of Dairy Science, v. 70, p. 1092-109, 1987. 
COZZI, G.; POLAN, C.E. Corn gluten meal or dried brewers grains as partial replacement for soybean meal in the diet of holtein cows. Journal of Dairy Science, v. 77, p. 825-34, 1994.

DHIMAN, T.R.; KOREVAAR, A.C.; SATTER, L.D. Particle size of roasted soybeans and the effect on milk production of dairy cows. Journal of Dairy Science, v. 80, p. 1722-27, 1997.

FALDET, M.A.; SATTER, L.D. Feeding heat-treated full fat soybeans to cows in early lactation. Journal of Dairy Science, v. 74, p. 3047-54, 1991.

FENTON, T.W.; FENTON. Na improved procedure for determination of chromic oxide in feed and feces. Canadian Journal Animal Science, v.59, p. 631-34, 1979.

FALDET, M.A.; VOSS, V.L.; BRODERICK, G.A.; SATTER, L.D. Chemical, in vitro, and in situ evaluation of heat-treated spybean protein. Journal of Dairy Science, v. 74, p. 2548-54, 1991.

GRUMMER, R.R.; LUCK, M.L.; BARMORE, J.A. Lactational performance of dairy cows fed raw soybeans, with or without animal by-product proteins, or roasted soybeans. Journal of Dairy Science, v. 77, p. 1354-, 1994.

GRUMMER, R.R.; SLARK, K.; BERTICS, S.J.; LUCK, M.L.; BARMORE, J.A. Soybeans versus animal sources sources of rumen-undegradable protein and fat for early lactation dairy cows. Journal of Dairy Science, v. 79, p. 1809-16, 1996. 
HIGGINBOTHAM, G.E.; TORABI, M.; HUBER, J.T. Influence of dietary protein concentration and degradability on performance of lactating cows during hot environmental temperatures. Journal of Dairy Science, v. 72, p. 2554-64, 1989.

JOHNSON, C.O.L.E.; HUBER, J.T.; KING, K.J. Storage and utilization of brewers wet grains in diets for lactating dairy cows. Journal of Dairy Science, v. 70, p. 98-107, 1987.

KEERY, C.M.; AMOS, H.E. Effects of source and level of undegraded intake protein on nutrient use and performance of early lactationcows. Journal of Dairy Science, v. 76, p. 499-513, 1993.

KING, K.J.; HUBER, J.T.; SADIK, M.; BERGEN, W.G.; GRANT, A.L.; KING, V.L. Influence of dietary protein sources on the amino acid profiles available for digestion and metabolism in lactating cows. Journal of Dairy Science, v. 73, p. 3208-16, 1990.

KLUSMEYER, T.H.; MCCARTHY Jr, R.D.; CLARCK, J.H.; NELSON, D.R. Effects of source and amount of protein on ruminal fermentation and passage of nutrients to the small intestine of lactating cows. Journal of Dairy Science, v. 73, p. 3526-37, 1990.

KNAPP, D.M.; GRUMMER, R.R.; DENTINE, M.R. The response of lactating dairy cows to increasing levels of whole roasted soybeans. Journal of Dairy Science, v. 74, p. 2563-72, 1991. 
LINES, L.W.; WEISS, W.P. Use of nitrogen from ammoniated alfafa hay, urea, soybean meal and animal protein meal by lactating cows. Journal of Dairy Science, v. 79, p. 1992-99, 1991.

MABJEESH, S.J.; ARIELI, A.; BRUCKENTAL, I.; ZAMWELL, S.; TAGARI, H. Effect of type of protein supplementation on duodenal amino acid flow and absorption in dairy cows. Journal of Dairy Science, v. 79, p. $1792-$ $801,1996$.

MATTHEWS, J.C.; WEBB Jr., K.E. Absortion of L-Carnisine, L-Methionine, and L-Methionyglycine by isolated sheep ruminal and omasal epithelial tissue. Journal of Animal Science, v. 73, p. 3464-, 1995.

MCNIVEN, M.A.; ROBINSON, P.H.; MACLEOD, J.A. Evaluation of a new high protein variety of soybean as a source of protein and energy for dairy cows. Journal of Dairy Science, v. 77, p. 2605-13, 1994.

MIELKE C.D. e SCHINGOETHE D.J. Heat-treated soybeans for lactating cows. Journal of Dairy Science, v. 64, p. 1579-, 1981.

MOHAMED, O.E.; SATTER, L.D.; GRUMMER, R.R.; EHLE, F.R. Influence of dietary cottonseed and soybean on milk production and composition. Journal of Dairy Science, v. 71, p. 2677-, 1988.

MOORE, J.A.; POORE, M.H.; ECK, T.P.; SWINGLE, R.S.; HUBER, J.T.; ARANA M.J. Sorghum grain processing and buffer additions for early lactation dairy cows. Journal of Dairy Science, v. 75, p. 3465-, 1992. 
NATIONAL RESEARCH COUNCIL. Ruminant Nitrogen Usage, Washington, National Academy of Science, 1985.

NATIONAL RESEARCH COUNCIL. Nutrient Requeriments of Dairy Cattle, 6 ed., Washington, National Academy of Science, 1988.

NIANOGO, A.J.; AMOS, H.E.; FROETSCHEL, M.A.; KEERY, C.M. Dietary fat, protein degradability, and calving season: effects on nutrient use and performance of early lactation cows. Journal of Dairy Science, v. 74, p. 2243-55, 1991.

NOCEK, J.E.; HART, S.P.; POLAN, C.E. Rumen ammonia concentration as influenced by storage time, freezing and thawing, acid preservative, and method of ammonia determination. Journal of Dairy Science, v. 70, p. 601-7, 1987.

NUSSIO, L.G. Effects of levels and ruminally degradable starch on performance, ruminal parameters and in situ degradation of nutrients in lactating dairy cows fed sorghum diets. Tucson, 1997. 139p. Dissertação (PhD)- University of Arizona.

POORE, M. H.; MOORE, J. A.; SWINGLE, R. S.; ECK, T. P.; BROW, W. H. Wheat straw or alfafa hay in diets with $30 \%$ neutral detergent fiber for lactating Holstein cows. Journal of Dairy Science, v. 74, p.3152, 1991.

PALMQUIST, D.; CONRAD, $H$. Origin of plasma fatty acids in lactating cows fed high fat diets. Journal of Dairy Science, v. 54, p. 1025, 1971. 
PIEPENBRINK, M.S.; SCHINGOETHE, D.J. Ruminal degradation, amino acid composition, and estimated intestinal digestibilities of four protein supplements. Journal of Dairy Science, v. 81, p. 454-61, 1998.

PLASCENCIA, A.; ZINN, R.A. Influence of flake density on the feeding value of steam-processed corn in diets for lactating cows. Journal Animal Science, v. 74, p. 310-16, 1996.

POLAN, C.E.; CUMMIS, K.A.; SNIFFEN, C.J.; MUSCATO, T.V.; VICINI, J.L.; CROOKER, B.A.; CLARK, J.H.; JOHNSON, D.G.; OTTERBY, D.E.; GUILLAUME, B.; MULLER, L.D.; VARGA, G.A.; MURRAY, R.A.; PEIRCE-SANDNER, S.B. Response of cows to supplemental rumenprotected forms of methionine and lysine. Journal of Dairy Science, $v$. 74, p. 2997-3013, 1991.

PRICE, S.G.; SATTER, L.D.; JORGENSEN, N.A. Dehydrated alfafal in dairy cow diets. Journal of Dairy Science, v. 71, p. 727-36, 1988.

REDDY, P.V.; MORRIL, J.L.; NAGARAJA, T.G. Release of free fatty acids from raw or processed soybeans and subsequent effects on fiber digestibilities. Journal of Dairy Science, v. 77, p. 3410-3416, 1994.

ROBERTSON, J.B.; VAN SOEST, P.J. The detergent system of analysis and its application to human foods. In: Jamen, W.P.T. e Theander, O. Analysis of Dietary Fiber in Food. New York: Marcel Dekker, 1981. V.3, p.123.

ROBINSON, P.H.; MCQUEEN, R.E.; BURGESS, P.L. Influence of rúmen undegradable protein levls on feed intake and milk production of dairy cows. Journal of Dairy Science, v. 74, p. 1623-31, 1991. 
RULQUIN, H.; VERITÉ, R. Amino acid nutrition of dairy cows: Productive effects and animal requirements. In: Garnsworthy, P.C. e Cole, D.J.A. Recent Advances in Animal Nutrition. Nottingham Univ. press, 1993. p. 5577.

RUSSEL, J.B.; O'CONNOR, J.D.; FOX, D.J.; VAN SOEST, P.J.; SNIFFEN, C.J. A net carbohydrate and protein system for avaluating cattle diets: I Ruminal fermentation. Journal Animal Science, v. 70, p. 3551-61, 1992.

SANTOS, F.A.P. Effect of sorghum grain processing and protein source on performance and nutrient utilization by lactating dairy cows. Tucson, 1996. 140p. Dissertação (PhD)- University of Arizona.

SANTOS, F.P.; HUBER, J.P. Quality of bypass proteins fed to high-producing cows is important. Feedstuffs, v. 68, n.34, p.12-15, 1996.

SANTOS, F.A.P.; HUBER, J.T.; THEURER, C.B.; SANTOS, J.; NUSSIO, L.G.; SIMAS, J.M.; YU, P.; AQUINO, J.; MENA, H.; TARAZON, M.; KEISTER, $Z$.; SOUZA, F. Response of high producing dairy cows to different protein sources when fed steam-flaked sorghum diets. Journal of Dairy Science, v. 78:Supplement 1, p. 294, 1995. 
SANTOS, F.A.P.; HUBER, J.T.; THEURER, C.B.; SWINGLE, R.S.; SIMAS, J.M.; CHEN, K.H.; YU, P. Milk yield and composition of lactating cows fed steam-flaked sorghum and graded concentrations of ruminally degradable protein. Journal of Dairy Science, v. 81, p. 215-20, 1998.

SAS Users Guide: Statistics, Version 5 Edition. 1991. SAS Inst., Inc., Cary, NC.

SATTER, L.D.; SLYTER, L.L. Effect of ammonia concentration on rumen microbial protein production in vitro. British Journal Nutrition, v. $32, \mathrm{n}$. 2, p. 199-208, 1974.

SCHWAB, C.G.; SATTER, L.D.; CLAY, A.B. Response of lactating cows to abomasal infusion of amino acids. Journal of Dairy Science, v. 59, p. 1254-70, 1976.

SCHWAB, C.G. Optimizing amino acid nutrition for optimum yields of milk and milk protein. In: CONF., DEPT. ANIM. SCl., Univ. Arizona, Tucson, 1994. Proc. southwest nutr. manage. p. 114-129.

SCHWAB, C.G.; BOZAK, C.K.; WHITEHOUSE, N.L.; MESBAH, M.M.A. Amino acid limitation and flow to duodenum at four stages of lactation. 1. Sequence of lysine and methionine limitation. Journal of Dairy Science, v. 75, p. $3486-502,1992 a$.

SCHWAB, C.G.; BOZAK, C.K.; WHITEHOUSE, N.L.; OLSON, V.M. Amino acid limitation and flow to duodenum at four stages of lactation. 2.Extent of lysine limitation. Journal of Dairy Science, v. 75, p. 3503-18, 1992b. 
SCHINGOETHE, D.J. Balancing the dairy cow amino acid needs. Animal Feed Science Technologi, v. 60, p. 153-60, 1996.

SCHINGOETHE, D.J. Protein quality and amino acid supplementation in dairy cattle. Prc. Southwest Nutr. Manage. Conf., Dept. Anim. Sci., Univ. Arizona, Tucson, pp. 101-106, 1991.

SCHINGOETHE, D.J.; CASPER, C.P.; YOUNG, C.; ILLG, D.J.; SOMMERFELDT, J.L.; MUELLER, C.R. Lactational response to soyben meal, heated soyben meal, and extruded soybeans with ruminally protected methionine. Journal of Dairy Science, v. 71, p. 173-80, 1993.

SCOTT, T.A.; COMBS, D.K.; GRUMMER, R.R. Effects of roasting, extrusion, and particle size on the feeding value of soybeans for dairy cows. Journal of Dairy Science, v. 74, p. 2555-, 1991.

SIMAS, J.M. Processamento de grãos para rações de vacas leiteiras. In: Simpósio sobre produção animal, 9ำ. Piracicaba, 1996. Confinamento de bovinos. Piracicaba: FEALQ, 1997. p. 7-32.

SIMAS, J.M.C. Effect of sorghum grain processing and fat supplementation on performance and nutrient utilization in lactating dairy cows. PhD dissertation. The University of Arizona. 1995.

SNIFFEN, C.J.; O'CONNOR, J.D.; VAN SOEST, P.J.; FOX, D.J.; RUSSEL, J.B. A net carbohydrate and protein system for avaluating cattle diets: II Carbohydrate and protein availability. Journal Animal Science, v. 70, p. 3562-77, 1992. 
SNIFFEN, C.J.; ROBINSON, P.H. Microbial growth and flow as influenced by dietary manipulations. Journal of Dairy Science, v. 70, p. 425-29, 1987.

SOCHA, M.T.; SATTER, L.D. Feeding of heat-processed whole soybeans to primiparous and multiparous cows. Journal of Dairy Science, $v$. 74:Supplement 1, p. 251, 1991.

STERN, M.D.; SANTOS, K.A.; SATTER, L.D. Protein degradation in rúmen and amino acid absorption in small intestine of lactating dairy catle fed-heated whole soybeans. Journal of Dairy Science, v. 68, p. 45-56, 1985.

TAYLOR, R.B.; HUBER, J.T.; GOMEZ-ALARCON, R.A. Influence of degradability and evaporative cooling on performance of dairy cows during hot environmental temperatures. Journal of Dairy Science, v. 74 , p. $243-49,1991$.

THEURER, C.B. Grain processing effects on starch utilization by ruminants. Journal Animal Science, v. 63, p. 1649-62, 1986.

TICE, E.M.; EASTRIDGE, M.L.; FIRKINS, J.L. Raw soybeans and roasted soybeans of different particle sizes. 1. Digestibility and utilization by lactating cows. Journal of Dairy Science, v. 76, p. 224-29, 1993.

TICE, E.M.; EASTRIDGE, M.L.; FIRKINS, J.L. Raw soybeans and roasted soybenas of diferent particle sizes. 2. Fatty acid utilization cows. Journal of Dairy Science, v. 77, p. 166-180, 1994.

VIRTANEN, A.I. Milk production of cows on protein-free feeds. Science, v. 153, p.1603-14, 1966. 
VOSS, V.L.; STEHR, D.; SATTER, L.D.; BRODERICK, G.A. Feeding lactating dairy cows proteins resistant to ruminal degradation. Journal of Dairy Science, v. 71, p. 2428-39, 1988.

WALTZ, D.M.; STERN, M.D.; ILLG, D.J. Effect of ruminal protein degradation of blood meal and feather meal on the intestinal amino acid supply to lactating cows. Journal of Dairy Science, v. 72, p. 1509-18, 1989.

WEBB Jr., K.E.; DIRIENZO, D.B.; MATTHEWS, J.C. Symposium: Nitrogen metabolism and amino acid nutrition in dairy catle. Journal of Dairy Science, v. 76, p. 351-, 1993.

WEBB Jr., K.E.; MATTHEWS, J.C.; DIRIENZO, D.B. Peptide absorpition: A review of concepts and future perpectives. Journal of Dairy Science, $v$. 70 , p. 3248-54, 1992.

WHEELER, J.G.; AMOS, H.E.; FROETSCHEL, M.A.; COOMER, J.C.; MADDOX, T.; FERNANDEZ, J.M. Responses of early lactation cows fed winter and summer annual forages and undegradable intake protein. Journal of Dairy Science, v. 78, p. 2767-81, 1995.

WINDSCHITL, P.M.; STERN, M.D. Evaluation of calcium lignosulfonate-treated soybean meal as source of rúmen protected protein for dairy cattle. Journal of Dairy Science, v. 71, p. 3310-22, 1988.

WOHLT, J.E.; CHMIEL, S.L.; ZAJAC, P.K.; BACKER, L.; BLETHEN, D.B.; EVANS, J.L. Dry matter intake, milk yield and composition, and nitrogen use in holstein cows fed soybean, fish, or corn gluten meals. Journal of Dairy Science, v. 74, p. 1609-22, 1991. 
YU, P.; HUBER, J.T.; THEURER, C.B.; CHEN, S.C.; CHEN, K.H.; WU, Z.; SIMAS, J.; SANTOS, F.; FONTES, C.; VARELA, J.; GHENNIA, J.A. Effect of fedding Amaferm during hot weather on performance od dairy cows fed diets of steam-flaked or steam-roled corn. Journal of Dairy Science, v. 77:Supplement 1, p. 383, 1994. 